\title{
Bizarre fossil beaked whales (Odontoceti, Ziphiidae) fished from the Atlantic Ocean floor off the Iberian Peninsula
}

\author{
Giovanni BIANUCC \\ Università di Pisa, Dipartimento di Scienze della Terra, \\ via S. Maria, 53, I-56126 Pisa (Italy) \\ bianucci@dst.unipi.it
}

Ismael MIJÁN

Sociedade Galega de Historia Natural, Apdo. 356, S-15480 Ferrol (Spain) ismaelmijan@edu.xunta.es

Olivier LAMBERT Muséum national d'Histoire naturelle, Département Histoire de la Terre, 57 rue Cuvier, F-75231 Paris cedex 05 (France) and Institut royal des Sciences naturelles de Belgique,

Département de Paléontologie, 29 rue Vautier, B-1000 Brussels (Belgium) olivier.lambert@naturalsciences.be

Klaas POST

Natuurhistorisch Museum Rotterdam, P.O. Box 23452, NL-3001 Rotterdam (The Netherlands) klaaspost@fishcon.nl

Octávio MATEUS

Universidade Nova de Lisboa, CICEGe, Faculdade de Ciências e Tecnologia, FCT, 2829-516 Caparica (Portugal) and Museu da Lourinhã, Rua João Luís de Moura, 95, P-2530 Lourinhã (Portugal) omateus@fct.unl.pt

Bianucci G., Miján I, Lambert O., Post K. \& Mateus O. 2013. - Bizarre fossil beaked whales (Odontoceti, Ziphiidae) fished from the Atlantic Ocean floor off the Iberian Peninsula. Geodiversitas 35 (1): 105-153. http://dx.doi.org/10.5252/g2013n1a6

\begin{abstract}
Forty partial fossil skulls belonging to beaked whales (Cetacea, Odontoceti, Ziphiidae) were collected by trawling and long-line fishing on Neogene (probably Late Early to Middle Miocene) layers of the Atlantic floor off the coasts of Portugal and Spain (Asturias and Galicia). The systematic study of the most diagnostic Iberian specimens, those preserving the rostrum and the dorsal part of the cranium, led to the recognition of two new genera (Globicetus n. gen.
\end{abstract}


KEY WORDS

Cetacea,

Odontoceti,

Ziphiidae,

Neogene,

Miocene,

Portugal, Spain, phylogeny, skull morphology, new genera, new species. and Imocetus n. gen.) and four new species (Choneziphius leidyi n. sp., G. hiberus n. gen., n. sp., I. piscatus n. gen., n. sp., and Tusciziphius atlanticus n. sp.). Based on the matrix of a previous work, the phylogenetic analysis places all the new taxa in the subfamily Ziphiinae Gray, 1850. More fragmentary specimens are tentatively referred to the genera Caviziphius Bianucci \& Post, 2005 and Ziphirostrum du Bus, 1868. Among these new ziphiids, extremely bizarre skull morphologies are observed. In $G$. hiberus n. gen., n. sp. the proximal portion of the rostrum bears a voluminous premaxillary spheroid. In T. atlanticus $\mathrm{n}$. $\mathrm{sp}$. a medial premaxillary bulge is present on the rostrum; together with asymmetric rostral maxillary eminences at the rostrum base, this bulge displays various degrees of elevation in different specimens, which may be interpreted as sexual dimorphism. Specimens of I. piscatus n. gen., n. sp. bear two sets of even crests: spur-like rostral maxillary crests and longitudinal maxillary crests laterally bordering a wide and long facial basin. A preliminary macroscopic observation of these elements indicates very dense bones, with a compactness comparable with that of cetacean ear bones. Questioning their function, the high medial rostral elements (the premaxillary spheroid of G. hiberus n. gen., n. sp. and the medial bulge of T. atlanticus $\mathrm{n}$. sp.) remind the huge rostral maxillary crests of adult males of the extant Hyperoodon ampullatus (Forster, 1770). In the latter, the crests are very likely related to head-butting. However, they are made of much more spongy bone than in the fossil taxa studied here, and therefore possibly better mechanically suited for facing impacts. Other interpretations of these unusual bone specializations, related to deep-diving (ballast) and echolocation (sound reflection), fail to explain the diversity of shapes and the hypothetical sexual dimorphism observed in at least part of the taxa. The spur-like rostral maxillary crests and long maxillary crests limiting the large facial basin in I. piscatus n. gen., n. sp. and the excrescences on the maxilla at the rostrum base in Choneziphius spp. are instead interpreted as areas of origin for rostral and facial muscles, acting on the nasal passages, blowhole, and melon. From a palaeobiogeographic point of view, the newly described taxa further emphasize the differences in the North Atlantic (including Iberian Peninsula) and South African Neogene ziphiid faunal lists. Even if the stratigraphic context is poorly understood, leaving open the question of the geological age for most of the dredged specimens, these differences in the composition of cold to temperate northern and southern hemisphere fossil ziphiid faunas may be explained by a warm-water equatorial barrier.

\section{RÉSUMÉ}

Étranges baleines à bec fossiles (Odontoceti, Ziphiidae) pêchées sur le fond de l'Océan Atlantique au large de la péninsule ibérique.

Quarante crânes partiels fossiles de baleines à bec (Cetacea, Odontoceti, Ziphiidae), pêchés au chalut et à la palangre sur des couches du Néogène (probablement fin du Miocène inférieur à Miocène moyen) du fond de l'Atlantique au large des côtes du Portugal et d'Espagne (Asturies et Galice), sont signalés. L'étude sytématique des spécimens ibériques les plus diagnostiques, ceux dont le rostre et la partie faciale sont préservés, a permis la reconnaissance de deux nouveaux genres (Globicetus n. gen. et Imocetus n. gen.) et de quatre nouvelles espèces (Choneziphius leidyi n. sp., G. hiberus n. gen., n. sp., I. piscatus n. gen., n. sp. et Tusciziphius atlanticus n. sp.). Sur la base de la matrice d'un travail précédent, l'analyse phylogénique positionne l'ensemble des nouveaux taxons 
dans la sous-famille Ziphiinae Gray, 1850. Des spécimens plus fragmentaires sont provisoirement attribués aux genres Caviziphius Bianucci \& Post, 2005 et Ziphirostrum du Bus, 1868. Parmi ces nouveaux ziphiidés, des morphologies extrêmement bizarres sont observées. Chez G. hiberus n. gen., n. sp., la partie proximale du rostre porte une volumineuse sphère prémaxillaire. Une crête médiale prémaxillaire est présente sur le rostre de T. atlanticus n. sp.; cette crête, de même que des éminences rostrales maxillaires asymmétriques, montre différents degrés d'élévation au sein de l'espèce, peut-être en lien avec du dimorphisme sexuel. Les spécimens d'I. piscatus n. gen., n. sp. portent deux paires de crêtes : des crêtes rostrales maxillaires en forme d'éperon et des crêtes maxillaires longitudinales bordant latéralement un long et large bassin facial. L'observation macroscopique préliminaire de ces éléments indique un os très dense, avec une compacité comparable à celle des os de l'oreille des cétacés. Au niveau de leur fonction potentielle, les éléments médians du rostre (sphère prémaxillaire de $G$. hiberus n. gen., n. sp. et crête médiane prémaxillaire de T. atlanticus $n$. sp.) rappellent les énormes crêtes maxillaires rostrales des mâles adultes de l'espèce moderne Hyperoodon ampullatus (Forster, 1770). Chez ce dernier, les crêtes sont très probablement utilisées lors de combats par coups de tête. Cependant, elles sont constituées d'un os beaucoup plus spongieux que chez les taxons fossiles étudiés ici, et donc peut-être plus aptes mécaniquement à subir des impacts. D'autres interprétations des ces spécialisations osseuses inhabituelles, liées aux plongées profondes (ballast) et à l'écholocalisation (réflexion des sons), échouent à expliquer la diversité des formes et le possible dimorphisme sexuel observé chez une partie des espèces. Les crêtes rostrales maxillaires en forme d'éperon et les longues crêtes maxillaires limitant le grand bassin facial d'I. piscatus n. gen., n. sp. et les excroissances sur le maxillaire à la base du rostre de Choneziphius spp. sont, elles, interprétées comme des régions

MOTS CLÉS Cetacea, Odontoceti,

Ziphiidae,

Néogène,

Miocène,

Portugal,

Espagne, phylogénie, morphologie crânienne, genres nouveaux, espèces nouvelles. d'origine pour des muscles rostraux et faciaux, agissant sur les conduits nasaux, l'évent et le melon. D’un point de vue paléobiogéographique, les nouveaux taxons confirment les différences de contenu des listes fauniques de ziphiidés néogènes de l'Atlantique Nord (incluant la péninsule ibérique) et de l'Afrique du Sud. Malgré le contexte stratigraphique peu précis, laissant ouverte la question de l'âge géologique de la plupart des spécimens pêchés sur le fond de la mer, ces différences dans la composition des faunes de ziphiidés fossiles des régions froides à tempérées des hémisphères nord et sud pourraient être expliquées par la présence d'une barrière d'eau équatoriale chaude.

\section{INTRODUCTION}

Including at least 21 extant species (Dalebout et al. 2002), beaked whales (Ziphiidae Gray, 1850) are the second most species-rich modern cetacean family, following the Delphinidae Gray, 1821. In addition to dental reduction, these deep-diving, generally teuthophagous animals are characterized by various skull specializations, some of these specializations being sexually dimorphic, that place them as one of the most peculiar odontocete groups and lead to contrasted functional interpretations (Heyning 1984; Buffrénil et al. 2000; MacLeod 2002; Lambert et al. 2011). For a long time the fossil record of ziphiids was scarce compared to its high present diversity. Even now, the number of fossil species 
based on specimens from inland deposits remains small (e.g., Muizon 1984; Bianucci et al. 1994 , 2010; Lambert \& Louwye 2006; Lambert et al. 2009; Bianucci et al. 2010). However, specimens recovered from the bottom of oceans proved to be an essential source of information. Fossils, generally isolated rostra, have been reported from the South Pacific Ocean (Fordyce \& Cullen 1979; Miyazaki \& Hasegawa 1992), Indian Ocean (Robineau 1973), and Sea of Japan (Horikawa et al. 1987; Tazaki et al. 1987). Whitmore et al. (1986) also mentioned several ziphiid fossils from other deep ocean sites and analyzed in more detail the nature of these strange and strongly phosphatized skull elements.

Later Bianucci et al. $(2007,2008)$ reported eight new fossil ziphiid genera and ten new species, based on better preserved cranial material recovered from trawling activities on the ocean bottom along the South African coasts, at depths of as much as $1000 \mathrm{~m}$. Here again, the relationships with phosphorite deposits were emphasized, allowing some argument about the still problematic dating of the specimens and the high local productivity (Bianucci et al. 2007).

Following a preliminary note (Miján 2007), the present article describes a new large sample of well preserved fossil ziphiid skulls, some of them displaying unusual morphologies, recovered from the Atlantic Ocean floor off Portugal and Spain (Asturias and Galicia).

To our knowledge, the present article, together with the Miján (2007) note, represent the first scientific report of fossil ziphiids from Iberian Peninsula. Zbyszewski (1954) referred to the new species Palaeoziphius melidensis an incomplete mandible (MG5450) collected in the Tortonian of Melides (Southwest Portugal). However, the genus Palaeoziphius Abel, 1905, primarily used for the species $P$. scaldensis (du Bus, 1872), based on another isolated mandible, has been placed in Odontoceti incertae sedis by Lambert (2005). Judging from Zbyszewski's illustrations (Zbyszewski 1954: pls 1,2), the mandible from Melides does not exhibit any ziphiid character; consequently $P$. melidensis must also be referred to Odontoceti incertae sedis. The only reliable previous fossil ziphiid record from Portugal (but not from Iberian Peninsula) originates from the Archipelago of Azores and was referred to Mesopodon sp. by Estevens \& Ávila (2007).

\section{ABBREVIATIONS}

IEO

IGF Museo di Geologia e Paleontologia dell'Università di Firenze, Florence, Italy;

MG Museu Geológico, Lisboa, Portugal;

MHNUSC Museo de Historia Natural Luis Iglesias, Universidad de Santiago de Compostela, Santiago de Compostela, Spain;

ML Museu da Lourinhã, Lourinhã, Portugal;

NMB Natuurhistorisch Museum Boekenberg, Antwerp;

NMR Natuurhistorish Museum Rotterdam;

SGHN Museo da Natureza da Sociedade Galega de Historial Natural, Ferrol, Spain.

\section{MATERIAL AND METHODS}

\section{SPECIMENS AND LOCALITIES}

We examined 40 partial ziphiid skulls recovered from the sea floor off the coasts of Asturias, Galicia, and Portugal during fishing activities based on bottom set long-line and bottom trawl (Fig. 1). All the specimens were collected on the borders of the continental platform, most of them at a depth ranging between 500 and $1000 \mathrm{~m}$. Most of the specimens were kept in private collections for years; the location is precise in some cases, but more approximate in others, for two reasons: some were collected before the Global Positioning System (GPS) was widely used and fishermen are often reluctant to reveal their fishing spots. The fossils collected off the Asturias coast are from the Canyon of Avilés and other imprecise localities along the platform. The fossils collected off Galicia are from several localities, among which As Paredes, A Selva, and Cortada fishing grounds. The specimens from Portugal were found in deep water off central Portugal (Lourinhã, Peniche), south of Nazaré Canyon; the latter extends about $210 \mathrm{~km}$ westward from the coast and reaches depths near $5000 \mathrm{~m}$ in its distal part (Tyler et al. 2009). All the fossils examined are now kept in IEO, ML, MHNUSC, and SGHN.

All the fossils are strongly phosphoritized; some of them are even partly included in a phosphatic conglomerate. Fossilization and associated sediments are actually similar for fossil ziphiids trawled off the South African coasts (Bianucci et al. 2007). 


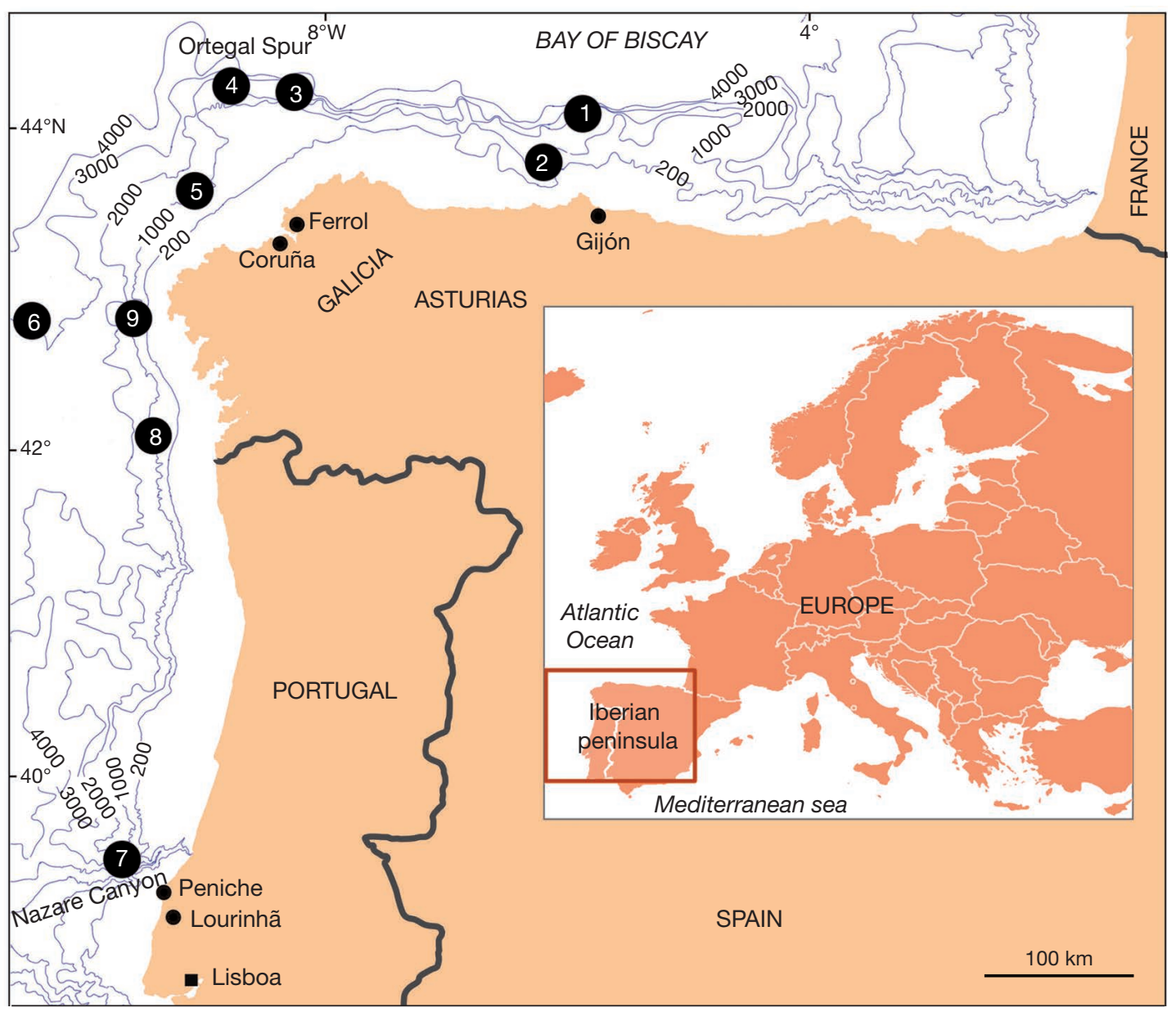

FIG. 1. - Map of Atlantic Iberian coast showing localities where fossil ziphiid skulls have been recovered by bottom set long-line and trawling: 1, Asturias continental border, imprecise location; 2, Avilés Canyon, Asturias coast; 3, As Paredes fishing ground (44¹0' $\mathrm{N}$,

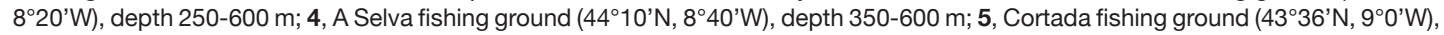
depth 400-800 m; 6, oceanographic research at $1500 \mathrm{~m}$ depth $\left(42^{\circ} 27^{\prime} \mathrm{N} 11^{\circ} 59^{\prime} \mathrm{W}\right) ; 7$, south of Nazare Canyon, imprecise location (c. $\left.39^{\circ} 18^{\prime} \mathrm{N}, 9^{\circ} 47^{\prime} \mathrm{W}\right)$; 8, escarapote fishing ground $\left(42^{\circ} 10^{\prime} \mathrm{N}, 09^{\circ} 26^{\prime} \mathrm{W}\right)$, depth 680-750 m; 9, 20 miles from Touriñán Cape (42 $50^{\prime} \mathrm{N}$, $9^{\circ} 40^{\prime} \mathrm{W}$ ), depth $1500 \mathrm{~m}$.

As commonly observed for the phosphoritized fossil beaked whale remains recovered from the sea floor (Fordyce \& Cullen 1979; Whitmore et al. 1986; Horikawa et al. 1987; Tazaki et al. 1987; Bianucci et al. 2007), all Iberian skulls are incomplete. The preserved bones are the ones that are more compact in the living ziphiids: bones from the rostrum and in some cases from the facial area of the cranium, including the vertex (Lambert et al. 2011). The more spongy and/or delicate bones forming the posteroventral portion of the braincase are generally not preserved.

Following Bianucci et al. (2007), we decided to use only those specimens that include at least the more diagnostic dorsal surface of the cranium, including the vertex, for the description of new taxa. More fragmentary fossils (e.g., isolated rostra) originating from the same geographic area are listed in the referred material only if their morphological features fully overlap those of the more complete 
specimens. Eighteen of the 40 skulls are considered as diagnostic. All these specimens are described for the first time in this article, with the exception of SGHN MA0632 and SGHN MA0644, which were previously tentatively referred to the genus Hyperoodon Lacépède, 1804 (Miján 2007).

\section{SySTEMATICS}

The systematic classification used in the following section is based on the phylogenetic analysis published by Bianucci et al. (2010), here confirmed with the addition of new taxa (see phylogenetic paragraph). Most of the described material is demonstrated to belong to the subfamily Ziphiinae Gray, 1850 , which is redefined in this article. Following Bianucci et al. (2010), this subfamily excludes Beneziphius Lambert, 2005, Messapicetus Bianucci, Landini \& Varola, 1992 and Ziphirostrum du Bus, 1868 , three genera forming, possibly together with Aporotus du Bus, 1868, a more basal clade of the ziphiid phylogenetic tree ("Messapicetus clade").

\section{SYSTEMATIC PALAEONTOLOGY}

Order CETACEA Brisson, 1762 Suborder ODONTOCETI Flower, 1867 Family ZIPHIIDAE Gray, 1850

Subfamily ZiPHIINAE Gray, 1850

Type genus. - Ziphius Cuvier, 1823.

OTHER GENERA INCLUDED. - Choneziphius Duvernoy, 1851, Globicetus n. gen., Imocetus n. gen., Izikoziphius Bianucci, Lambert \& Post, 2007, Tusciziphius Bianucci, 1997, and possibly Caviziphius Bianucci \& Post, 2005.

EMENDED DIAGNOSIS. - With the exception of Izikoziphius and Ziphius, members of the subfamily Ziphiinae differ from all other Ziphiidae in the dorsal closure of the mesorostral groove by medial sutural contact of the premaxillae extending posteriorly until the bony nares. With the exception of Choneziphius and Imocetus n. gen., they further differ from all other Ziphiidae in having very elongated nasals with the anterior tip of nasals located anterior to the premaxillary crests (ratio between length of medial suture of nasals and maximum width of nasals $>1.1$ ). They further differ from all other Ziphiidae, with the exception of the clade formed by Africanacetus
Bianucci, Lambert \& Post, 2007, Hyperoodon, Iblengesi Bianucci, Lambert \& Post, 2007, and Mesoplodon Gervais, 1850, in having the ascending process of the premaxilla concave in lateral view, with the posterodorsal portion partly overhanging the bony nares (apart from Choneziphius planirostris (Cuvier, 1823), with bony nares still visible in dorsal view). They further differ from all other Ziphiidae, except Beneziphius, Messapicetus, and Ziphirostrum, in having the left premaxillary crest anterolaterally directed.

\section{Genus Choneziphius Duvernoy, 1851}

TYPE SPECIES. - Choneziphius planirostris from southern North Sea Basin, probably Late Miocene (Lambert 2005).

OTHER SPECIES INCLUDED. - Choneziphius leidyi n. sp.

EMENDED Diagnosis. - Choneziphius differs from all other ziphiid genera in the mesorostral groove dorsally closed at the level of the antorbital notches by the joined medial margins of the premaxillary sac fossae, forming a prominent ridge posteriorly shifted to the left, and separating deeply concave anterior portions of the premaxillary sac fossae.

It also differs from the other ziphiine genera in the maxilla covered at the rostrum base with prominent excrescencies. Moreover it differs from Ziphius and Izikoziphius in the medial fusion of the premaxillae dorsally closing the mesorostral groove; from Globicetus n. gen., Imocetus n. gen., and Tusciziphius in lacking an extremely ossified trapezoidal vertex with the anterior part of the nasals contacting the premaxillary crests; from Imocetus $\mathrm{n}$. gen. in lacking a wide facial depression, a rostral maxillary spur-shaped crest, and in the location of the premaxillary foramen (not posterior to the level of the antorbital notch); from Globicetus n. gen. in lacking a large spherical medial premaxillary prominence at the rostrum base; from the possible ziphiine Caviziphius in shallower premaxillary sac fossae and in the more slender and lower right premaxillary crest.

\section{DISCUSSION}

The fossil record of Choneziphius is primarily based on several partial skulls and rostra referred to the type species $C$. planirostris. These fossils have been collected in sediments of North Sea, probably dated from the late Miocene (Belgium, Netherlands, and UK; see Lambert [2005] for bibliography and review). Lankester (1870) described C. packardi Lankester, 1870 based on an incomplete rostrum from Suffolk (UK). Leidy $(1876,1877)$ described 
C. liops Leidy, 1876 and C. trachops Leidy, 1876, based on fragmentary rostra that are now lost, from the Phosphate Beds of South Carolina (USA). While reviewing the genus Choneziphius, Lambert (2005) considered C. packardi as based on too fragmentary material to allow specific or even generic determination; he considered $C$. liops as a possibly valid species (rostrum shorter and with anterior narrowing stronger than in C. planirostris), and C. trachops as possibly conspecific with C. planirostris. According to Lambert (2005), Proroziphius macrops Leidy, 1876 and probably P. chonops Leidy, 1876, both based on fragmentary and unfortunately lost skulls from the Phosphate Beds of South Carolina, should be included in the genus Choneziphius. Whitmore \& Kaltenbach (2008) considered C. trachops as a valid taxon and assigned to this species a large rostrum collected from reworked sediments at the Lee Creek Mine, North Carolina. Although the above mentioned taxa show the apomorphies of the genus Choneziphius (at least on illustrations), we restrict these species, based on too fragmentary material, to their holotypes and consider them as incertae sedis.

\section{Choneziphius leidyi n. sp.} (Figs 2-5; Table 1)

HolOTYPE. - SGHN MA0633, partial skull including rostrum, facial area and vertex.

REFERRED SPECIMENS. — SGHN MA0640, partial skull including rostrum, facial area and vertex, Escarapote fishing ground, depth of approximately $685 \mathrm{~m}$, off the Galician coast, $42^{\circ} 08^{\prime} \mathrm{N}, 09^{\circ} 26^{\prime} \mathrm{W}$; SGHN MA0641, partial skull including posterior portion of rostrum, part of facial area and vertex, A Selva fishing ground, depth of approximately $500 \mathrm{~m}$, off the Galician coast, $44^{\circ} 10^{\prime} \mathrm{N}, 08^{\circ} 40^{\prime} \mathrm{W}$; SGHN MA0937, partial skull including rostrum and facial area, A Selva fishing ground, depth of approximately $500 \mathrm{~m}$, off the Galician coast, $44^{\circ} 10^{\prime} \mathrm{N}, 08^{\circ} 40^{\prime} \mathrm{W}$; ML 533, partial skull including rostrum and facial area, south of Nazaré Canyon, off the Portuguese coast, exact locality unknown but likely around $39^{\circ} 18^{\prime} \mathrm{N}, 9^{\circ} 47^{\prime} \mathrm{W}$; ML 1366 , fragment of skull including the left dorsal surface of the cranium with the left premaxillary crest, south of Nazaré Canyon off the Portuguese coast, exact locality unknown, but likely around $39^{\circ} 18^{\prime} \mathrm{N}, 9^{\circ} 47^{\prime} \mathrm{W}$.
ETYMOLOGY. - In honour of the American palaeontologist Joseph Leidy (1823-1891), who described several Choneziphius-like fossil ziphiids from the Mid Atlantic Coastal Plain of the USA in 1876 and 1877.

Type LOCAlity. - A Selva fishing ground, depth of approximately $500 \mathrm{~m}$, off the Galician coast, $44^{\circ} 10^{\prime} \mathrm{N}$, $08^{\circ} 40^{\prime} \mathrm{W}$.

Diagnosis. - Large species of Choneziphius differing from C. planirostris in: longer and more pointed rostrum with apex constructed of premaxillae alone; longer dorsal opening of the mesorostral groove at the apex of the rostrum; premaxillary foramina located distinctly anterior to level of prominental notch; lower maxillary crest on the supraorbital process; shallower and wider premaxillary sac fossae; less asymmetric premaxillary sac fossae; higher vertex overhanging the bony nares.

\section{DESCRIPTION}

The rostrum, although longer than in Choneziphius planirostris, exhibits the same massive appearance; in both species it is relatively narrow with a subcylindrical anterior half portion. As in C. planirostris, the facial area is wider than long. Differing from C. planirostris, the bony nares are not visible in dorsal view, being hidden by the overhanging and anteriorly projected vertex.

\section{Premaxilla}

On the complete rostra of the holotype and SGHN MA0640, the apex of the rostrum is formed by the premaxillae only, contrary to $C$. planirostris where maxilla and premaxilla both reach the apex of the rostrum. Anteriorly, the premaxillae are not fused dorsally, leaving the narrow tunnel-shaped mesorostral groove open for a length of at least $80 \mathrm{~mm}$. Such a dorsal exposure of the mesorostral groove is rarely present in the large sample of C. planirostris, and, if present, never longer than $50 \mathrm{~mm}$. For most of the rostrum length, the thick premaxillae are firmly fused at midline, with a suture remaining visible until the bony nares (as in C. planirostris).

As in $C$. planirostris, the fused premaxillae form a prominent ridge at the rostrum base, posteriorly shifted to the left and separating the deeply excavated anterior portions of the premaxillary sac fossae (the main character defining the genus Choneziphius). Each premaxillary sac fossa contains a premaxillary 


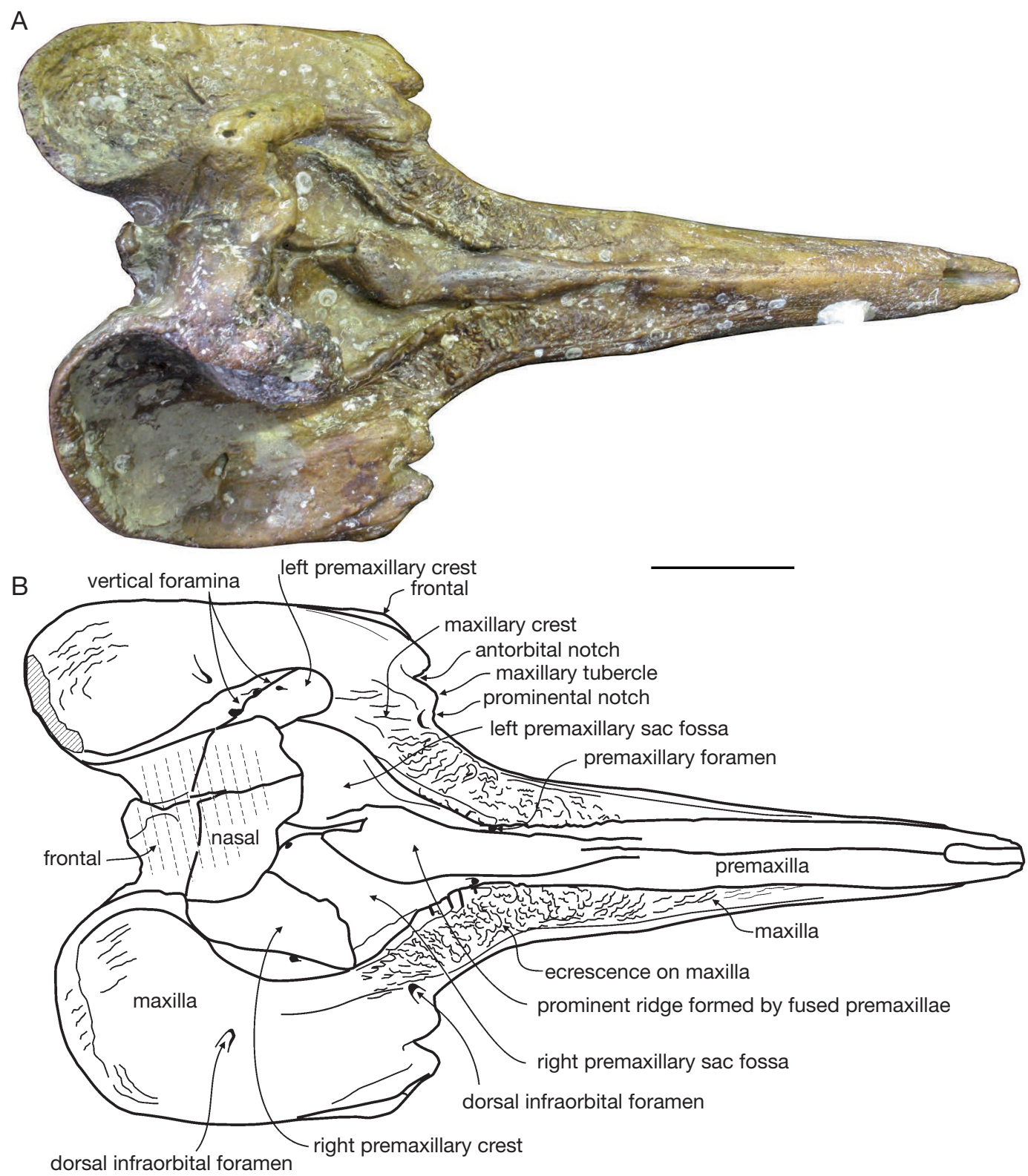

FIG. 2. - Skull of Choneziphius leidyi n. sp. (SGHN MA0633, holotype): A, dorsal view; B, corresponding line drawing. Tight parallel lines indicate a break surface; more widely spaced parallel lines indicate superficial wear. Scale bar: $10 \mathrm{~cm}$.

foramen at its anteriormost point, located well anterior to the level of the prominental notch of the maxilla (Fig. 2). In C. planirostris, the premaxillary foramen is located at, or just posterior to, the level of the prominental notch. An additional foramen is observed on the medial margin of the left premaxillary sac fossa of SGHN MA0640.

The right premaxillary sac fossa is distinctly wider than the left (ratio between maximum width of left and right fossae between 0.70 and $0.76, n=3$ ), and 


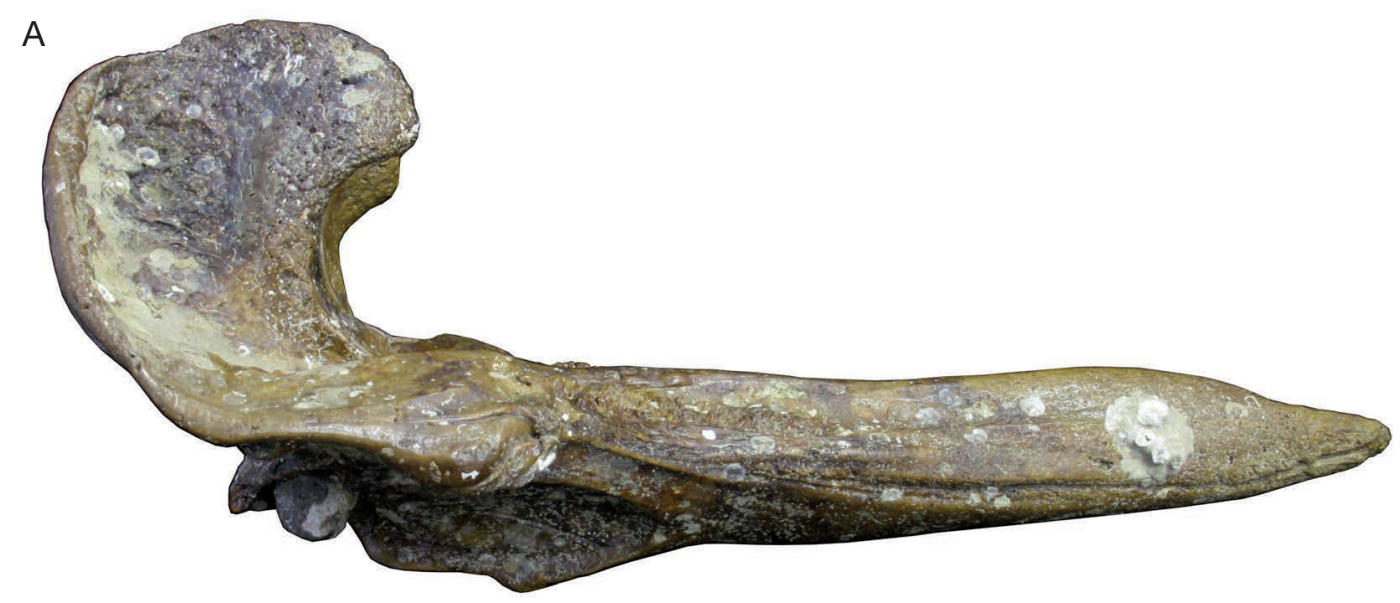

B

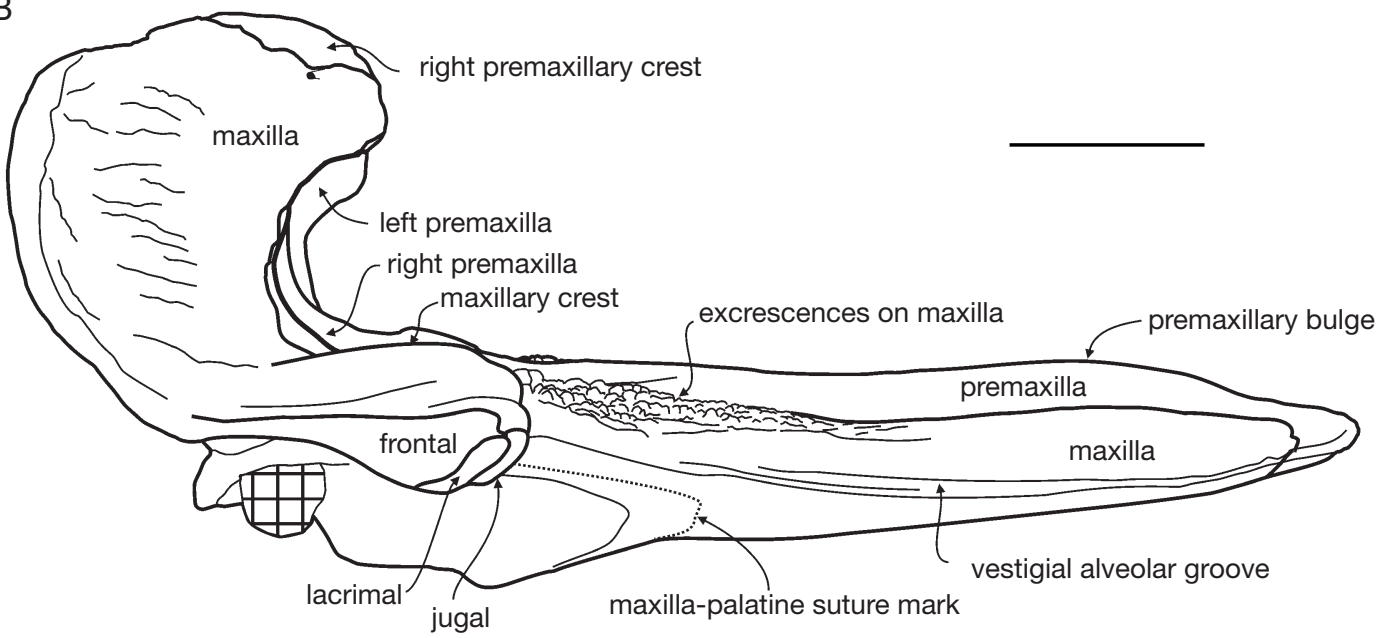

FIG. 3. - Skull of Choneziphius leidyi n. sp. (SGHN MA0633, holotype); A, lateral view; B, corresponding line drawing. Cross-hatching indicates the presence of a concretion. Scale bar: $10 \mathrm{~cm}$.

the asymmetry is therefore less pronounced than in C. planirostris (ratio between 0.48 and $0.65, \mathrm{n}=15$ ).

The anterior part of the vertex, including the ascending process of the premaxilla and the premaxillary crest, is overhanging the premaxillary sac fossae and the bony nares. This condition contrasts with $C$. planirostris, in which in lateral view the ascending process forms an angle of $\leq 90^{\circ}$ with the horizontal plane of the skull, whereas the angle is $>90^{\circ}$ in C. leidyi n. sp. The fairly slender premaxillary crest is anterolateraly directed. The right crest is distinctly larger than the left, as in C. planirostris.

\section{Maxilla}

From a roughly vertical orientation on the anterior half of the rostrum, the lateral surface of the maxilla progressively shifts to a subhorizontal dorsal surface bordered by an acute lateral margin and the thick premaxilla medially. In this part, the dorsal side of the maxilla is covered with multiple, marked excrescences. Rostra of $C$. planirostris bear similar excrescences in the same area, usually less prominent than in the known specimens of C. leidyi n. sp.

On the lateral surface of the maxilla, a marked alveolar groove is visible which sharply slopes down from its 
TABLE 1. - Measurements (in mm) on the skulls of Choneziphius leidyi $\mathrm{n}$. sp. from the Atlantic Ocean floor off the Iberian Peninsula. Abbreviations: e, estimate; +, nearly complete; - , no data.

\begin{tabular}{|c|c|c|c|c|}
\hline & $\begin{array}{c}\text { SGHN } \\
\text { MA0633 } \\
\text { (holotype) }\end{array}$ & $\begin{array}{c}\text { SGHN } \\
\text { MA0640 }\end{array}$ & $\begin{array}{c}\text { SGHN } \\
\text { MA0641 }\end{array}$ & $\begin{array}{l}\text { ML } \\
533\end{array}$ \\
\hline Rostrum length from level of antorbital notch & +503 & +495 & - & 408 \\
\hline Rostrum length from level of prominental notch & +488 & +482 & - & - \\
\hline Distance from apex of rostrum to bony nares & +588 & +585 & - & - \\
\hline Length premaxillary portion of rostrum & - & +67 & - & - \\
\hline Height of rostrum at anterior end of maxilla & - & 42 & - & - \\
\hline Width of rostrum at mid-length & 82 & 74 & - & 94 \\
\hline Width of premaxillae at mid-length of rostrum & 50 & e50 & - & - \\
\hline Height of rostrum at mid-length & 82 & 71 & - & - \\
\hline Width of rostrum base at prominental notch & 195 & - & - & - \\
\hline Width of rostrum base at antorbital notch & 252 & - & - & 205 \\
\hline Width of premaxillae at rostrum base (antorbital) & 87 & 98 & - & - \\
\hline Minimum distance between maxillae near rostrum base & 37 & - & 25 & - \\
\hline Distance rostrum base - anterior apex of palatine & e115 & e109 & - & - \\
\hline Preorbital width of skull & 354 & - & - & - \\
\hline Longitudinal distance right premaxillary foramen - rostrum base (antorbital) & 52 & 49 & - & - \\
\hline Longitudinal distance left premaxillary foramen - rostrum base (antorbital) & 63 & 52 & - & - \\
\hline Width of premaxillary sac fossae & 172 & 168 & 158 & 150 \\
\hline Width of right premaxillary sac fossa & 96 & 95 & e82 & 92 \\
\hline Width of left premaxillary sac fossa & 69 & 67 & 64 & 58 \\
\hline Width of bony nares & 73 & 80 & e81 & - \\
\hline Minimum width of right ascending process of the premaxilla & 54 & 48 & +45 & - \\
\hline Width of premaxillary crests & 178 & 170 & +155 & - \\
\hline Width of right premaxillary crest & 65 & 71 & +55 & - \\
\hline Width of left premaxillary crest & 43 & 45 & e48 & - \\
\hline Minimum distance between premaxillary crests & 83 & e74 & e60 & - \\
\hline Maximum width of nasals & e89 & e84 & e72 & - \\
\hline Minimum posterior distance between maxillae & - & 86 & 80 & - \\
\hline
\end{tabular}

uttermost point on the maxilla until approximately $9 / 5$ of the rostrum length. Within the groove SGHN MA0640 shows $12-13$ very shallow alveoli probably corresponding to vestigial teeth. A few specimens of $C$. planirostris also show traces of shallow alveoli.

From the prominent maxillary tubercle, the maxilla forms a maxillary crest on the supraorbital process, with a roughly antero-posterior direction. This crest is less prominent than in C. planirostris, a feature especially noticeable in anterior view.

Each maxilla is pierced by two dorsal infraorbital foramina, one just behind the prominental notch, and the other lateral to the vertex.

\section{Nasal}

The dorsal surface of the nasals is strongly worn in each specimen, but their outline is clearly discern- able thanks to the conspicuous sutures with the premaxillary crests, frontals, and mesethmoid, with a condition similar to $C$. planirostris. In the latter the nasals are rarely preserved, and if preserved they show a more spongy aspect than surrounding bones. This is maybe the reason why they are easily damaged and lost in Choneziphius.

\section{Frontal}

Frontals are heavily worn on the vertex of the holotype and other referred specimens. However, judging from the short distance between the ascending processes of the maxillae, they were originally transversally narrower than the nasals, a condition similar to C. planirostris. The supraorbital process of the frontal is anteriorly bordered by the lacrimal and the maxilla. 

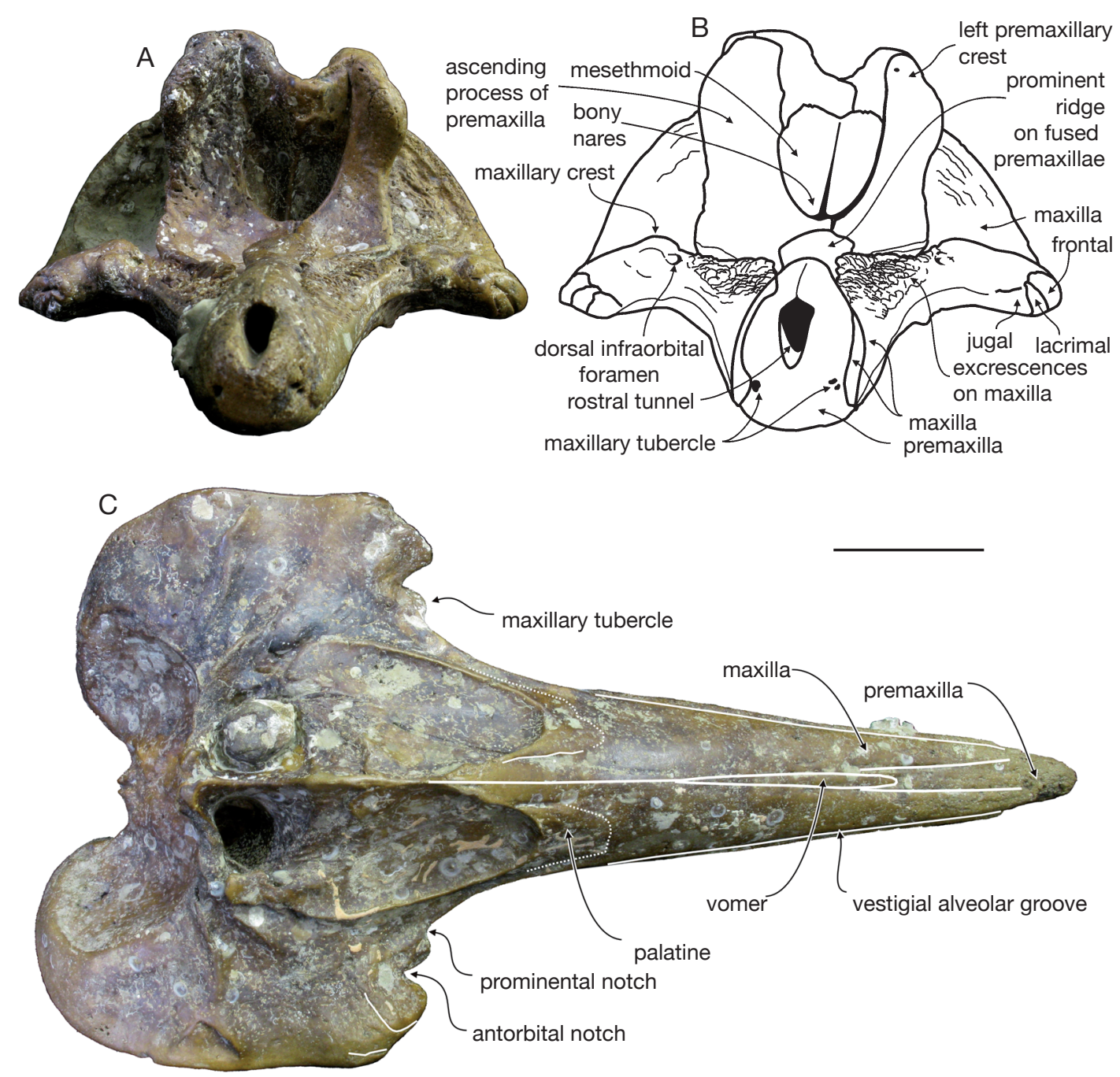

FIG. 4. - Skull of Choneziphius leidyi n. sp. (SGHN MA0633, holotype): A, anterior view; B, corresponding line drawing; C, ventral view. Cross-hatching indicates the presence of a concretion. Scale bar: $10 \mathrm{~cm}$.

\section{Vomer}

On the midline of the ventral side of the rostrum of the holotype, a narrow exposure of vomer is visible over a length of $166 \mathrm{~mm}$, from a level $181 \mathrm{~mm}$ posterior to the apex of the rostrum.

\section{Palatine}

The palatine is only partially preserved in the holotype. The anteriormost point of the maxilla-palatine suture is $115 \mathrm{~mm}$ anterior to the level of the antorbital notch.

\section{REMARKS}

The most striking differences between C. leidyi n. sp. and C. planirostris are the general size and the rostrum length. Therefore one has to wonder whether these differences (and the other differences) could be related to ontogeny and/or sexual dimorphism. Measurements of all available specimens of $C$. planirostris (all from the North Sea) show a mean rostrum length of $359 \mathrm{~mm}(\mathrm{n}=27, \mathrm{~min}=$ $297 \mathrm{~mm}, \max =416 \mathrm{~mm}$ ), whereas C. leidyi $\mathrm{n}$. sp. 
(from the Atlantic coast off Galicia) reports 499 $\mathrm{mm}(\mathrm{n}=2$, min $495 \mathrm{~mm}$, max $503 \mathrm{~mm}$ ). It seems obvious that the large North Sea sample cannot be seen as a sexual dimorphic variant of the much larger Galician specimens. Indeed, variation within the North Sea sample (from very slender specimens to more robust specimens, see Lambert [2005: fig. 21]) shows all the aspects of sexual and/or ontogenetic variation within a same species.

\section{Genus Tusciziphius Bianucci, 1997}

TYPe SPECIES. - Tusciziphius crispus Bianucci, 1997, from Tuscany (Italy), early Pliocene, calcareous nannofossil zone MNN14-15 (Bianucci et al. 2001).

OTHER SPECIES INCLUDED. - Tusciziphius atlanticus n. sp.

EMENDED DIAGNOSIs. - Tusciziphius differs from all other ziphiines except Imocetus n. gen. and Globicetus n. gen. in having an extremely ossified trapezoidal vertex in which the anterior part of the nasals contact the premaxillary crests. It differs from Globicetus n. gen. and Imocetus $\mathrm{n}$. gen. in the extreme widening and anterior projection of the right premaxillary crest, and in the lesser posterior constriction of the vertex; it further differs from Globicetus n. gen. in lacking a large spherical medial premaxillary rostral prominence; it further differs from Imocetus in lacking a wide facial depression, a rostral maxillary spur-shaped crest, and in having the premaxillary foramen not located posterior to the level of the antorbital notch. Among the other ziphiine genera it further differs from Ziphius and Izikoziphius in the medial fusion of the premaxillae closing the mesorostral groove; it further differs from the possible ziphiine Caviziphius in the shallower excavation of the premaxillary sac fossae.

\section{Tusciziphius atlanticus n. sp. (Figs 6-9; Table 2)}

HOLOTYPE. - SGHN MA0926, a partial skull including rostrum, facial area, and vertex.

PARATYPE. - NMR 9991-3020, a partial skull including rostrum, facial area, and vertex, originally referred to Tusciziphius crispus (see Post et al. 2008). Morgan River, Beaufort County, South Carolina, USA, between $32^{\circ} 26^{\prime} 50^{\prime \prime} \mathrm{N}, 80^{\circ} 35^{\prime} 57^{\prime \prime} \mathrm{W}$ and $32^{\circ} 27^{\prime} 09^{\prime \prime} \mathrm{N}, 80^{\circ} 28^{\prime} 44^{\prime \prime} \mathrm{W}$. Found reworked on the bottom of a river, it has been proposed to originate from late Miocene-Pliocene layers (Post et al. 2008).
REFERRED SPECIMENS. — SGHN MA0632, a partial skull including rostrum, facial area, and vertex, As Paredes fishing ground, depth of approximately $470 \mathrm{~m}$, off the Galician coast, $44^{\circ} 07^{\prime} \mathrm{N}, 08^{\circ} 07^{\prime} \mathrm{W}$; SGHN MA0644, a partial skull including rostrum, facial area, and vertex, A Selva fishing ground, depth of approximately $500 \mathrm{~m}$, off the Galician coast, $44^{\circ} 10^{\prime} \mathrm{N}, 08^{\circ} 40^{\prime} \mathrm{W}$; SGHN MA0914, a partial skull including rostrum, facial area, and vertex, A Selva fishing ground, depth of approximately $500 \mathrm{~m}$, off the Galician coast, $44^{\circ} 10^{\prime} \mathrm{N}, 08^{\circ} 40^{\prime} \mathrm{W}$; ML1365, a right facial area including right side of the vertex, south of Nazaré Canyon off the Portuguese coast, exact locality unknown, but likely around $39^{\circ} 18^{\prime} \mathrm{N}, 9^{\circ} 47^{\prime} \mathrm{W}$.

ETYMOLOGY. - From the Atlantic Ocean distribution of the species (South Carolina, east coast USA and Iberian Atlantic coast, western Europe).

Type LOCALITY. - Cortada fishing ground, depth of approximately $600 \mathrm{~m}$, off the Galician coast, $43^{\circ} 30^{\prime} \mathrm{N}$, $09^{\circ} 25^{\prime} \mathrm{W}$.

Diagnosis. - Tusciziphius atlanticus n. sp. differs from all other ziphiids in the prominent medial rostral bulge formed by the fused premaxillae, which elevation varies individually and is probably related to sexual dimorphism (this feature cannot be observed in T. crispus, of which the rostrum is unknown; in Aporotus the elevated premaxillae are not fused in a single bulge).

It differs from $T$. crispus in having the right premaxillary sac fossa almost completely (except the posterior portion) filled by compact bone forming a semicircular shelf and in having the excavation for the premaxillary sacs restricted to the posterior portion of both right and left premaxillary sac fossae.

\section{DESCRIPTION}

The holotype, the paratype, and the referred specimens of Tusciziphius atlanticus n. sp., share with T. crispus the similar size, the large and asymmetrical premaxilary sac fossae, and the vertex architecture with the extreme widening and anterior projection of the right premaxillary crest. All the Iberian specimens referred to this species exhibit, when preserved, a moderately elongated rostrum, suggesting that the apparently short rostrum of the paratype may be an artefact due to restoration of the broken apex with plaster (Post et al. 2008).

A prominent medial elevation on the rostrum, formed by the fusion of premaxillae over the mesorostral groove, is visible in three of the four specimens with a preserved rostrum. In the paratype NMR 9991-3020 and in SGHN MA0914, the 
A
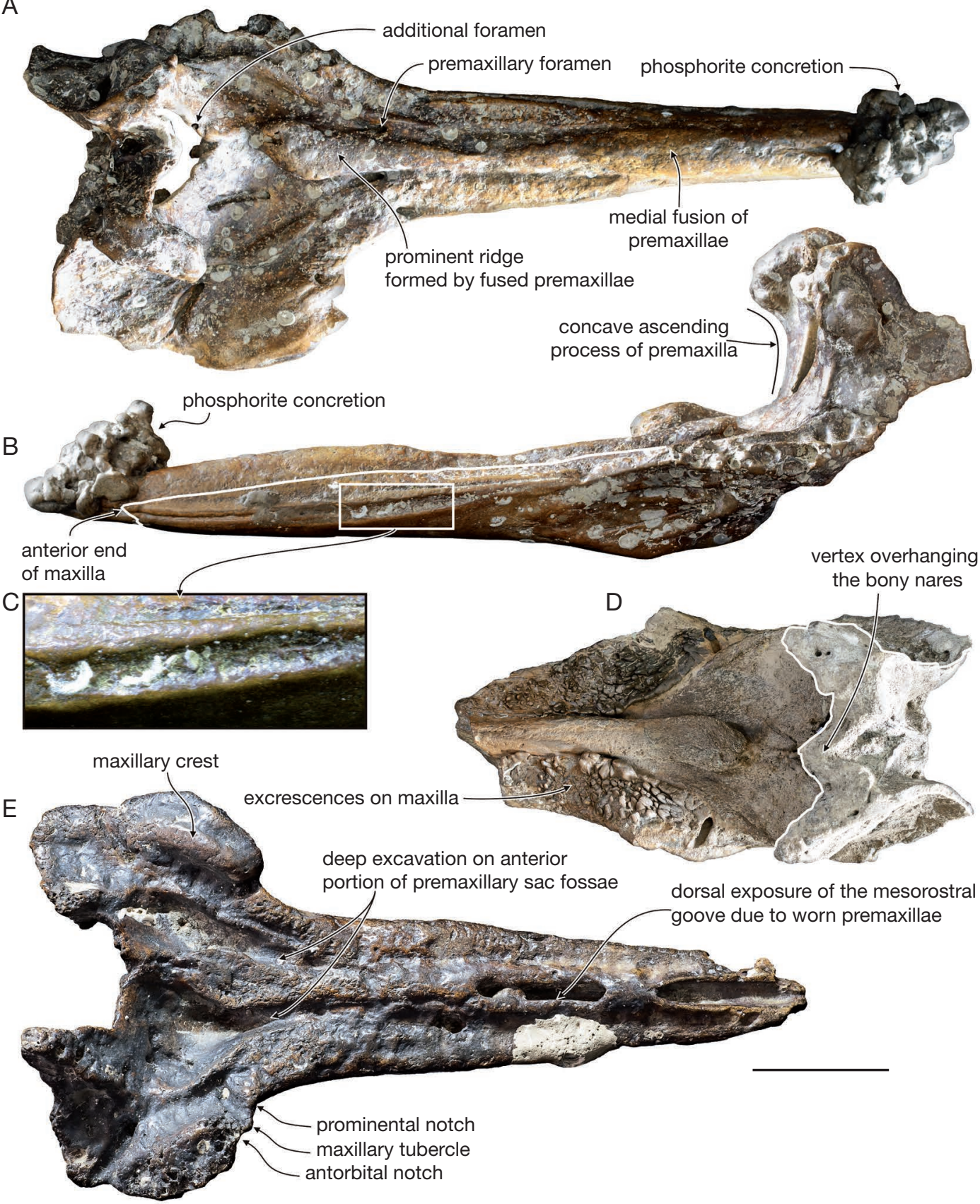

FIG. 5. - A-C, Skull of Choneziphius leidyi n. sp. (SGHN MA0640); A, dorsal view; B, lateral view; C, detail of the rostrum in lateral view showing the vestigial alveolar groove; D, C. leidyi n. sp. (SGHN MA0641), partial skull in dorsal view; E, C. leidyi n. sp. (SGHN ML533), partial skull in dorsal view. Scale bar: $10 \mathrm{~cm}$. 
TABLE 2. - Measurements (in mm) on the skulls of Tusciziphius atlanticus $\mathrm{n}$. sp. from South Carolina (USA) and the Atlantic Ocean floor off the Iberian Peninsula. Abbreviations: e, estimate; +, nearly complete; -, no data.

\begin{tabular}{|c|c|c|c|c|c|}
\hline & $\begin{array}{c}\text { NMR } \\
9991- \\
3020\end{array}$ & $\begin{array}{c}\text { SGHN } \\
\text { MA0632 }\end{array}$ & $\begin{array}{c}\text { SGHN } \\
\text { MA0644 }\end{array}$ & $\begin{array}{c}\text { SGHN } \\
\text { MA0914 }\end{array}$ & $\begin{array}{c}\text { SGHN } \\
\text { MA0926 } \\
\text { (holotype) }\end{array}$ \\
\hline Rostrum length & - & - & - & +425 & +440 \\
\hline Length of premaxillary portion of rostrum & - & _- & _- & +5 & - \\
\hline Distance from apex of rostrum to bony nares & - & - & - & - & +525 \\
\hline Width of rostrum at mid-length & - & - & - & 63 & 64 \\
\hline Height of rostrum at mid-length & - & - & - & 89 & 82 \\
\hline Width of premaxillae at mid-length of rostrum & - & - & - & 26 & 50 \\
\hline Width of rostrum base at antorbital notch & - & - & - & e150 & 230 \\
\hline Width of premaxillae at rostrum base & 86 & _ & _ & 68 & 62 \\
\hline Minimum distance between maxillae near rostrum base & - & - & e51 & - & 62 \\
\hline Distance rostrum base - anterior apex of palatine & e130 & - & - & e170 & 190 \\
\hline Preorbital width of skull & - & - & - & e350 & 320 \\
\hline Postorbital width of skull & +372 & - & - & - & - \\
\hline Width of premaxillary sac fossae & 173 & e171 & 142 & 170 & 150 \\
\hline Width of right premaxillary sac fossa & 108 & 106 & 92 & 105 & 96 \\
\hline Width of left premaxillary sac fossa & 51 & 61 & 46 & 58 & 41 \\
\hline Width of bony nares & 69 & e73 & 53 & 70 & 66 \\
\hline Minimum width of right ascending process of premaxilla & 68 & e60 & 60 & - & - \\
\hline Width of premaxillary crests & e184 & 188 & 155 & - & 180 \\
\hline Width of right premaxillary crest & +101 & e87 & e76 & _ & 101 \\
\hline Width of left premaxillary crest & 51 & 33 & 29 & 48 & 44 \\
\hline Minimum distance between premaxillary crests & e39 & - & e58 & 42 & 61 \\
\hline Maximum width of nasals & - & - & - & 55 & 58 \\
\hline Maximum width of right nasal & e27 & - & - & 29 & 34 \\
\hline Maximum width of left nasal & - & - & - & 27 & 24 \\
\hline Lenght of right nasal & 82 & e67 & 50 & 72 & 88 \\
\hline Length of medial suture of nasals & 68 & - & - & 62 & 71 \\
\hline Minimum posterior distance between maxillae & 84 & e105 & _ & 88 & 76 \\
\hline
\end{tabular}

rostral bulge is present but less developed. This character cannot be observed in T. crispus because the rostrum is not preserved on the holotype and only preserved specimen.

\section{Premaxilla}

Due to the apical erosion of the rostrum, more or less pronounced in all specimens, it is not possible to evaluate the length of the portion of the rostrum formed by the premaxillae alone. In fact, this region is partly preserved $(5 \mathrm{~mm})$ only in SGHN MA0914. In all the specimens, the preserved portion of the rostrum exhibits thick premaxillae with a medial suture, dorsally closing the mesorostral groove. This closure starts from the preserved apical portion of the rostrum in all specimens except in the holotype, where the first $65 \mathrm{~mm}$ of the groove are still dorsally open. The fused premaxillae are massive and protuberant on the rostrum; they form a bulge, with a varying position and height, on which the medial premaxillary suture is completely obliterated.

The development of the medial premaxillary bulge extends from the apex of the rostrum to the level of the antorbital notch in the holotype, SGHN MA0632 and SGHN MA0914, and to the level of the anterior palatine suture in SGHN MA0644. The elevation of the bulge increases anteroposteriorly progressively in the holotype, and more abruptly in SGHN MA0644 and SGHN MA0632. The maximum height of the bulge above the maxilla is $90 \mathrm{~mm}$ in SGHN MA0632, $67 \mathrm{~mm}$ in SGHN MA0644, and $58 \mathrm{~mm}$ in the holotype. In the paratype and in SGHN M0914, only a small dome, respectively 27 and $33 \mathrm{~mm}$ above the maxilla, is present in the posterior part of the rostrum, just anterior to the antorbital notches. 


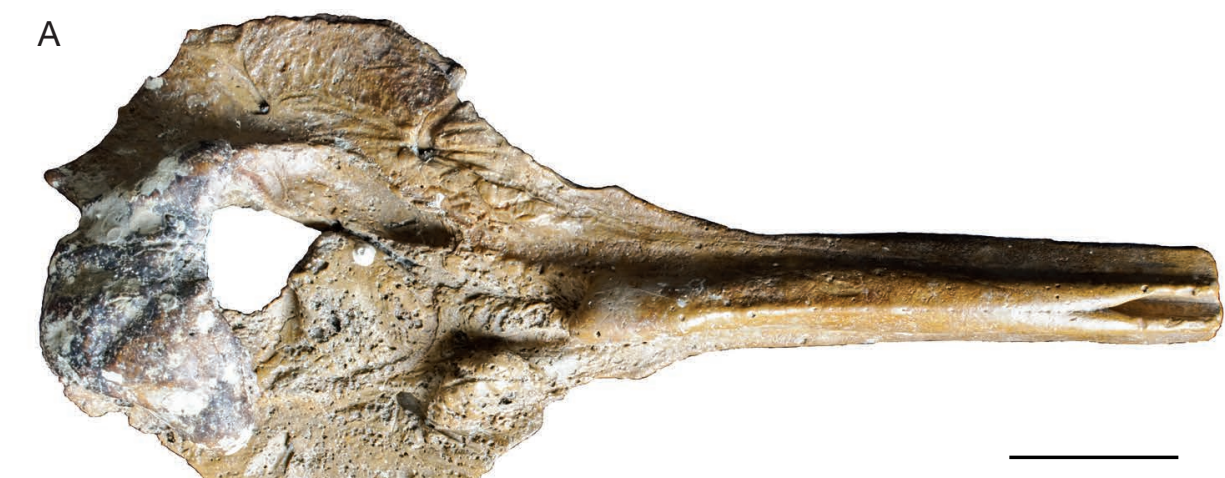

left premaxillary it: if th

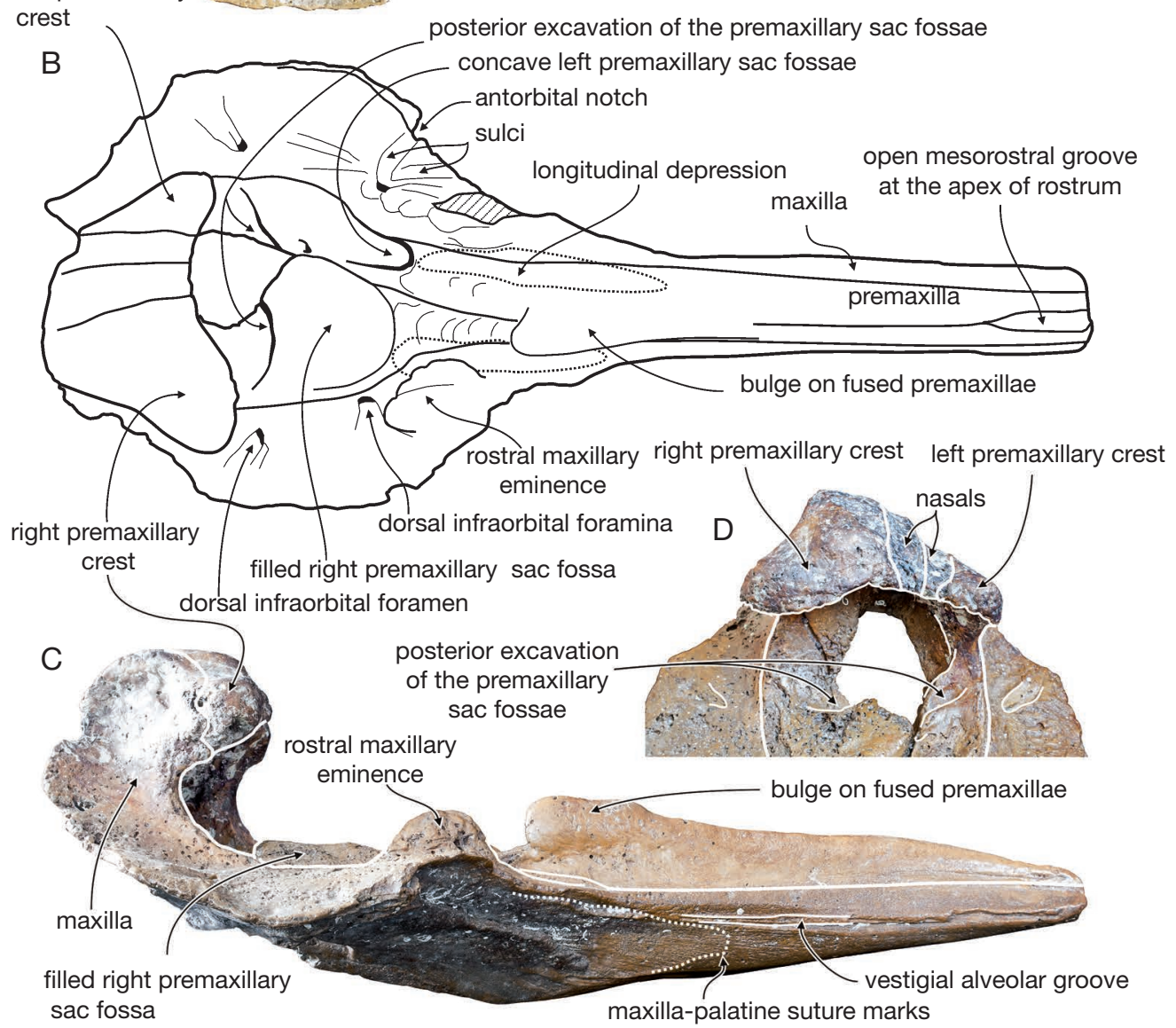

FIG. 6. - Skull of Tusciziphius atlanticus, n. sp. (SGHN MA0926, holotype): A, dorsal view; B, corresponding line drawing; C, lateral view; $\mathbf{D}$, detail of the vertex and premaxillary sac fossae in anterior view. Parallel lines indicate a break surface. Scale bar: $10 \mathrm{~cm}$.

Macroscopic observation of transverse sections along the medial bulge of SGHN MA0632 reveal a high compacity of the bone tissue and the pres- ence of a series of growth layers, a feature already noted in the pachyosteosclerotic rostrum of several other ziphiid taxa (Lambert 2005; Buffrénil \& 

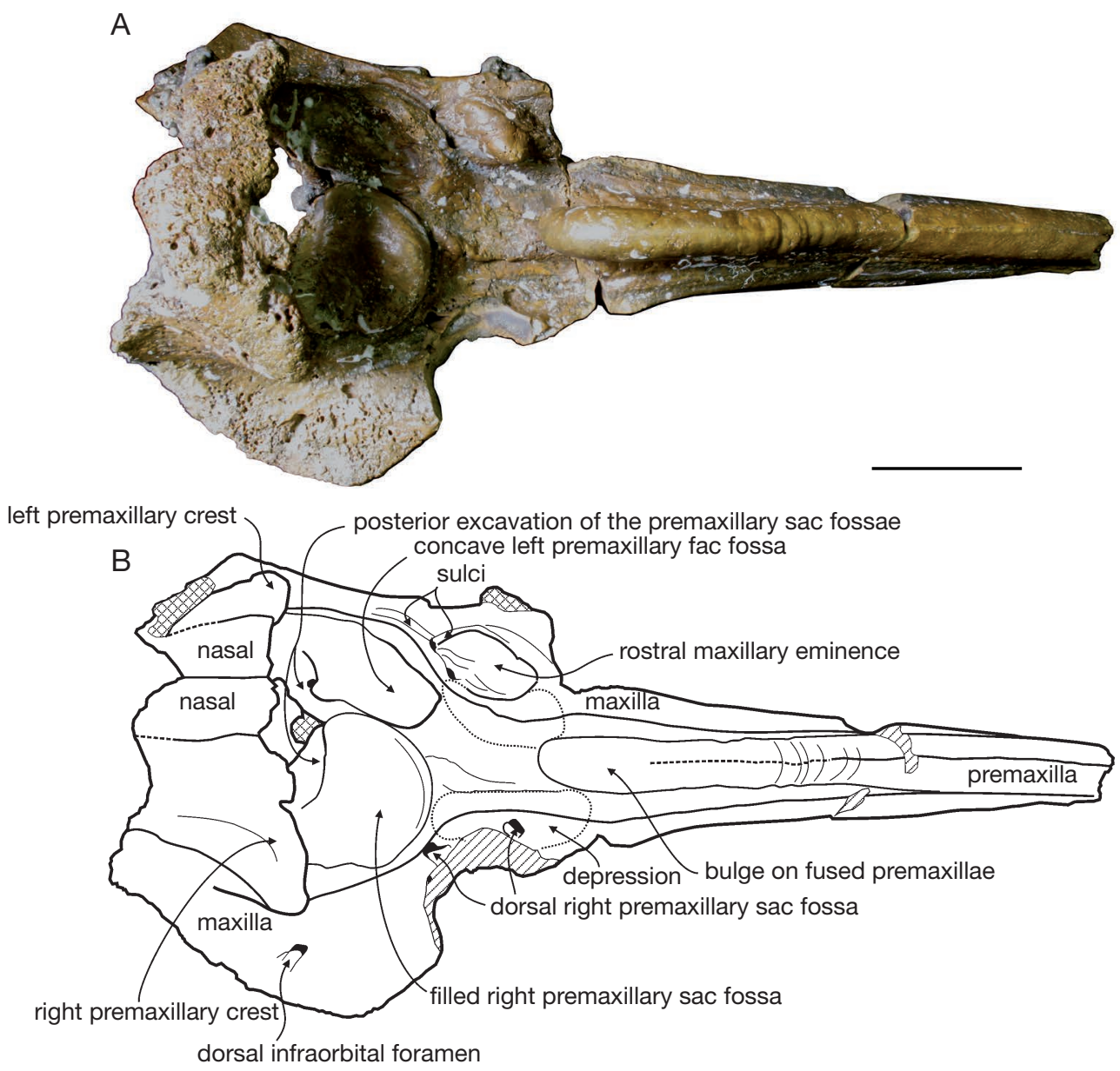

FIG. 7. - Skull of Tusciziphius atlanticus, n. sp. (SGHN MA0632): A, dorsal view; B, corresponding line drawing. Cross-hatching indicates the presence of a concretion; tight parallel lines indicate a break surface. Scale bar: $10 \mathrm{~cm}$.

Lambert 2011; Lambert et al. 2011). Posterior to the premaxillary bulge, there is a low medial shelf laterally delimited by two shallow depressions and posteriorly margined by the premaxillae sac fossae. The premaxillary sac fossae are strongly asymmetric in all the specimens of T. atlanticus $\mathrm{n}$. sp. (ratio between the left and right width ranging from 0.43 to 0.57 ) and in T. crispus (0.44). However, in all the specimens of T. atlanticus $\mathrm{n}$. sp. the anterior part of the right premaxillary sac fossa is completely filled by compact bone, forming a thick semicircular shelf. The filling is absent in the left premaxillary fossa, which is deeply concave in all specimens. Instead, in T. cripsus both premaxillary sac fossae are excavated. The deep concavity of the premaxillary sac fossae is likely a derived condition shared with Caviziphius, Choneziphius, Globicetus n. gen., and Imocetus n. gen., whereas the semicircular shelf that partially fills the right premaxillary fossa in T. atlanticus n. sp. may be homologous with the rectangular premaxillary shelf of Globicetus $n$. gen. (see below). Due to the presence of the anterior shelf, the posterior portion of the right premaxillary sac fossa displays an abrupt anterior slope. Interestingly, a similar step is present at the same level in the fully concave left premaxillary sac 

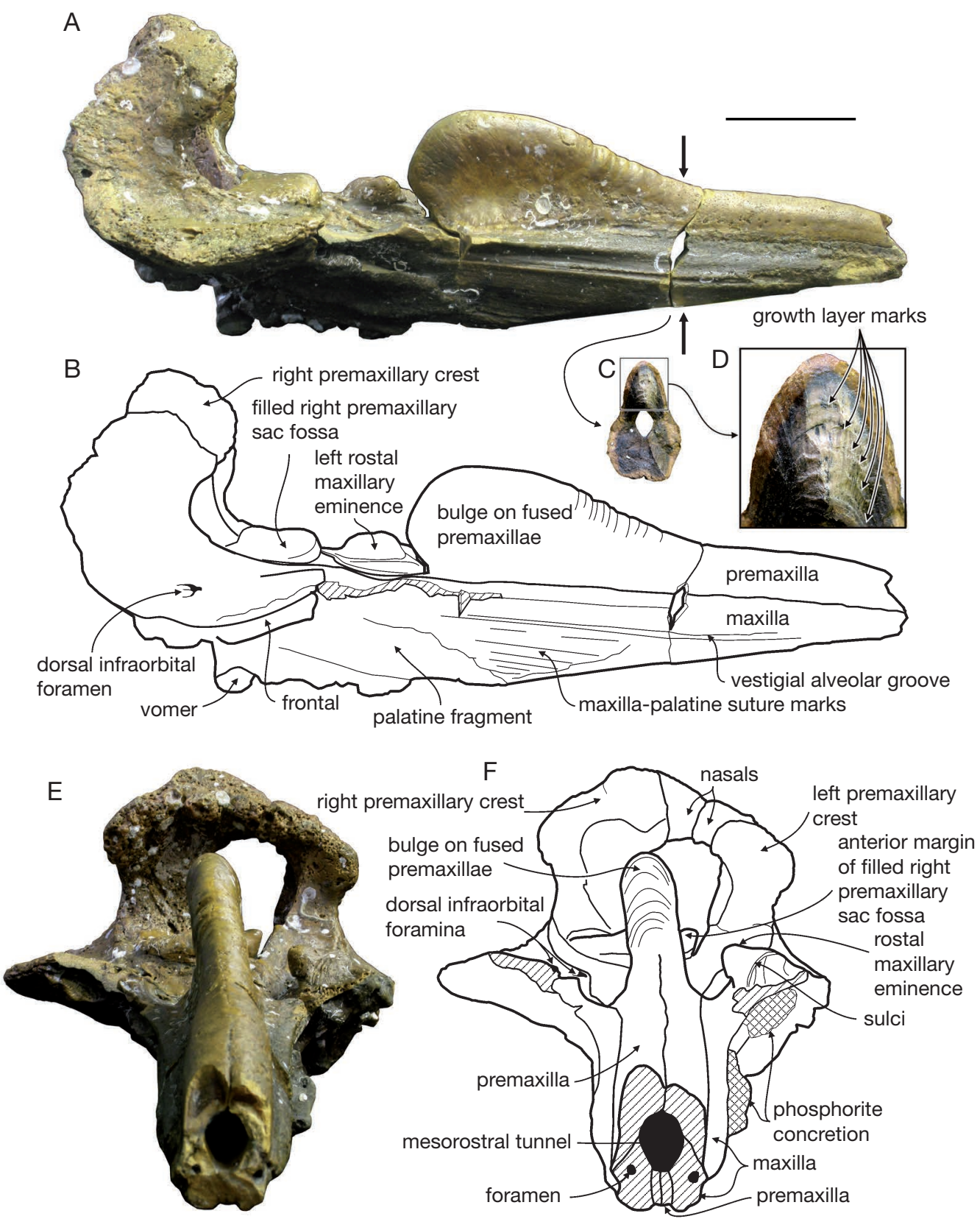

FIG. 8. - Skull of Tusciziphius atlanticus n. sp. (SGHN MA0632): A, lateral view; B, corresponding line drawing (the arrows indicate the level of the transverse section); $\mathbf{C}$, transverse section through the rostrum; $\mathbf{D}$, detail of $\mathbf{C}$ showing the growth layers; $\mathbf{E}$, anterior view; $\mathbf{F}$, corresponding line drawing. Cross-hatching indicates the presence of a concretion; tight parallel lines indicate a break surface. Scale bar: $10 \mathrm{~cm}$.

fossa. No premaxillary foramen is observed at the anterior end of the premaxillary sac fossae. Only one foramen is visible near the medial margin of the left fossa in the holotype, in the paratype, and SGHN MA0914, absent in SGHN MA0632 and SGHN MA0644. Similar to T. crispus, the ascend- 
ing process of the premaxilla of T. atlanticus n. sp. exhibits a strong transverse constriction. Its posterior portion is anteriorly curved, overhanging the premaxillary sac fossa and bony nares. The right premaxillary crest of T. atlanticus $n$. sp. shows the extreme transverse widening typical for Tusciziphius. Moreover, as in T. crispus, the right premaxillary crest is more anteriorly projected than the left. For this character, Tusciziphius clearly differs from the closely related Globicetus n. gen., in which both crests have approximately the same anterior extent. This difference may be related to the different direction of the right premaxillary crest (anterolateral in Tusciziphius and more transversal in Globicetus n. gen.). Finally, as in Globicetus n. gen., Imocetus n. gen., and especially Caviziphius, the right premaxillary crest is considerably larger and especially higher than the left, a feature best seen in anterior view. Moreover, due to the fact that the right premaxillary crest is considerably higher than the left one, the dorsal surface of the right nasal is more medially inclined than that of the left nasal.

\section{Maxilla}

The distal half part of the rostrum is narrow and strongly transversally compressed. Consequently the dorsal surface of the maxilla is nearly vertical and almost invisible in dorsal view. In the proximal half portion, the lateral inclination of the maxilla decreases progressively, with a wider portion visible in dorsal view.

At the rostrum base, just medial to the right antorbital notch, the holotype and SGHN MA0644 develop a high and voluminous rostral maxillary eminence, slightly medially curved. SGHN MA0632 lacks a portion of the right maxilla that probably included, judging from the shape and the position of the broken surface, a similar eminence. On the left side of the holotype, SGHN MA0644, and SGHN MA0632, the maxilla exhibits a similar but lower rostral maxillary eminence. In the paratype and SGHN MA0914, no prominent rostral maxillary eminence is present, only some irregular excrescences. On both sides of skulls bearing rostral maxillary eminences, a shallow longitudinal depression is margined laterally by the eminence, slightly overhanging the depression, and medially by the low medial premaxillary shelf. One to three dorsal infraobital foramina pierce the maxilla near the rostrum base, medial and/or posterior to the rostral maxillary eminence (when the eminence is present). From these foramina, several sulci run anteriorly and posteriorly. The vestigial alveolar groove is a narrow sulcus, with no visible alveoli.

\section{Nasal}

The shape of the nasals, as the general architecture of the vertex, is rather stable in T. atlanticus n. sp. and $T$. crispus. The sutures of the nasals are generally hard to detect due to the extreme ossification and fusion of the vertex bones. The nasals are anteroposteriorly elongated, with lateral margins parallel or faintly convergent (but not as much as in Globicetus n. gen.). As in Globicetus n. gen. and Imocetus $\mathrm{n}$. gen., the lateral margin of the nasal is in contact with the premaxillary crest for all its extent and the dorsal surface of the joined nasals forms a shallow depression between the premaxillary crests.

\section{Frontal}

The frontals are visible on the vertex of several specimens. They are wider than in Globicetus n. gen. and Imocetus n. gen., related to the lesser transverse constriction of the posterior part of the vertex.

\section{Vomer}

The vomer is not visible dorsally due to the complete closure of the mesorostral groove. It is visible only ventrally between the premaxillae and the maxillae along the mid-line of the rostrum, and anterior to the choanae due to the non-preservation of the palatine in that area.

\section{Palatine}

The palatine is partially preserved only in SGHN MA0914. The maxilla-palatine suture extends about $150 \mathrm{~mm}$ anterior to the antorbital notch, the level of the abrupt widening of the rostrum.

\section{REMARKS}

The previous assignation of the South Carolina paratype of Tusciziphius atlanticus n. sp. to the Italian species T. crispus was made at a time when only one skull was known (Post et al. 2008), preventing 


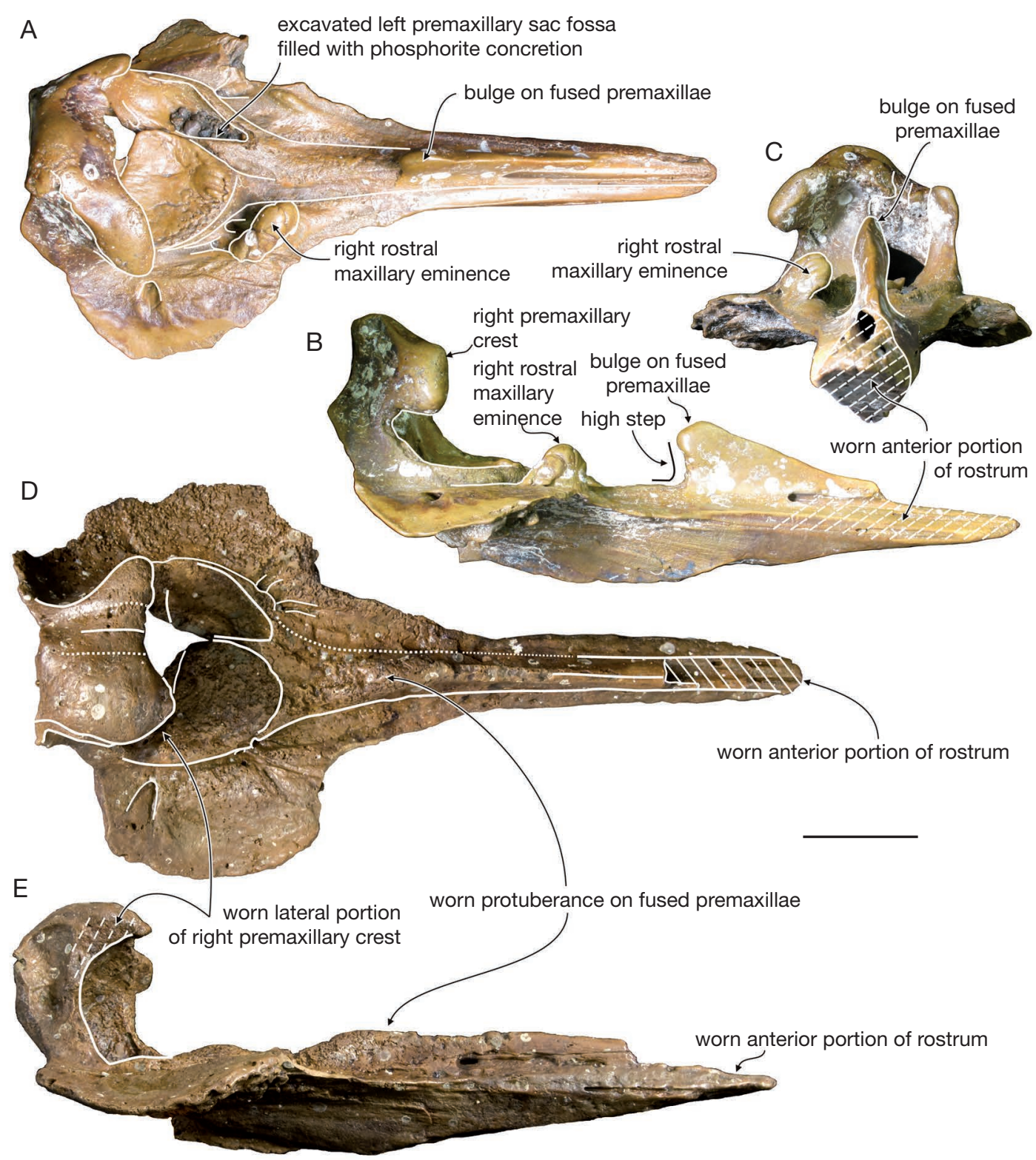

FIG. 9. - A-C, skull of Tusciziphius atlanticus, n. sp. (SGHN MA0644); A, dorsal view; B, lateral view; C, anterior view. D, E, skull of T. atlanticus, n. sp. (SGHN MA0914); D, dorsal view; E, lateral view. Parallel lines indicate superficial wear. Scale bar: $10 \mathrm{~cm}$.

any evaluation of the intraspecific or interspecific character for the variation at the level of the premaxillary sac fossae. The observation of the same filling of the right premaxillary sac fossa in all the examined skulls from the Atlantic Ocean floor off the Iberian Peninsula suggests that this character is valid for the definition of a new species, grouping the South Carolina specimen with the Iberian specimens. Additional specimens of T. crispus from Italy could confirm this interpretation in the future. 


\section{Genus Globicetus n. gen.}

TyPe AND ONLY SPECIES. - Globicetus hiberus n. gen., n. sp., by present designation.

ETYMOLOGY. - From Latin "globus", for the large spherical medial premaxillary prominence on the rostrum, and from Latin "cetus", whale. Gender masculine.

DiagnOSIs. - Same as for the species.

Globicetus hiberus n. sp.

(Figs 10-13; Table 3)

HoLOTYPE. - ML 1361, partial skull including rostrum, facial area and vertex.

REFERRED SPECIMENS. - MHNUSC 3958, partial skull including facial area and vertex, 20 miles from Touriñán Cape, off the Galician coast, depth of $1500 \mathrm{~m}, 42^{\circ} 50^{\prime} \mathrm{N}$, $9^{\circ} 40^{\prime} \mathrm{W}$; IEO DR26 026, partial skull including rostrum and anterior portion of facial area, off the Galician coast, depth of approximately $1500 \mathrm{~m}, 42^{\circ} 27^{\prime} \mathrm{N}, 11^{\circ} 59^{\prime} \mathrm{W}$.

Eтyмology. - From Latin "hiberus", Iberian, for the geographical origin of the holotype and referred specimens.

Type Locality. - South of Nazaré Canyon off the Portuguese coast, exact locality unknown, but likely around $39^{\circ} 18^{\prime} \mathrm{N}, 9^{\circ} 47^{\prime} \mathrm{W}$.

Diagnosis. - Globicetus hiberus n. gen., n. sp. differs from all other ziphiids in the large spherical medial rostral prominence formed by the fused premaxillae, in the large prominence of the right premaxilla anterior to the right premaxillary sac fossa, and in the barely marked antorbital notch, related to the important widening of the rostrum base.

Among the other ziphiine genera it further differs from Ziphius and Izikoziphius in the medial fusion of the premaxillae closing the mesorostral groove; it shares with Imocetus $\mathrm{n}$. gen. and Tusciziphius the anterior part of the nasal contacting the premaxillary crest and the extreme ossification and fusion of the vertex elements, but it differs from Imocetus $\mathrm{n}$. gen. in lacking a wide facial depression, rostral maxillary spur-shaped crest, and in having the premaxillary foramina not located posterior to the level of the antorbital notch; it differs from Tusciziphius in the less transversally expanded vertex (lower width between the premaxillary crests, and lower distance between maxillae posterior to the vertex), and in the posterolateral direction of the right premaxillary crest. It further differs from the possible ziphiine Caviziphius in shallower excavation of the premaxillary sac fossae.

\section{DESCRIPTION}

The skull is slightly smaller than in the largest specimens of Imocetus piscatus n. gen., n. sp. (see below), with a postorbital width estimated at $372 \mathrm{~mm}$ in the holotype. The rostrum is elongated and its base is wide. The posterior half of the rostrum is characterized by the extreme thickening of the premaxillae, forming a large spherical prominence followed towards the right premaxillary sac fossa by a high shelf (see below). The facial area is short with the low and wide vertex overhanging it, hiding the bony nares and most of the premaxillary sac fossae in dorsal view.

\section{Premaxilla}

On the roughly complete rostrum of the holotype the premaxilla is slightly longer apically $(20 \mathrm{~mm})$ than the maxilla. On the anterior half of the massive and subcylindrical rostrum, the mesorostral groove is dorsally closed by the thick premaxillae, displaying a medial sutural contact. In dorsal view, the posterior half of the rostrum is partly covered by a large, roughly spherical, element made by the joined premaxillae. Preserved on the holotype and IEO DR26 026 , this unusual prominence has a maximum width of $150 \mathrm{~mm}$ and $141 \mathrm{~mm}$ respectively in these two specimens and a maximum height above the maxilla of $135 \mathrm{~mm}$ and $92 \mathrm{~mm}$. It is slightly asymmetrical, higher on the right side of the holotype and longer on the right side of IEO DR26 026. It is made, at least superficially, by compact bone, covered with narrow and shallow anastomosed sulci likely related to vascularization. On the holotype, the anterior and anterolateral margins of the spheroid do not contact the underlying premaxilla and maxilla, leaving an open space of about $10 \mathrm{~mm}$, whereas in IEO DR26 026 a high medial pad of bone joins the spheroid to the dorsal surface of the rostrum. Posteriorly, the spheroid is followed by a thick shelf predominantly constituted by the right premaxilla, whose surface is similarly compact and covered with sulci. Rectangular in dorsal view in the holotype, this shelf is distinctly narrower distally in IEO DR26 026 and in the anteriorly incomplete skull MHNUSC 3958. In lateral view the dorsal margin of the shelf of the latter raises forwards similarly to the more complete specimens, suggesting the presence of a similar large 


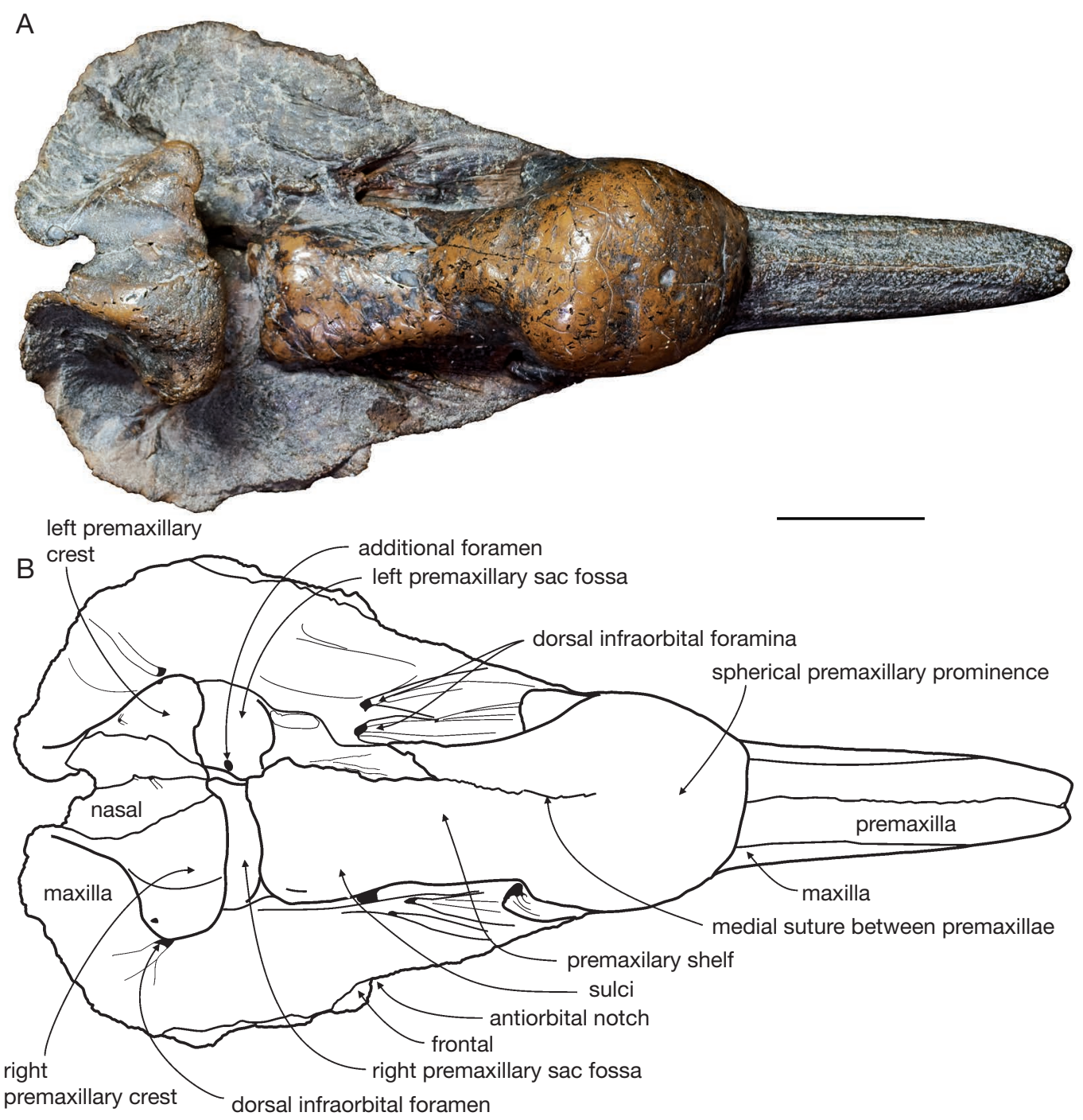

FIG. 10. - Skull of Globicetus hiberus n. gen., n. sp. (ML 1361, holotype): A, dorsal view; B, corresponding line drawing. Scale bar: $10 \mathrm{~cm}$.

spheroid in MHNUSC 3958. The abrupt posterior margin of the shelf corresponds to the anterior limit of the right premaxillary sac fossa, which is considerably wider than the left fossa. Only a narrow and much lower longitudinal crest is located anterior to the left premaxillary sac fossa of the holotype and MHNUSC 3958. Both fossae are short anteriorly, more than in Tusciziphius, nearly completely dorsally overhung by the vertex. The presence of the massive shelf in Globicetus n. gen., associated with shorter premaxillary sac fossae, might be interpreted as an overgrowth of the thickened anterior portion of the right premaxillary sac fossa observed in T. atlanticus n. sp. The surface of the premaxillary sac fossae is strongly concave and no premaxillary foramen could be detected on the bottom of any of the fossae. Only one foramen is observed on the medial margin of the left fossa of the three specimens, similar to the condition in Choneziphius leidyi n. sp., Imocetus n. gen., and T. atlanticus n. sp. 
TABLE 3. - Measurements (in mm) on the skulls of Globicetus hiberus n. gen., n. sp. from the Atlantic Ocean floor off the lberian Peninsula. Abbreviations: e, estimate; +, nearly complete; -, no data.

\begin{tabular}{lcrc}
\hline & $\begin{array}{c}\text { ML 1361 } \\
\text { (holotype) }\end{array}$ & MLI 3958 & IEO DR 26026 \\
\hline Rostrum length & 530 & - & 552 \\
Length of premaxillary portion of rostrum & 20 & - & - \\
Distance from apex of rostrum to bony nares & 665 & - & e650 \\
Width of rostrum at mid-length & 99 & - & 93 \\
Height of rostrum at mid-length & 98 & - & 99 \\
Width of rostrum base at antorbital notch & 265 & e285 & e233 \\
Width of premaxillae at rostrum base & 104 & - & - \\
Minimum distance between maxillae near rostrum base & - & 80 & - \\
Distance rostrum base - anterior apex of palatine & 227 & - & 315 \\
Preorbital width of skull & - & +335 & - \\
Postorbital width of skull & 372 & - & +305 \\
Longitudinal distance right premaxillary foramen - rostrum base & 78 & - & 72 \\
Width of premaxillary sac fossae & 170 & +165 & - \\
Width of right premaxillary sac fossa & 100.5 & 83 & - \\
Width of left premaxillary sac fossa & 62.5 & -74 & - \\
Width of bony nares & 79 & 82 & - \\
Minimum width of right ascending process of the premaxilla & 44 & 42 & - \\
Minimum width of left ascending process of the premaxilla & 23 & -17 & - \\
Width of premaxillary crests & 185 & 170 & - \\
Width of right premaxillary crest & 106 & 84 & - \\
Width of left premaxillary crest & 70 & 51 & - \\
Maximum width of nasals & 69.5 & 68 & - \\
Maximum width of right nasal & - & 47 & - \\
Maximum width of left nasal & - & 28 & - \\
Length of medial suture of nasals & 68 & $e 62$ & - \\
\hline
\end{tabular}

The ascending process of each premaxilla is strongly constricted and short. On the low vertex, the overhanging right premaxillary crest is much wider than the left, reaching laterally a level beyond the lateral margin of the corresponding premaxillary sac fossa. The top of the vertex is made by the right premaxilla, much higher than the left. The anterior margin of the right premaxillary crests is posterolaterally directed, whereas the anterior margin of the left premaxillary crest is roughly anterolaterally directed. In Tusciziphius both crests are usually anterolaterally directed.

\section{Maxilla}

Apically invisible in dorsal view, the maxilla only slightly widens along the distal half of the rostrum, with a somewhat medially convex maxilla-premaxilla suture. From the level of the large spheroid it sends a thin lateral plate whose lateral margin reaches the preorbital process in a nearly rectilinear line, forming a wide rostrum base. Differing from T. atlanticus n. sp. and Imocetus n. gen., the antorbital notch is therefore barely individualized; a wide subhorizontal surface margins the premaxillary shelf on both sides of the rostrum base. This surface is pierced by several dorsal infraorbital foramina, three on the right side and two on the left side of the holotype, one less on the right side of MHNUSC 3958, and one less on each side of IEO DR26 026. From these foramina, several sulci are sent anteriorly and anterolaterally. A large longitudinal sulcus passes between the spheroid of the premaxillae and the maxilla, exiting on the anterior margin of the spheroid.

On the supraorbital area, the maxilla is thin, lacking any maxillary crest contrary to part of the specimens of T. atlanticus n. sp. and Imocetus n. gen. Posterior to the nasals on the vertex, left and right maxillae are close to each other, more than in Tusciziphius, with a minimal distance between the maxillae lower than the width of the nasals. At this level the medial margin of the right maxilla is 

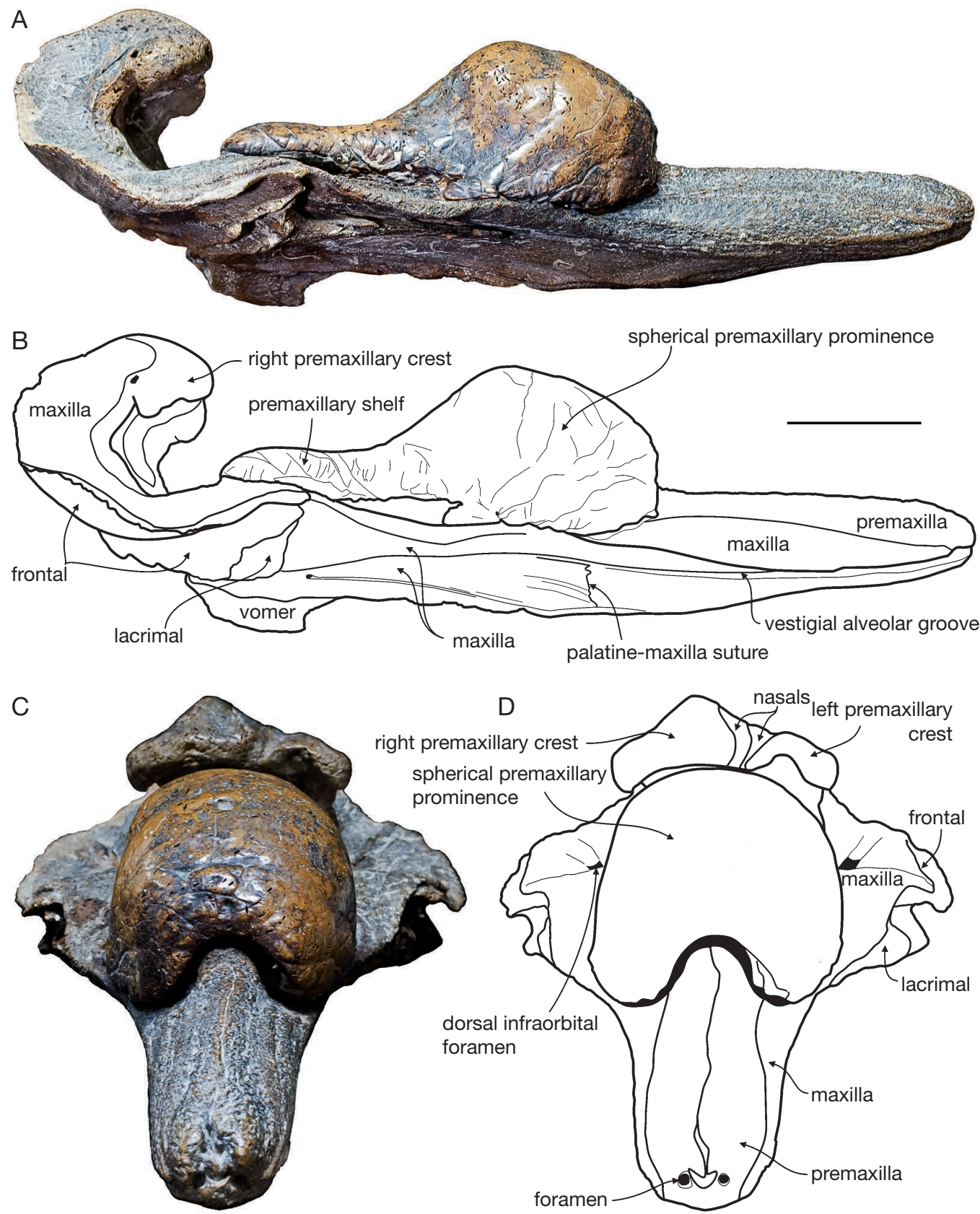

FIG. 11. - Skull of Globicetus hiberus n. gen., n. sp. (ML 1361, holotype): A, lateral view; B, corresponding line drawing; C, anterodorsal view; D, corresponding line drawing. Scale bar: $10 \mathrm{~cm}$.

more erected than the margin of the left maxilla; the latter is the continuation of the depressed dorsal surface of the nasals.
On the ventrolateral surface of the rostrum, the remnant of alveolar groove does not contain individualized alveoli. 


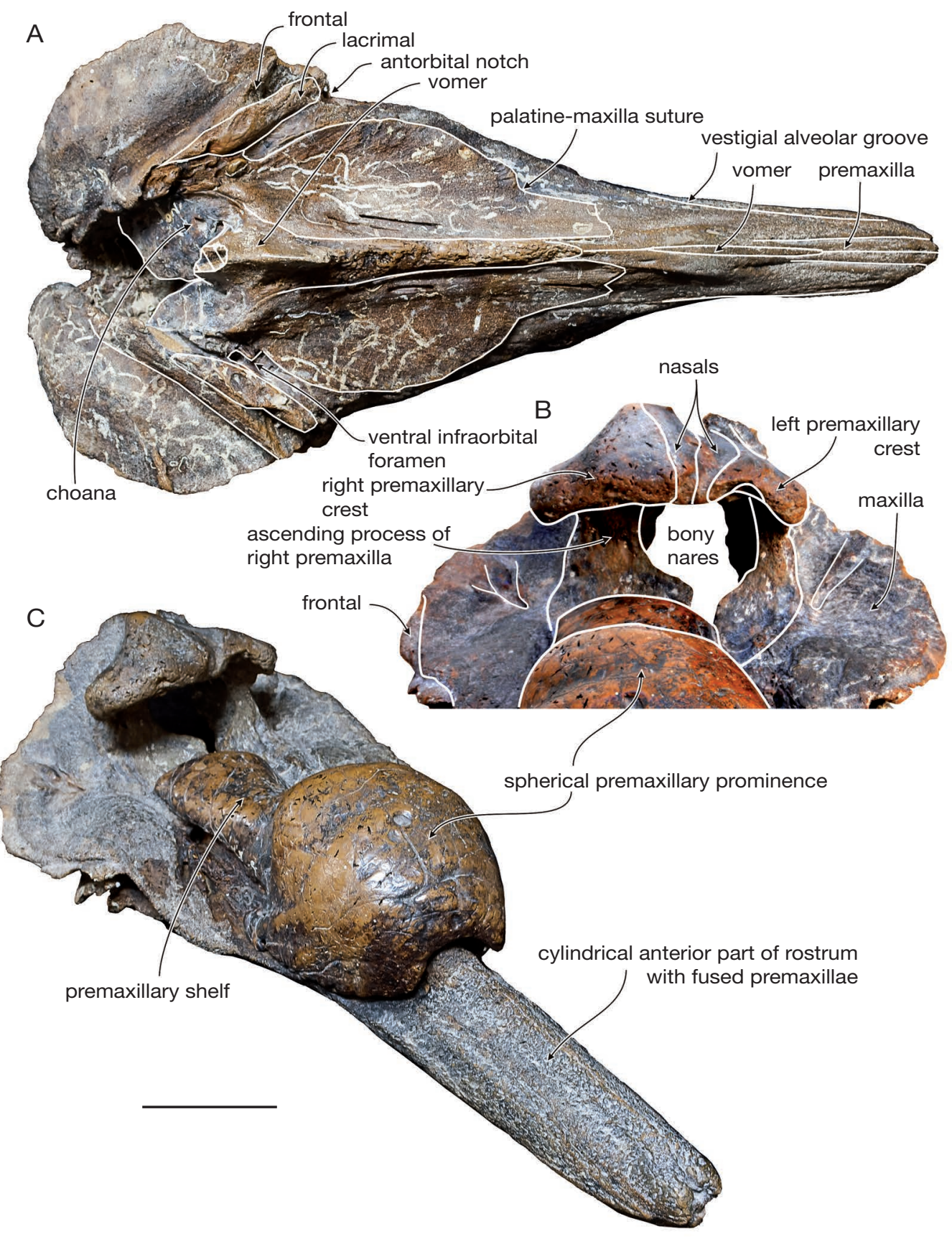

FIG. 12. - Skull of Globicetus hiberus n. gen., n. sp. (ML 1361, holotype): A, ventral view; B, detail of the facial area in anterior view; C, anterolateral view; D, corresponding line drawing. Scale bar: $10 \mathrm{~cm}$. 


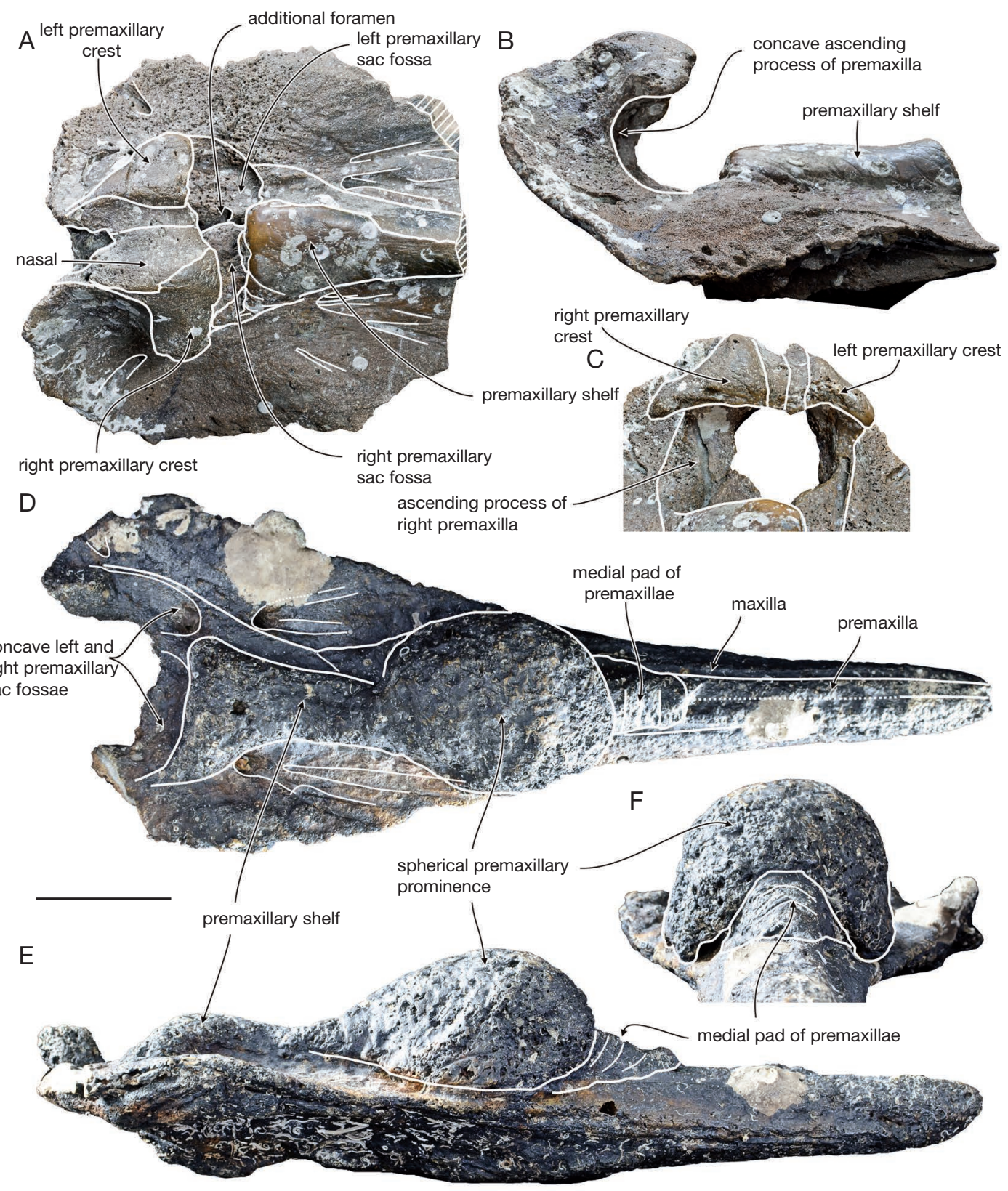

FIG. 13. - A-C, partial skull of Globicetus hiberus n. gen., n. sp. (MHNUSC 3958): A, dorsal view; B, lateral view; C, detail of the vertex and premaxillary sac fossae in anterior view; D-F partial skull of G. hiberus n. gen., n. sp. (IEO DR26 026); D, dorsal view; E, lateral view; $\mathbf{F}$, detail of the spherical premaxillary prominence in anterior view. Parallel lines indicate a break surface. Scale bar: $10 \mathrm{~cm}$. 


\section{Nasal}

Excluded from the premaxillary crest, the nasal is considerably narrower anteriorly than posteriorly. The dorsal surface of the joined nasals forms a depression between the premaxillary crests, as in Imocetus n. gen. and Tusciziphius. The anterior tip of the nasals does not reach a level anterior to the premaxillary crests, differing from Izikoziphius and Ziphius. The medial suture is distinctly shifted to the left side compared to the sagittal plane of the skull.

\section{Frontal}

Only parts of the frontal are preserved on the heavily worn supraorbital area. Frontals are lost on the vertex; they apparently originally formed an anteromedial projection between nasals.

\section{Vomer}

Hidden dorsally by the development of the premaxillae, the vomer is only visible ventrally between the premaxillae and between the maxillae. At the rostrum base, its ventral exposure between the maxillae of the holotype is likely due to partial wear of the latter and loss of the palatines.

\section{Palatine}

Most parts of the palatine are likely lost in the three specimens. A large depression with a distinct outline marks the original anterior extent of the palatine on the rostrum, far anterior from the antorbital notch. The palatine was longer in IEO DR26 026, reaching a level $315 \mathrm{~mm}$ anterior to the notch.

\section{Lacrimal}

The lacrimal is only partly preserved ventral to the maxilla on the preorbital process of the holotype. Its ventral exposure appears rather narrow but its original extension cannot be estimated due to the bad preservation of the ventral surface of the skull.

\section{REMARKS}

A series of arguments support the interpretation of the conspicuous spheroid at the rostrum base of Globicetus hiberus n. gen., n. sp. as a non-pathological element. First, it is present with a very similar outer shape in two of the described specimens. it has also been observed by us in additional undescribed skulls kept in private collections, and its presence is very likely in the third described specimen. In addition, from a morphological point of view, it is nearly symmetrical, with smooth surfaces contrasting with different kinds of pathological bone growths. Furthermore, canals for vascularization/innervation at the base of the spheroid are not interrupted. Finally no fracture or pathological bone tissue has been detected ventral to the spheroid in any of the described specimens.

From a systematic point of view, a dorsomedial sutural contact between the premaxillae is observed on the rostrum of part of the ziphiines (Choneziphius, Imocetus n. gen., and Tusciziphius) and members of the "Messapicetus clade". The general morphology of the low and wide, trapezoidal, extremely ossified, and strongly asymmetric vertex, overhanging the bony nares and the premaxillary sac fossae, closely resembles Tusciziphius and, in a lesser extent, Imocetus $\mathrm{n}$. gen. A superficially similar morphology is also observed in the hyperoodontine Hyperoodon, but in this case the nasal is deeply thrusted in the premaxillary crest and the left premaxillary crest is distinctly directed posterolaterally. The development of a high medial prominence of the joined premaxillae on the rostrum is similarly observed in some specimens of Tusciziphius atlanticus $\mathrm{n}$. sp. and in a fragmentary skull referred here to aff. Caviziphius sp. (see below). In none of these specimens the prominence displays a spherical volume shape. Additional differences with Tusciziphius are: large prominence of the right premaxilla anterior to the right premaxillary sac fossa; barely marked antorbital notch, related to the important widening of the rostrum base; less transversally expanded vertex (lower width between the premaxillary crests and lower distance between the maxillae posterior to the vertex); and posterolateral direction of the right premaxillary crest.

\section{Genus Imocetus n. gen.}

TyPE AND ONLY SPECIES. - Imocetus piscatus n. sp., by present designation.

ETymology. - From Latin "imum", bottom, because it was trawled on the sea floor, and from Latin "cetus", whale. Gender masculine.

DiaGNOSIs. - Same as for the species. 
TABLE 4. - Measurements (in mm) on the skulls of Imocetus piscatus n. gen., n. sp. from the Atlantic Ocean floor off the Iberian Peninsula. Abbreviations: e, estimate; +, nearly complete; - , no data.

\begin{tabular}{lrrr}
\hline & $\begin{array}{c}\text { ML 1358 } \\
\text { (holotype) }\end{array}$ & ML 1359 & ML 1360 \\
\hline Rostrum length as preserved & 495 & 382 & 326 \\
Distance from apex of rostrum to bony nares & - & +392 & - \\
Width of rostrum 100 mm from apex & 68 & +58 & - \\
Width of premaxillae 100 mm from apex & - & - \\
Width of rostrum 200 mm from apex & 99 & 101 & - \\
Width of premaxillae $200 \mathrm{~mm}$ from apex & - & 51 & - \\
Width of rostrum 300 mm from apex & 149 & 145 & - \\
Width of premaxillae 300 mm from apex & - & 52 & - \\
Width of rostrum 400 mm from apex & 212 & - & - \\
Width of rostrum base at antorbital notch & 256 & 199 & 165 \\
Width of premaxillae at antorbital notch & - & 63 & - \\
Distance rostrum base - apex of palatine-pterygoid suture & 158 & 85 & 110 \\
Maximum distance between lateral margins of rostral maxillary crests & 198 & 205 & 162 \\
Minimum distance between maxillary crests (on neurocranium) & 186 & - & - \\
Distance rostrum base - anterior end of premaxillary sac fossa & 211 & 367 & - \\
Width of right premaxillary sac fossa & $e 64$ & - & - \\
Width of left premaxillary sac fossa & -60 & - & - \\
Width of bony nares & 76 & - & - \\
Minimum width of right ascending process of the premaxilla & 29 & - & - \\
Width of premaxillary crests & +139 & - & - \\
Maximum width of nasals & 70 & - & - \\
Minimum posterior distance between maxillae & 51 & - & - \\
\hline
\end{tabular}

Imocetus piscatus n. sp. (Figs 14-17; Table 4)

HolOTYPE. - ML 1358, partial skull including rostrum, facial area and vertex.

REFERRED SPECIMENS. - ML 1359, partial skull including rostrum and anterior portion of facial area and ML 1360, partial skull including rostrum and anterior portion of facial area, south of Nazaré Canyon off the Portuguese coast, exact locality unknown, but likely around $39^{\circ} 18^{\prime} \mathrm{N}, 9^{\circ} 47^{\prime} \mathrm{W}$.

ETYMology. - From Latin "piscatus", fished, because the holotype and the referred specimens were collected at sea by fishermen.

Type Locality. - South of Nazaré Canyon off the Portuguese coast, exact locality unknown, but likely around $39^{\circ} 18^{\prime} \mathrm{N}, 9^{\circ} 47^{\prime} \mathrm{W}$.

DiAgNOSIs. - Imocetus piscatus n. gen., n. sp. differs from all other ziphiids in a wide and anteroposteriorly elongated facial depression laterally margined by acute longitudinal maxillary crests, a rostral maxillary crest forming a posterodorsally directed spur, and premaxillary foramen located very posterior to the level of the antorbital notch. Among other ziphiines it further differs from Izikoziphius and Ziphius in the medial fu- sion of the premaxillae closing the mesorostral groove; it shares with Globicetus n. gen. and Tusciziphius the anterior part of the nasal contacting the premaxillary crest, and the extreme ossification and fusion of the vertex elements, but it differs from Globicetus n. gen. in lacking a large spherical medial premaxillary rostral prominence and in the presence of a distinct antorbital notch. It differs from Tusciziphius in the less transversally expanded vertex (lower width between the premaxillary crests and lower distance between the maxillae posterior to the vertex), and in the posterolateral direction of the right premaxillary crest. It further differs from the possible ziphiine Caviziphius in the less excavated premaxillary sac fossae.

\section{DESCRIPTION}

The skull is large for a fossil ziphiid; based on the width of the rostrum it is close to the size of the modern Mesoplodon layardii. At the apex, the tapered rostrum is cylindrical, whereas it is wider at its base. The anteroposterior length of the rostrum is less than half the estimated condylobasal length. The rostrum is proportionally longer in the holotype, in which the antorbital notch is more posteriorly located than in ML 1359 and ML 1360. The ros- 


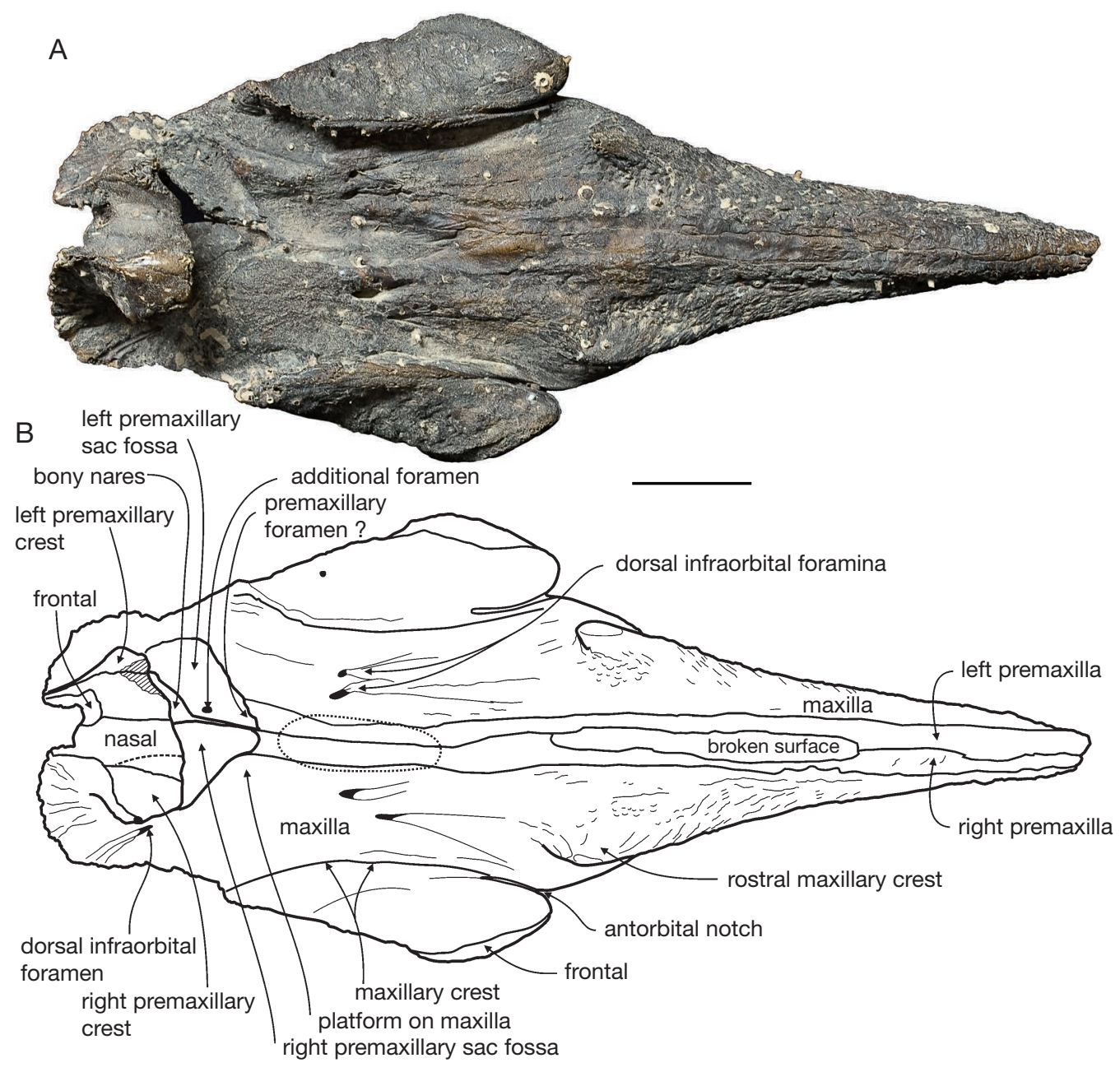

FIG. 14. - Skull of Imocetus piscatus n. gen., n. sp. (ML 1358, holotype): A, dorsal view; B, corresponding line drawing. Parallel lines indicate a break surface. Scale bar: $10 \mathrm{~cm}$.

trum base is also considerably wider in the holotype. The facial area, between the antorbital notch and the vertex, is very long. The vertex is proportionally low, overhanging the bony nares. The supraorbital area is only partly preserved and the basicranium is completely missing.

\section{Premaxilla}

On the anterior portion of the rostrum, the halfcylindrical robust premaxillae display a sutural contact above the mesorostral groove. Their medial suture is sinuous on the holotype and more rectilinear in ML 1359 (not preserved in ML 1360). $195 \mathrm{~mm}$ posterior to the apex of the rostrum of the holotype, an artificial medial opening between the superficial layers of the premaxillae exposes bone that we interpret as deeper regions of the premaxillae. Alternatively this element could correspond to the thickened vomer, but we prefer the first hypothesis taking into account the anteriorly open mesorostral groove. Considering the preserved parts, the premaxillae seem considerably thicker on the rostrum of ML 1359 than in the holotype, and even more than in ML 


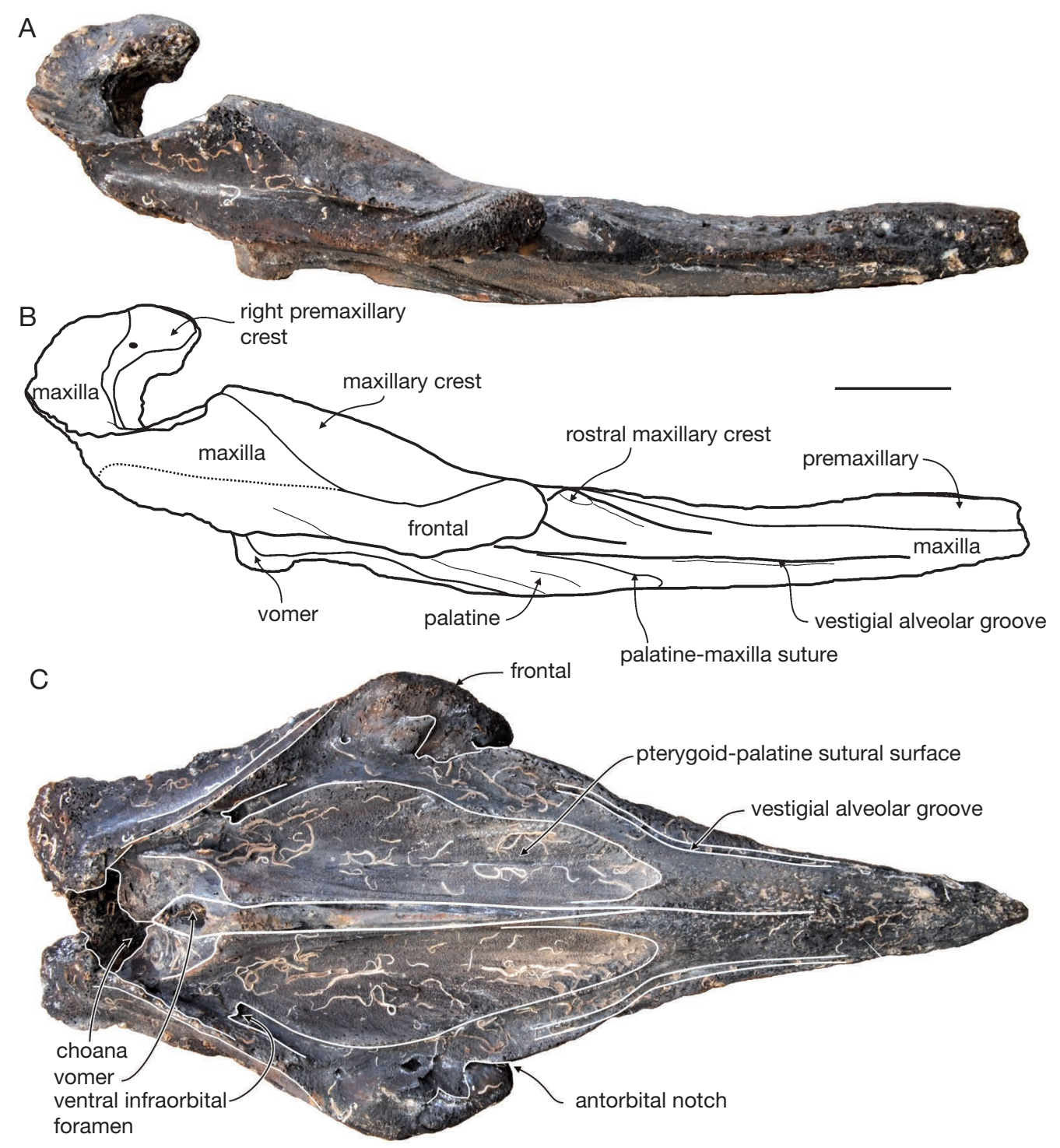

FIG. 15. - Skull of Imocetus piscatus n. gen., n. sp. (ML 1358, holotype): A, lateral view; B, corresponding line drawing; C, ventral view. Scale bar: $10 \mathrm{~cm}$.

1360. From the level of the antorbital notch, the premaxillae descend in a depression between the more prominent maxillae, until the premaxillary sac fossae. This depression seems homologous to the prenarial basin described in Beneziphius, Messapicetus, and Ziphirostrum (Lambert 2005; Bianucci et al. 2010). The premaxillary sac fos- sae, only well preserved on the holotype, are even more depressed compared to the maxillae, with a distinctly concave surface. The posteromedial portion of the right fossa is slightly elevated. The left fossa is lower than the right, and narrower. However, the asymmetry at this level is less pronounced than in Caviziphius, Globicetus 


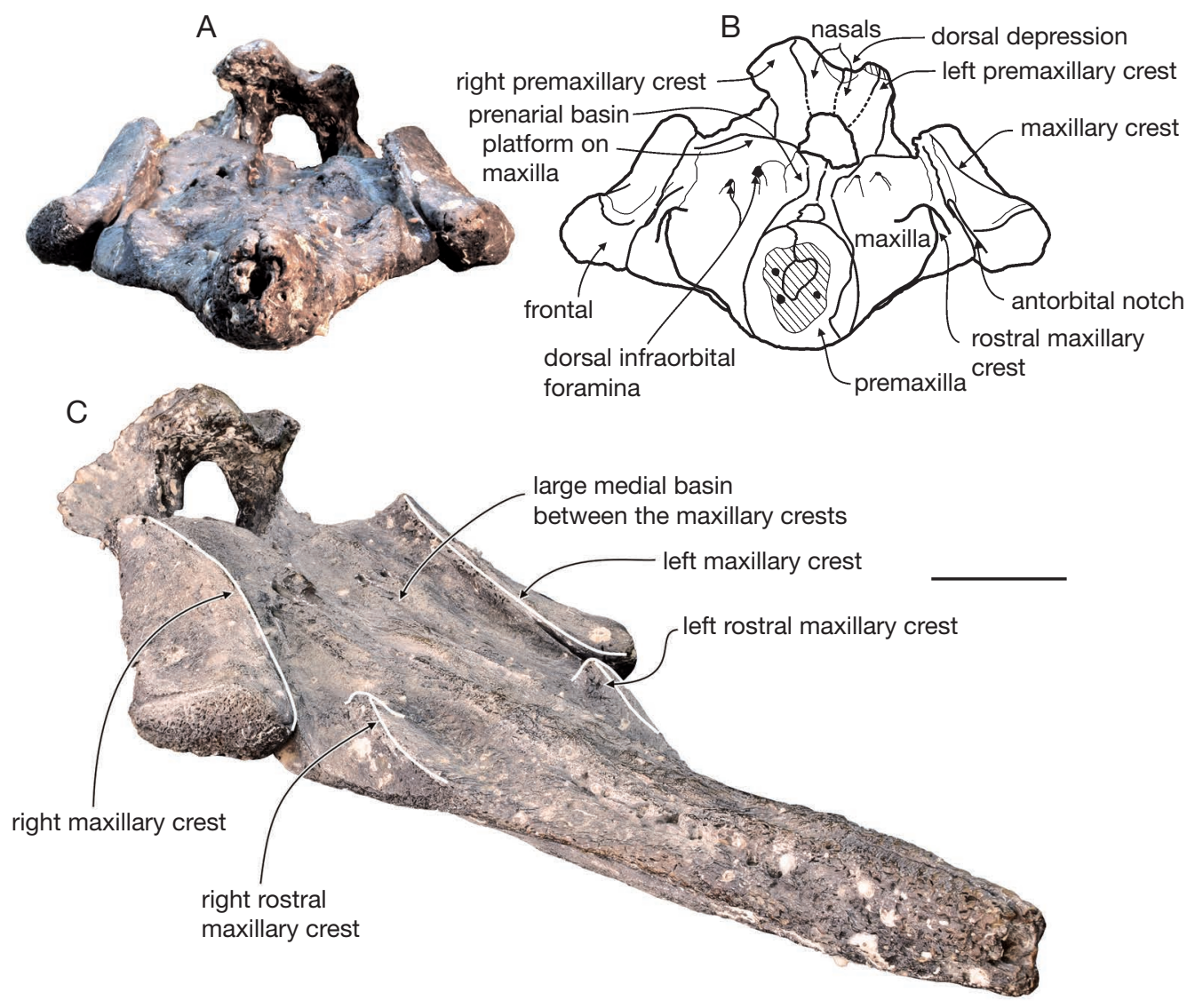

FIG. 16. - Skull of Imocetus piscatus n. gen., n. sp. (ML 1358, holotype): A, anterior view; B, corresponding line drawing; C, anterolateral view. Parallel lines indicate a break surface. Scale bar: $10 \mathrm{~cm}$.

n. gen., and Tusciziphius. If present (area partly covered with phosphorite concretions), right and left premaxillary foramina are close to each other and much more distant from the level of the antorbital notch than in any other known ziphiid, even more than in Hyperoodon. This condition stresses the unusual elongation of the facial area between antorbital notches and bony nares in Imocetus $\mathrm{n}$. gen. An additional foramen is present on the medial margin of the left premaxillary sac fossa of the holotype and ML 1360, in the same position as in Globicetus n. gen., Choneziphius leidyi n. sp., and Tusciziphius atlanticus n. sp.

The ascending process of the premaxilla is short and erected. Its upper part overhangs the corresponding premaxillary sac fossa. On the vertex, the premaxillary crests are highly asymmetric: the right crest is more voluminous, distinctly higher and more anteriorly bulging. Similar to Globicetus n. gen., the right premaxillary crest is posterolaterally directed whereas the left crest is anterolarally directed.

\section{Maxilla}

In dorsal view the maxilla is visible along the premaxilla on the whole length of the rostrum. On the second third of the rostrum, the lateral margin is acute. This margin only thickens considerably before the antorbital notch, in relation with the development of the rostral maxillary crest located medial to the notch. Compared to the holotype, this spur-like posterodorsally projecting 


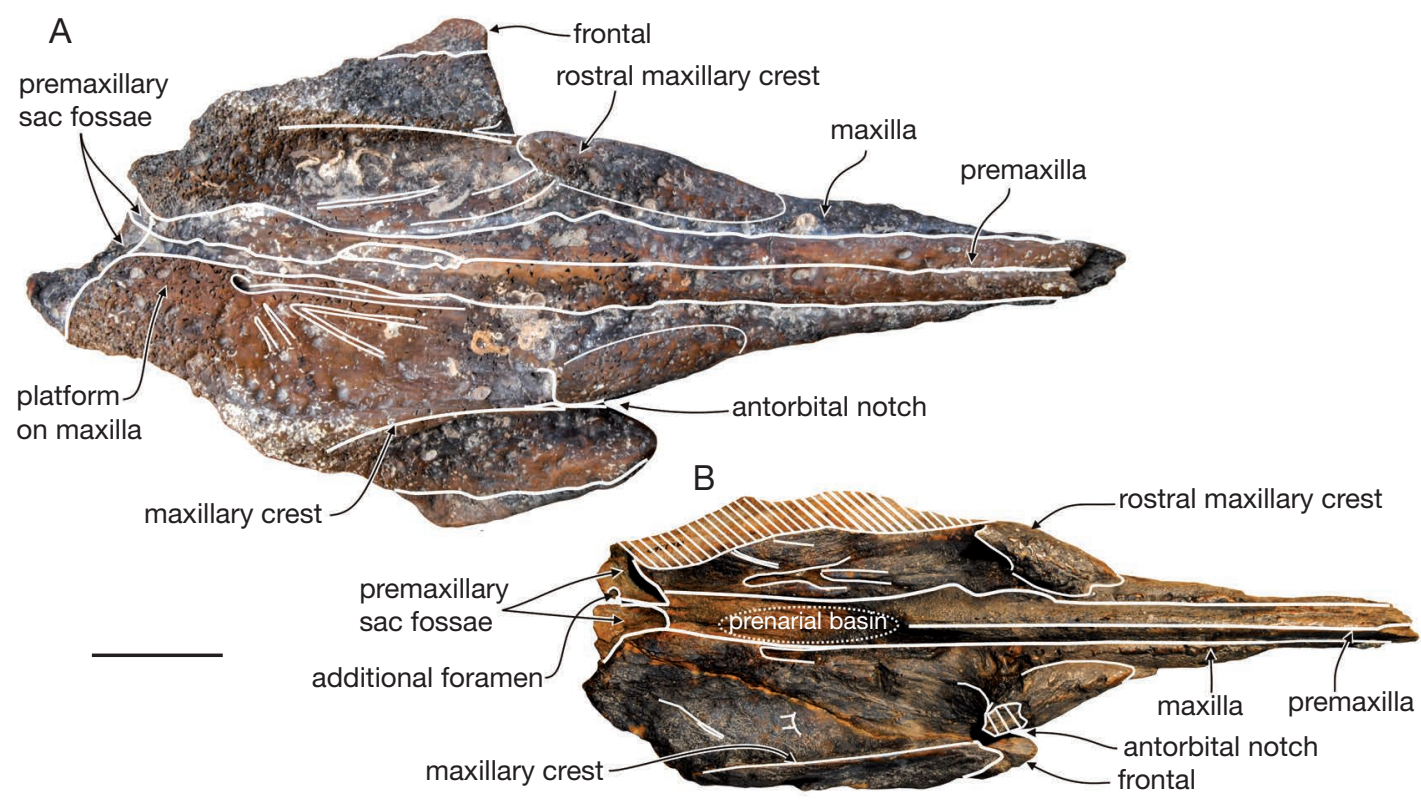

FIG. 17. - A, skull of Imocetus piscatus n. gen., n. sp. (ML 1359), dorsal view; B, skull of $I$. piscatus n. gen., n. sp. (ML 1360), dorsal view. Parallel lines indicate a break surface. Scale bar: $10 \mathrm{~cm}$.

crest is more laterally directed, larger, and more posteriorly located compared to the antorbital notch in ML 1359 and ML 1360. The crests are asymmetric in the holotype and ML 1359; in the former the left crest is slightly higher, whereas in the latter the incomplete right crest was originally more robust than the left crest. The antorbital notch is deep and narrow in the three specimens, medial to the robust and long preorbital process. The notch is more slit-like in the holotype and $\mathrm{V}$-shaped in the two other skulls. From the bottom of the notch, the maxilla forms an acute longitudinal crest on the supraorbital area of the skull. This crest is probably not homologous to the huge rostral crest observed medial to the antorbital notch in adults of Hyperoodon spp. (see Mead \& Fordyce 2009 for terminology). This maxillary crest is rectilinear and posteriorly diverging in ML 1359 and ML 1360, whereas it is medially convex in dorsal view and slightly overhangs the medial area of the maxilla in the holotype. Right and left crests limit a vast and depressed facial area, where dorsal infraorbital foramina are present along the prenarial basin (two on each side of the holotype, one on each side of ML 1359 and ML 1360). In addition to these large foramina, the surface of the maxilla is covered with shallow and narrow anastomosed sulci and tiny foramina. Between the dorsal infraorbital foramina and the premaxillary sac fossa, the maxilla is distinctly thickened, forming a platform with a convex surface, much wider on the right side (and also more elevated on the right side of the holotype and ML 1359). The lateral flank of the maxillary crest is a wide and slightly concave surface with a steep slope. Due to the non-preserved lateral part of the supraorbital process, in lateral view the crest of the holotype displays a high triangular section.

No alveoli could be detected on the heavily postmortem worn alveolar groove. In relation with the anterior shift of the preorbital process and antorbital notch compared to other ziphiids, the position of the ventral infraorbital foramen is strongly modified. This foramen is about $200 \mathrm{~mm}$ posterior to the antorbital notch in the three specimens, whereas 
it is a short distance from the notch in other ziphiids. The foramen is followed anteriorly by a deep and long groove, edging the pterygoid sinus fossa laterally until the antorbital notch. The location of the ventral infraorbital foramen also gives a clue about the level of the non-preserved orbit. Indeed, in other ziphiids and other odontocetes the frontal groove and optic canal are posterior to the infraorbital foramen.

\section{Nasal}

The nasals are wide anteriorly. Each of them occupies a considerable portion of the corresponding premaxillary crest and the nasal-premaxilla suture reaches the anterior surface of the crest, a condition more similar to Hyperoodon. The part of the nasal thrusted in the premaxillary crest is more compact than the smoothly depressed medial area. The difference of compactness only partly explains this internasal fossa, extending posteriorly on the left frontal and maxilla. The premaxilla-nasal suture being hard to distinguish in this very ossified vertex, an alternative interpretation would be a more medial suture more similar to the condition in Globicetus n. gen. and Tusciziphius (hatched line in Fig. 14B).

\section{Frontal}

Only fragments of the frontals are preserved posterior to the nasals on the vertex. The frontal sends a short anterior projection between the nasals. In lateral view, the frontal is the main element of the robust anterior part of the preorbital process, covered by a thin sheet of maxilla. More posteriorly the bone is incomplete laterally; the whole orbit area is lost and the extent of the temporal fossa cannot be assessed.

\section{Vomer}

Our interpretation of the rostral bones suggests that the vomer does not fill the mesorostral groove of Imocetus n. gen., dorsally covered by the joined premaxillae.

\section{Palatine}

The palatine is preserved on its rostral portion in the three specimens. The palatine-maxilla suture is visible at some levels, but the best seen structure is the surface of suture with the lost pterygoid, marked by grooves, and limiting a large depression corre- sponding to the vast anterior part of the pterygoid sinus fossa. The palatine-pterygoid suture extends far anterior to the antorbital notch in the three specimens, even more in the holotype, which is characterized by a more posteriorly located notch.

\section{Lacrimal}

Fragments of the lacrimal are preserved on the holotype, but its original outline cannot be precisely drawn.

\section{REMARKS}

The significant morphological variations between the holotype and the more fragmentary referred specimens is interpreted here as due to intraspecific variation (possibly related to sexual dimorphism, see below); pending the discovery of new more complete specimens, we choose to maintain ML 1359 and ML 1360 in the same species as the holotype.

Despite similarities of Imocetus n. gen. with some hyperoodontines (nasal probably included in the premaxillary crest and reaching the anteromedial margin of the crest; excavation of the dorsomedial surface of the nasal; right premaxillary crest posterolaterally directed) and more specifically with Hyperoodon (low vertex overhanging the premaxillary sac fossae; premaxillary foramen posterior to the level of the antorbital notch), this new genus is interpreted here as a member of the subfamily Ziphiinae. Indeed, it shares with all ziphiines, except Izikoziphius and Ziphius, the medial fusion of the thickened premaxillae dorsally closing the mesorostral groove, with Globicetus n. gen. and Tusciziphius the extreme ossification and fusion of the vertex elements, and with Choneziphius, Globicetus n. gen., and T. atlanticus n. sp. the deep premaxillary sac fossae.

\section{Family ZIPHIIDAE Incertae sedis}

\section{Genus Caviziphius Bianucci \& Post, 2005}

TyPe AND ONLY SPECIES. - Caviziphius altirostris Bianucci \& Post, 2005, known from a single specimen from Steendorp (Belgium), probably late Miocene (Bianucci \& Post 2005). 


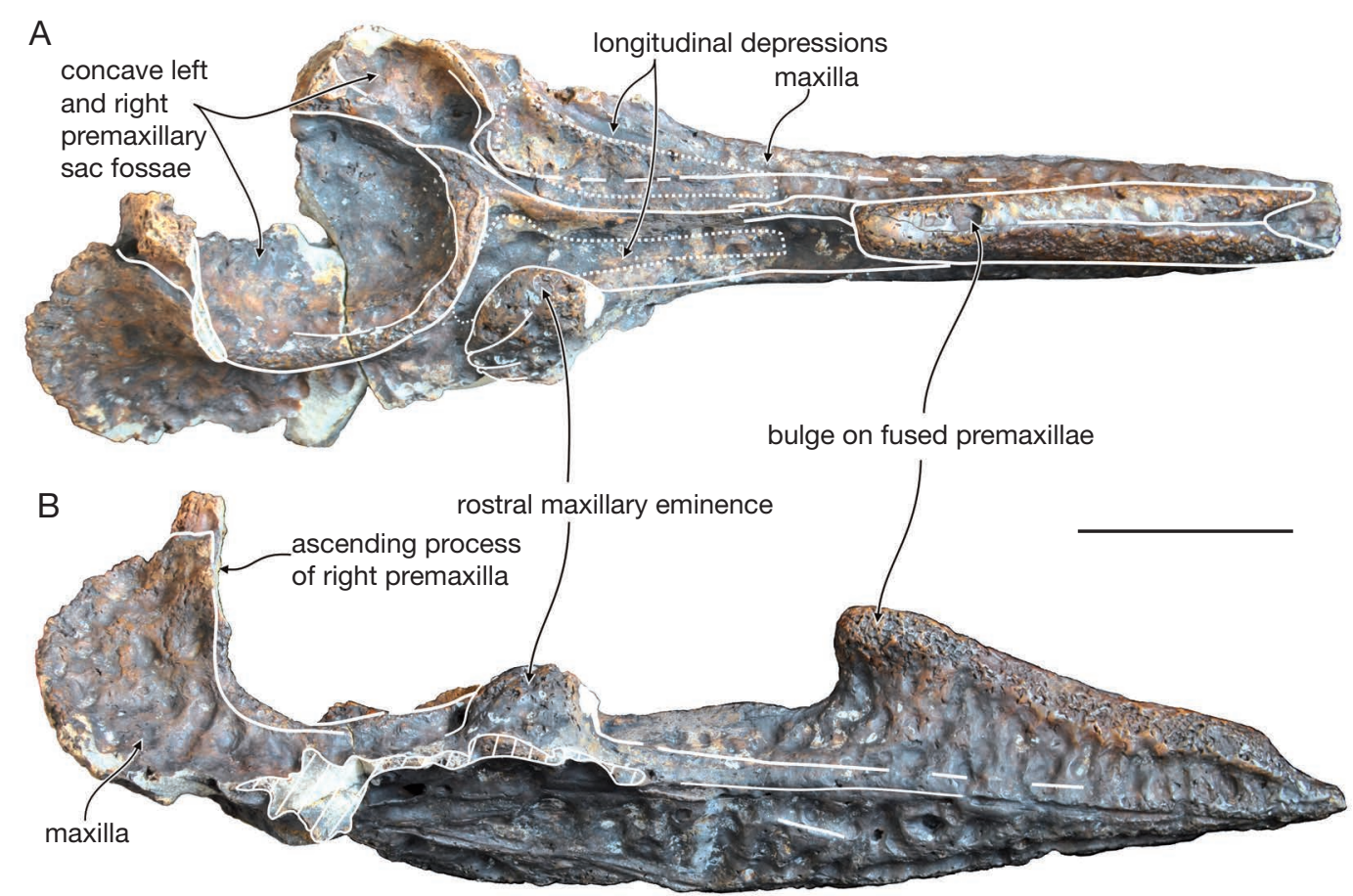

FIG. 18. - Skull of aff. Caviziphius sp. (SGHN MA0920): A, dorsal view; B, lateral view. Parallel lines indicate a break surface. Scale bar: $10 \mathrm{~cm}$.

\section{aff. Caviziphius sp.}

(Fig. 18)

REFERRED SPECIMEN. — SGHN MA0920, partial skull including rostrum and right part of facial area, Cortada fishing ground, off the Galician coast, depth of approximately $400-800 \mathrm{~m}, 43^{\circ} 36^{\prime} \mathrm{N}, 9^{\circ} 0^{\prime} \mathrm{W}$.

\section{DESCRIPTION}

The original shape of this badly preserved fragmentary skull might have been partially modified by an intense wear. The sutures between the bones are also almost completely obliterated. Nevertheless some typical features of the premaxilla and maxilla (medial rostral premaxillary bulge, strongly asymmetric premaxillary sac fossae, and prominent right rostral maxillary eminence) are conspicuous and allow a relevant comparison with other ziphiids.

\section{Premaxilla}

In dorsal view, the premaxillae are medially sutured for all their rostral length except for the apical $55 \mathrm{~mm}$ portion, where the premaxillae abruptly diverge and leave the mesorostral groove dorsally open. From the anteriormost point of their junction, the height of the premaxillae increases progressively, reaching an elevation of $78 \mathrm{~mm}$ above the maxilla at $186 \mathrm{~mm}$ from the anterior margin of the right premaxillary sac fossa, forming a protuberant bulge. Posteriorly, the height of the premaxillae decreases abruptly, generating a clear step on the dorsal outline of the rostrum seen in lateral view. On the whole, this premaxillary bulge is similar to the bulge observed in some skulls of Tusciziphius atlanticus n. sp. (holotype, SGHN MA0632, and SGHN MA0644) even if its posterior margin is distinctly more anterior. In fact, the distance from the posterior margin of the bulge and the anterior margin of the premaxillary sac fossa is $186 \mathrm{~mm}$ in SGHN MA0920, whereas it varies from 81 to $128 \mathrm{~mm}$ in T. atlanticus n. sp. A similar anterior premaxillary bulge is present in a partial skull 
from the Neogene of Antwerp, Belgium (NMB 002), referred by Lambert (2005: fig. 27A-C) to Ziphiidae aff. Eboroziphius.

Between the bulge and the premaxillary sac fossae, the premaxillae form a shallow medial elevation laterally delimited by two longitudinal depressions. A similar architecture is present in T. atlanticus n. sp. (even if this area is anteroposteriorly shorter), NMB 002, Eboroziphius coelops Leidy, 1876, and Caviziphius altirostris. The incompletely preserved premaxillary sac fossae are strongly asymmetric (ratio between maximum width of left and right fossae approximately 0.5 ) and deeply excavated, even more than in T. crispus. The fossae are separated by a narrow septum corresponding to the medial overlap of the premaxillae. For these characters, the premaxillary sac fossae are similar to those of NMB 002, Caviziphius, E. coelops, and Pelycorhamphus pertortus Cope, 1895 (see Lambert 2005: fig. 28). It is important to outline that the holotypes and only referred specimens of $E$. coelops and $P$. pertortus are fragmentary and considerably worn; consequently we restrict the genera to their type-species and the typespecies to their holotypes, and consider them as incertae sedis.

Only the incomplete ascending portion of the right premaxilla is preserved. It abruptly rises from the level of the premaxillary sac fossa; consequently, in lateral view, the outline of the anterior margin of the vertex displays a deep concavity, followed ventrally by a semicircular deep excavation corresponding to the premaxillary sac fossa. A similar lateral profile is observed in Caviziphius.

Although no premaxillary crest is preserved, the thin broken surface at the posterior end of the right ascending process suggests that the right crest was not massive and wide as seen in Globicetus n. gen. and Tusciziphius. Nevertheless, the right premaxillary crest of Caviziphius, even if not completely preserved, seems to have been more robust than in SGHN MA0920, judging from the wider break surface on the ascending process of the right premaxilla of the holotype and only referred specimen.

\section{Maxilla}

Due to the incompleteness and the strong erosion, the maxilla does not show any significant features, with the exception of a prominent right rostral maxillary eminence. Roughly located at the rostrum base, this semicircular crest is tilted medially. A similar crest is present in several skulls of T. atlanticus n. sp. and in NMB 002.

\section{REMARKS}

SGHN MA0920 shares with some skulls of Tusciziphius atlanticus $\mathrm{n}$. sp. and the fragmentary skull NMB 002 the medial bulge on the fused premaxillae, the strongly asymmetric premaxillary sac fossae, and the prominent right rostral maxillary eminence. Considering the deep excavation of both premaxillary sac fossae, the anterior location of the premaxillary bulge, and the diverging premaxillae near the anterior end of the bulge, SGHN MA0920 is more similar to NMB 002 than to T. atlanticus n. sp. SGHN MA0920 also shares with Caviziphius the deeply excavated asymmetric premaxillary sac fossae, the longitudinal depressions that laterally margin the shallow medial elevation of the sutured premaxillae at the rostrum base, and the abrupt elevation of the ascending process of the right premaxilla. Unfortunately the anterior part of the rostrum and the antorbital area of the maxillae are not preserved in the holotype and only referred specimen of Caviziphius altirostris (see Bianucci \& Post 2005); consequently it is not possible to establish if the premaxillary bulge and the prominent right rostral maxillary eminence are also present in the latter. Nevertheless, considering that the holotype of $C$. altirostris and NMB 002 are nearly identical for the parts preserved in both specimens and show similar dimensions, it is likely that both these incomplete skulls belong to the same species. Furthermore they were collected in the same area (Antwerp). If this hypothesis is confirmed with future discoveries, $C$. altirostris will be redefined with the combination of the characters of the holotype and NMB 002. The only significant differences between SGHN MA0920 and these two skulls from Antwerp are the smaller size and probably the thinner right premaxillary crest. 


\section{"Messapicetus clade"}

Genus Ziphirostrum du Bus, 1868

TyPE SPECIES. - Ziphirostrum marginatum du Bus, 1868, from Antwerp (Belgium), late Miocene (Lambert 2005).

OTHER SPECIES INCLUDED. - Ziphirostrum recurvus (du Bus, 1968) and Z. turniense du Bus, 1868.

\section{aff. Ziphirostrum sp.}

(Fig. 19; Table 5)

REFERRED SPECIMEN. — SGHN MA0936, partial skull including rostrum and left part of facial area, A Selva fishing ground, depth of approximately $500 \mathrm{~m}$, off the Galician coast, $44^{\circ} 10^{\prime} \mathrm{N}, 08^{\circ} 40^{\prime} \mathrm{W}$.

\section{DESCRIPTION}

The rostrum of this medium-size ziphiid is narrow and elongated, with size and proportions close to Ziphirostrum turniense (see Lambert 2005).

\section{Premaxilla}

The premaxillae are distinctly swollen on the rostrum, contacting each other dorsomedially above the hollow mesorostral groove for most of the rostral length. The nearly fused medial suture is asymmetric, shifted to the right side on the posterior half of the rostrum. A similar asymmetry has been noted, but on the other side, on an isolated ziphiid rostrum from the Miocene of Maryland, USA (Lambert et al. 2010). In lateral view, the maximum height and width of the premaxilla is more anterior than in $Z$. marginatum, more similar to $Z$. turniense. From mid-length of the rostrum, the premaxilla narrows considerably, and a medial separation appears $110 \mathrm{~mm}$ anterior to the level of the antorbital notch, with a progressive descent of the premaxilla in the prenarial basin, a feature absent in Choneziphius. The extent and depth of the basin is again more similar to $Z$. turniense, shallower than in $Z$. marginatum. Less anteriorly located than in the latter, the premaxillary foramen is on the floor of the basin, slightly anterior to the prominental notch. The partly preserved surface of the left premaxillary sac fossa is transversly convex, as in Ziphirostrum, differing from the concave surface in Choneziphius and related taxa. The ascent towards the vertex is not abrupt.

\section{Maxilla}

Even if the anterior part of the maxilla-premaxilla suture is difficult to detect, the anterior end of the maxilla is located 50-60 mm from the apex of the rostrum. Barely visible in dorsal view for the anterior half of the rostrum, the maxilla considerably widens towards the prominental notch, forming an elongated triangular surface. The posterior part of this surface, along the prenarial basin, displays a steep slope, with an elevated and thin lateral margin, more similar to $Z$. turniense. Considerably wider on the right side than on the left, the triangular surface is covered with numerous and high excrescences, a character found in Choneziphius, but also in Beneziphius and an isolated ziphiid rostrum from the Neogene of the North Sea (see Lambert 2005: fig. 26). The prominental notch and maxillary tubercle are conspicuous; this area is not well preserved in any specimen of $Z$. turniense. No marked maxillary crest extends posteriorly from the maxillary tubercle, differing from Choneziphius.

The alveolar groove is vestigial, with shallow remains of alveoli still visible, a condition observed in several specimens of $Z$. marginatum and $Z$. turniense.

\section{Palatine}

The palatine is preserved at the rostrum base, with a maxilla-palatine suture easy to distinguish. The rounded anterior end of the palatine is $130 \mathrm{~mm}$ anterior to the antorbital notch. An abrupt step in the surface of the palatine indicates the suture with the lost pterygoid.

\section{REMARKS}

Except for the development of excrescences on the dorsal surface of the maxilla on the posterior half of the rostrum and the distinct asymmetry of the premaxillae on the rostrum, this specimen is similar to the two specimens from the Neogene of the North Sea referred to Ziphirostrum turniense. The low diagnostic value of the excrescences on the maxilla has previously been demonstrated (Lambert 2005) and the development of the premaxillae on the rostrum is known to vary within one species. The main features differentiating $Z$. turniense from the better-known $Z$. marginatum are observed here: maximum width and height of the premaxillae at 
TABLE 5. - Measurements (in $\mathrm{mm}$ ) on the skull of aff. Ziphirostrum sp. SGHN MA0936 from the Atlantic Ocean floor off the Iberian Peninsula. Abbreviation: e, estimate.

\begin{tabular}{lc}
\hline & SGHN MA0936 \\
\hline Rostrum length & 557 \\
Distance from apex of rostrum to bony nares & e635 \\
Width of rostrum at mid-length & 71 \\
Width of premaxillae at mid-length of rostrum & 49 \\
Height of rostrum at mid-length & 90 \\
Width of rostrum base at prominental notch & $\mathrm{e} 120$ \\
Width of rostrum base at antorbital notch & $\mathrm{e} 208$ \\
Distance rostrum base - anterior apex of palatine & 130 \\
Preorbital width of skull & e314 \\
Longitudinal distance left premaxillary foramen-rostrum base & 40 \\
Width of left premaxillary sac fossa & 49 \\
\hline
\end{tabular}

mid-length of the rostrum, shallower prenarial basin, with dorsal exposure of the maxillae wider and more steeply sloping along the basin. The third species of the genus, $Z$. recurvus, is characterized by a more elevated rostrum with a complete filling of the mesorostral groove by the vomer, a feature lacking here. Because this specimen originates from a remote area, and because the vertex is lacking, as in specimens of $Z$. turniense and $Z$. recurvus, we prefer to maintain the attribution Ziphiidae aff. Ziphirostrum sp., pending the discovery of more complete specimens.

\section{PHYLOGENY}

To explore the phylogenetic relationships of the new ziphiids described here (Choneziphius leidyi n. sp., Imocetus piscatus n. gen., n. sp., Globicetus hiberus n. gen., n. sp., and Tusciziphius atlanticus n. sp.), we included the new taxa in the matrix of 29 morphological characters published by Bianucci et al. (2010) and undertook a similar cladistic analysis, using the same outgroups (the squalodontid Squalodon and the eurhinodelphinid Eurhinodelphis). The only change in the matrix is the addition of a new state (3) for the unordered character 10 (premaxillary crest direction): left crest anterolaterally directed and right crest posterolaterally directed, a condition observed in Globicetus n. gen. and Imocetus n. gen. The coding of characters for the Iberian new taxa is given in the Appendix 1.
The cladistic analysis was achieved with the software PAUP (version 4.0b10; Swofford 2001), using the Branch-and-bound algorithm with the homoplastic characters down-weighted using the default value of 3 for the constant $k$ of the Goloboff method (1993). The analysis produced 875 equally parsimonious trees, with tree length 94, Goloboff fit-20.98, Consistency Index (CI) 0.53 and Retention Index (RI) 0.72 . The consensus tree (Fig. 20) displays the same general topology as in Bianucci et al. (2010). All the Iberian ziphiids are placed inside the Ziphiinae. Choneziphius leidyi n. sp. appears as sister taxon of $C$. planirostris, the species coded in the previous analysis for the genus Choneziphius. The unresolved relationships between T. atlanticus n. sp. and T. crispus are probably due to the incompleteness of the holotype and only referred specimen of T. crispus. Nevertheless, both species are more basal than the Choneziphius + Izikoziphius + Ziphius clade, similar to the position of T. crispus in Bianucci et al. (2010). Globicetus n. gen. and Imocetus n. gen. have a more basal position inside the Ziphiinae, redefined here (see the emended diagnosis above) with the inclusion of these two new genera.

\section{INTRASPECIFIC VARIATION}

Significant morphological variation, considered as possibly related to sexual dimorphism and/or ontogeny, is observed in the samples of skulls referred to Tusciziphius atlanticus n. sp. and Imocetus piscatus n. gen., n. sp. 


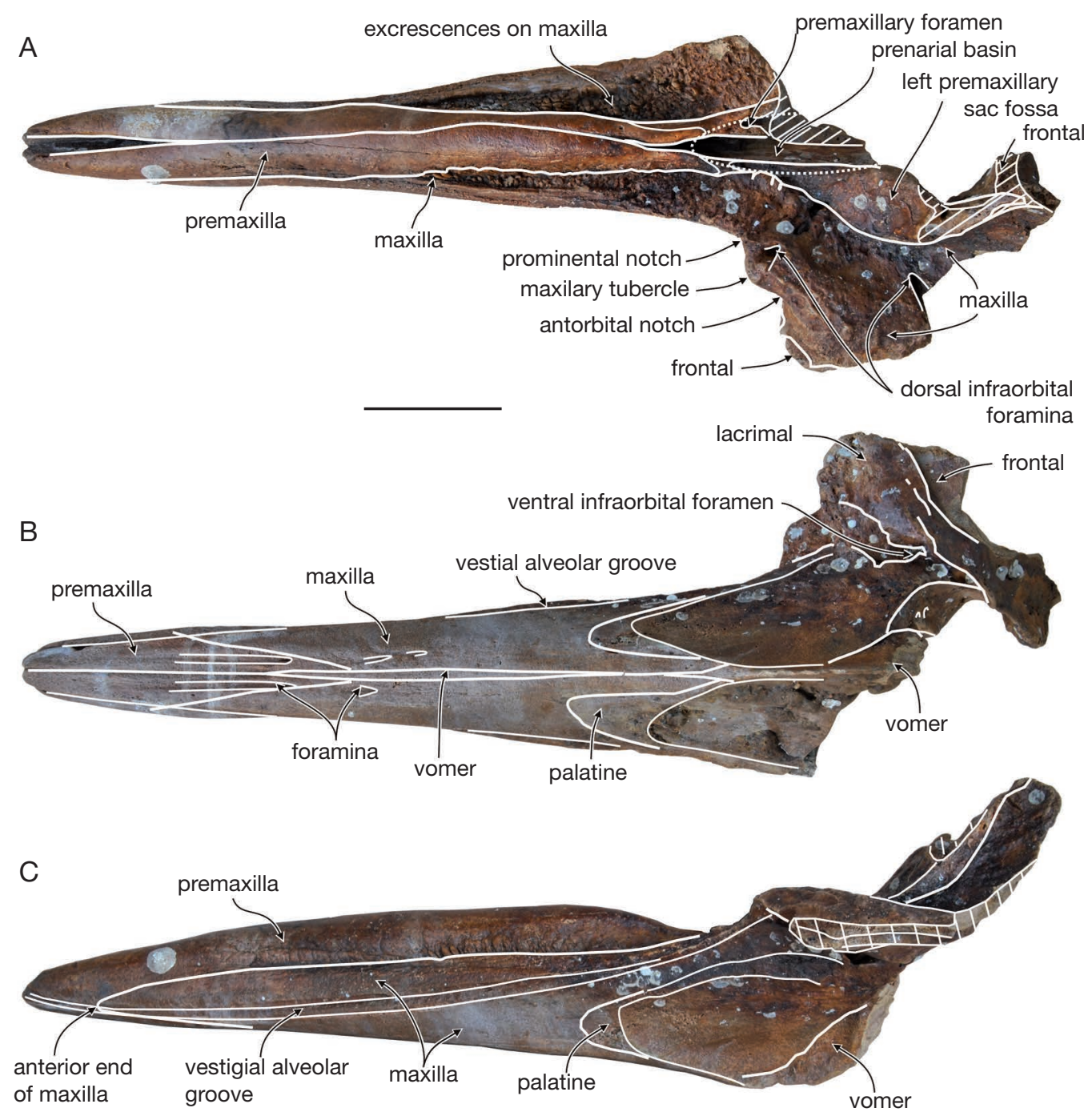

FIG. 19. - Skull of aff. Ziphirostrum sp. (SGHN MA0936): A, dorsal view; B, ventral view; C, lateral view. Parallel lines indicate a break surface. Scale bar: $10 \mathrm{~cm}$.

The intraspecific variation observed at the level of the medial premaxillary bulge within the species T. atlanticus n. sp. is very conspicuous, the most significant found until now in a fossil ziphiid considering the range of sizes for the concerned element. Interestingly, the development and extension of the medial premaxillary bulge shows a correlation with the development of rostral maxillary eminences. Indeed, the speci- mens that display a high medial premaxillary bulge (holotype, SGHN MA0644, and SGHN MA0632) also bear rostral maxillary eminences, more developed on the right side. Such a variation could be related to sexual dimorphism. In several extant ziphiids, a high intraspecific variation related to sex and age has been reported: filling of the mesorostral groove by the vomer more pronounced in adult males of Mesoplodon 


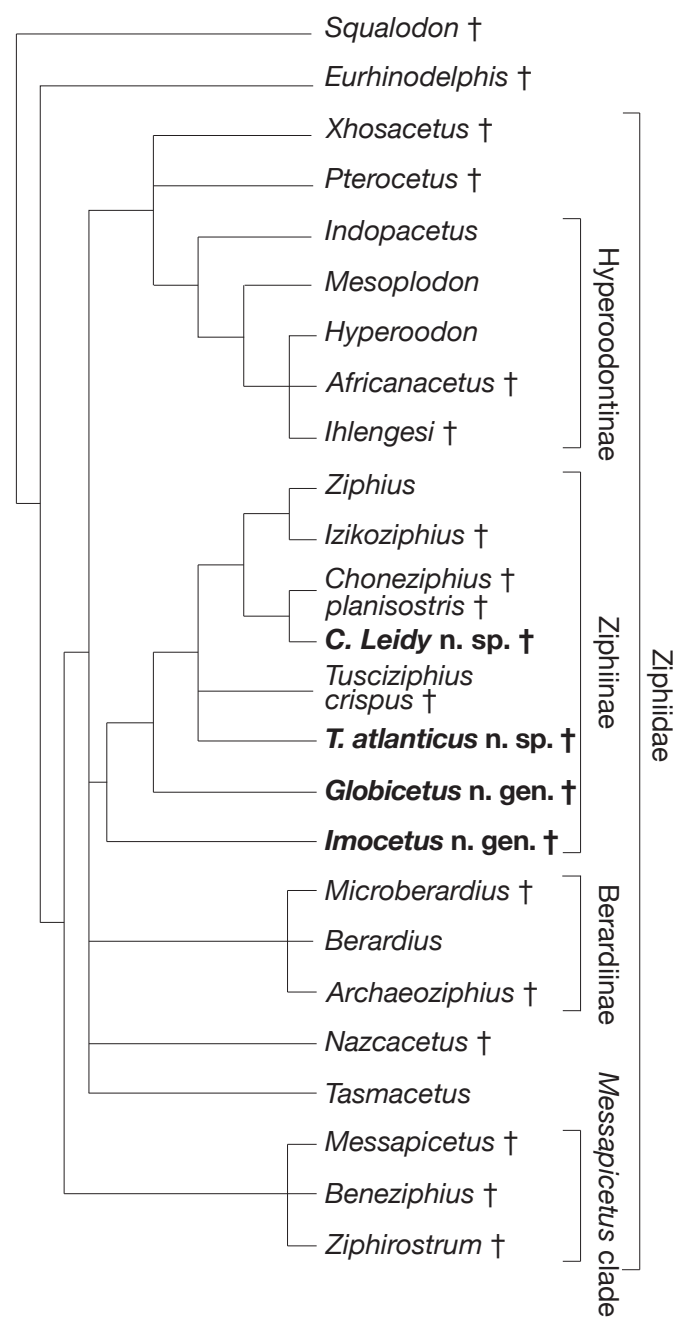

FIG. 20. - Consensus tree of 875 equally parsimonious cladograms showing the relationships of the lberian fossil ziphiids (in bold) with other fossil and extant ziphiid genera. Tree length 94, Goloboff fit - 20.98, Cl 0.53 and RI 0.72. See Bianucci et al. (2011) for the description of characters and matrix, and Appendix 1 for the coding of characters of taxa not included in that previous analysis. $\mathbf{t}$, strictly fossil taxa.

spp. and Ziphius cavirostris Cuvier, 1823, further development of the prenarial basin in adult males of $Z$. cavirostris, much higher rostral maxillary crests in adult males of Hyperoodon ampullatus (Forster, 1770), and larger mandibular tusks in adult males of many extant ziphiids, and possibly fossil ziphiids (e.g., Heyning 1984, 1989a, b; Mead 1989a, b; MacLeod \& Her- man 2004; Lambert et al. 2010). Based on the development of the medial premaxillary bulge and the rostral maxillary eminences in $T$. atlanticus n. sp., we propose that the holotype, SGHN MA0644, SGHN MA0632, and SGHN MA0926 are males, whereas the paratype and SGHN MA0914 are interpreted as females or immature males, by analogy with extant ziphiids, especially $H$. ampullatus. In adult males of the latter, further development of the rostral maxillary crests starts at the onset of sexual maturity, leading to a larger size, massive proportions, and a flattened anterodorsal surface (Hardy 2005). Similarly the different degrees of development of the medial premaxillary bulge and of the rostral maxillary eminences observed in T. atlanticus n. sp. might be explained by sexual dimorphism and maturity.

In I. piscatus n. gen., n. sp., the significant morphological variation observed between the holotype and the more fragmentarily known referred specimens is also related to bony structures influenced by high sexual dimorphism in several modern ziphiids. Indeed, the most striking difference, namely the length of the preorbital process and the related position of the antorbital notch, might be linked to the development of the maxillary crest on the supraorbital process. This crest forms a lateral boundary to a wide facial depression seemingly analogous (but not homologous) to the wide prenarial basin of adult male $Z$. cavirostris (see Heyning 1989a; Cranford et al. 2008). Nevertheless, a larger sample for I. piscatus n. gen., n. sp. would be necessary to give a firmer interpretation for this observed variation.

\section{FUNCTIONAL ANATOMY}

From a functional point of view, bony crests, depressions, and prominences in the facial area of modern odontocetes are often demonstrated to be related to soft anatomy elements of the forehead (facial and rostral muscles, blowhole, melon, nasal passages, nasal sacs, and other structures associated with echolocation; see e.g., 
Cranford et al. 2008; Huggenberger et al. 2009). For example, the deep prenarial basin of adult males of Ziphius cavirostris contains a fat body usually identified as the melon (Heyning 1989a), but it has been recently differentiated from the melon as the anterior spermaceti organ (Cranford et al. 2008). Low maxillary crests in the supraorbital region of odontocetes correspond to areas of origin for facial muscles (Mead 1975; Heyning 1989a; Mead \& Fordyce 2009), acting on the nasal passages, blowhole, and melon. In addition, the lateral and medial surfaces of the huge rostral maxillary crests of Hyperoodon spp. are areas of origin for several facial and rostral muscles (Schenkkan 1973), even if this is much likely not the unique function of the crests (see Mead 1989a; Gowans \& Rendell 1999; Hardy 2005). The premaxillary eminences anterolateral to the bony nares of Phocoena bring the overlying premaxillary sac fossae, potential sound reflectors, closer to the acoustic pathway (Huggenberger et al. 2009).

\section{ROSTRAL PREMAXILLARY THICKENING}

Several functions have been proposed for the varied conditions of pachyosteosclerotic rostral bones in extinct and extant ziphiids (Heyning 1984; Buffrénil \& Casinos 1995; Zioupos et al. 1997; MacLeod 2002). Until now, no single functional interpretation explains the whole diversity of morphologies observed (Buffrénil \& Lambert 2011; Lambert et al. 2011). The spherical prominence of Globicetus n. gen. and the medial bulge of Tusciziphius atlanticus $\mathrm{n}$. sp. are certainly some of the most bizarre rostral elements described to date for odontocetes, and the question of their potential function as well as the question of their influence on, or link with, the echolocation system are both difficult to answer.

In lateral view, the anterior margin of the spheroid in Globicetus n. gen. and of the bulge in T. atlanticus n. sp. occupies a position roughly similar to the anterior surface of the elevated rostral maxillary crests of extant Hyperoodon. In addition to being areas of origin for facial muscles (Heyning 1989a), the crests of H. ampullatus are thought to be used as weapons during head-butting encounters between adult males; additionally, they might also provide a protection for the soft tissues located posterior and between them, mostly the melon, during impacts (Gowans \& Rendell 1999; Hardy 2005).

A similar function could be proposed in Globicetus n. gen. and T. atlanticus n. sp. For the latter, it would be corroborated by the sexual dimorphism interpretation given above. However, contrasting with the spongy aspect of the bone in Hyperoodon (Hardy 2005; Lambert et al. 2011), the superficial layers of the spheroid of Globicetus n. gen. are made of very compact bone. Similarly, high compactness has been detected through preliminary macroscopic observations of transverse sections of the bulge in T. atlanticus $n$. sp., suggesting very different mechanical properties for this element (see discussion for Mesoplodon densirostris Blainville, 1817 in Buffrénil et al. 2000). Another type of function might be related to the deep-diving habit of extant ziphiids. Indeed, this voluminous element, made of compact bone, distinctly increases the weight of the skull, particularly in Globicetus n. gen. Such a feature has been proposed to help maintaining a vertical position in the water during descents towards feeding areas in other ziphiids (Buffrénil \& Casinos 1995; Zioupos et al. 1997), but ecological data on extant ziphiids do not explain for now the observed sexual dimorphism. A combination of functions might likely better reflect the diversity of rostrum forms observed (Buffrénil et al. 2000; Lambert et al. 2011). It is clear that additional analyses will be necessary to continue the discussion of the potential function(s) of the spheroid and of the bulge. The examination of the inner bone organization, through Computed Tomography scanning (CT scan) or ground sections of more fragmentary specimens, will bring additional data about the compactness, mechanical properties, and growth process of these unusual bony structures.

In addition to the question of its function, the spheroid of Globicetus n. gen., and in a lesser extent the narrower medial bulge of T. atlanticus n. sp., must obviously be considered in the framework of echolocation. Indeed, in odontocetes the echo- 
location sounds are thought to be produced in the area of the forehead roughly vertical to the bony nares, and transmitted forwards via a lowdensity pathway including the melon (Cranford et al. 1996, 2008). If the lateral view of the skull of Globicetus is compared to a CT scan of the head of the extant Ziphius (see Cranford et al. 2008: fig. 6), the spheroid of Globicetus n. gen. is only slightly more anterior than the position of the melon in Ziphius, and it is nearly as high. Therefore, there is only little space for the melon in Globicetus n. gen., and this soft tissue was certainly located more posterodorsally than in other ziphiids. In Hyperoodon, the melon has been described as elongated, situated between the rostral maxillary crests (Schenkkan 1973), a condition impossible in Globicetus n. gen. In the latter, the only way for the transmission of sounds is dorsal to the spheroid, which must be considered as an unsurpassable obstacle, an acoustic reflector, considering its high compactness (acoustic impedance mismatch with surrounding soft tissues, including the phonic lips area, where the sounds are produced, and the melon, through which the sounds are transmitted). This implies that the sounds were produced at a level high enough above the level of the dorsal surface of the spheroid.

\section{ROSTRAL MAXILLARY CREST}

For the rostral maxillary eminences and crests of Tusciziphius atlanticus n. sp. and Imocetus n. gen., n. sp., a similar functional explanation might be proposed: protection of forehead soft tissues facing more lateral impacts. However, the supraorbital region and rostrum base of odontocetes is mainly an area of origin for facial and rostral muscles, acting on the air sac system, the blowhole, the nasal plugs, and the melon (Heyning 1989a). The development of high crests might provide surfaces for the attachment of muscles, with a different direction of action. Considering the posterodorsal direction of the pointed spurlike rostral maxillary crest in Imocetus n. gen., muscles originating there reached a relatively posterior region of the forehead, possibly the posterior part of the melon. In various odon- tocetes, rostral muscles have been proposed to modulate the shape of the melon, influencing therefore the shape of the sound beam (Mead 1975; Au 1993; Huggenberger et al. 2009). In T. atlanticus $\mathrm{n}$. sp., the asymmetry of the crests (right crest considerably larger than left crest) would mirror the asymmetry of the forehead soft tissues observed in extant ziphiids, as well as in other odontocetes (Heyning 1989a; Cranford et al. 1996). A similar argument was proposed to explain the asymmetry in the development of excrescencies on both sides of the rostrum base in Choneziphius planirostris, presumably for the attachment of rostral muscles (Lambert 2005).

\section{FACIAL BASIN AND MAXILLARY CREST}

By comparison with the odontocetes displaying the most developed facial basin (supracranial basin in the sperm whale Physeter and prenarial basin in adult males of Ziphius), the large facial depression of Imocetus n. gen. probably contained the main portion of the fat bodies of the forehead (anterior spermaceti organ and/or melon). The unusual length of the facial area, linked to the derived anterior shift of the preorbital process, might be an indication of an enlarged fat body. In modern odontocetes, melon and spermaceti organ are both considered as low density preferential acoustic pathways, for the transmission and shaping of echolocation sound beams (reviewed in Cranford et al. 1996; Cranford 1999). The lateral flank of the long and high maxillary crest on the supraorbital process of Imocetus was probably an important area of origin for facial muscles. In the modern Mesoplodon carlhubbsi Moore, 1963, Heyning (1989a: figs 6-8) describes two longitudinal ridges on the supraorbital process: the lateral ridge, ending anteriorly as the antorbital tubercle, and the maxillary ridge, ending anteriorly as the maxillary prominence (or maxillary tubercle). Possibly corresponding to the supraorbital crest of other odontocetes, the lateral ridge is the site of origin for the pars anteroexternus of the $m$. maxillonasolabialis, whereas the maxillary ridge (= maxillary crest) is the site of lateral origin of the much larger pars anterointernus (Heyning 1989a; synonymies in Mead \& Fordyce 2009). It is more likely that 
the maxillary crest of n. gen., much higher than the ridges described in $M$. carlhubbsi, was the site of origin for the pars anterointernus. In modern ziphiids, fibers of this muscle insert on the nasal passages (Heyning 1989a).

\section{PALAEOBIOGEOGRAPHY AND PALAEOECOLOGY}

The 18 diagnostic partial skulls recovered from the Atlantic Ocean floor off the coasts of Spain and Portugal are referred to the six genera (two of them are new) and four species (all of them are new) listed below.

- Choneziphius leidyi n. sp. (three specimens from Galicia, 2 from Portugal);

- Tusciziphius atlanticus n. sp. (four from Galicia, one from Portugal);

- Globicetus hiberus n. gen., n. sp. (two from Galicia, one from Portugal);

- Imocetus piscatus n. gen., n. sp. (three from Portugal);

- aff. Caviziphius sp. (one from Galicia);

- aff. Ziphirostrum sp. (one from Galicia).

Several other ziphiid skulls, including two specimens trawled off the Galician coast and identified by us as belonging to I. piscatus n. gen., n. sp., are not described here in detail because they are kept in private collections.

In addition to the fossil ziphiids, the following fragmentary remains were also collected: five isolated teeth of stem physeteroids; three periotics, eight tympanic bullae, and a skull fragment all belonging to mysticetes (Balaenidae, Balaenopteridae and Cetotheriidae); and several vertebrae and teeth of sharks (some belonging to Cosmopolitodus hastalis and Carcharocles megalodon).

On the whole, the fossil ziphiid associations of Galicia and Portugal show the same composition, with the exception of two fragmentary skulls collected off the Galician coast and referred to aff. Caviziphius sp. and aff. Ziphirostrum sp. A similar condition is present today as the ziphiid communities, and more generally the cetacean assemblages, off Galicia and Portugal are substantially similar (Covelo \& Martínez 2001). Even if we cannot demonstrate that all these taxa lived at the same time, this past ziphiid diversity is roughly similar to the present diversity; six extant species have been recorded by strandings and/ or sightings off the Atlantic coast of the Iberian Peninsula: Hyperoodon ampullatus, Mesoplodon bidens (Sowerby, 1804), M. densirostris, M. europaeus (Gervais, 1855), M. mirus True, 1913, and Ziphius cavirostris (see Reiner 1979; Valverde \& Galan 1996; Valverde 1997; López et al. 2002; Kiszka et al. 2007; Smith 2010). The geographic distribution of at least a part of these extant taxa being strongly related to topographic parameters (depth and slope) (Smith, 2010), we think that the concentration of large and heavy, not easily transported, fossil specimens at important depths in the proximity of local topographic features (e.g., Nazaré Canyon off Portugal or Ortegal Spur off Galicia) might reflect roughly similar ecological preferences.

Acknowledging the lack of precise stratigraphic data (see below), a comparison between the fossil ziphiid association of the Iberian Atlantic coast and those of other areas (see the systematic paragraph below) reveals that: 1) Tusciziphius atlanticus $\mathrm{n}$. sp. is also recorded in South Carolina (USA), whereas another species of Tusciziphius (T. crispus) was found in Tuscany (Italy); 2) Choneziphius is also reported in South Carolina and in the North Sea (Belgium and The Netherlands), with a few large indeterminate specimens (roughly similar to C. leidyi n. sp.) and smaller specimens (referred to C. planirostris in the North Sea); and 3) Caviziphius and Ziphirostum are recorded in the area of Antwerp (Belgium). The fossil record of Globicetus n. gen. and Imocetus n. gen. is instead restricted for now to the Iberian Atlantic coast. Unfortunately the fossil ziphiid samples from eastern North America and Mediterranean are still too fragmentary for a comprehensive comparison between these associations. The fossil ziphiid record outside the North Atlantic Ocean and Mediterranean Sea is even more fragmentary, with two major exceptions: Peru and South Africa.

From the middle Miocene-Pliocene Pisco Formation of Peru, Messapicetus gregarius Bianucci, Lambert \& Post, 2010, Ninoziphius platyrostris 
Muizon, 1983, and Nazcacetus urbinai Lambert, Bianucci \& Post, 2009 are recorded. None of these three genera is present in the Atlantic Iberian fossil association, but Messapicetus is reported in Italy with a different species ( $M$. longirostris Bianucci, Landini \& Varola, 1992; see Bianucci et al. 1992) and is tentatively reported from Maryland, east coast of USA (Fuller \& Godfrey 2007), whereas Ninoziphius Muizon, 1983 is also recorded, based on a fragmentary specimen, from the east coast of USA (Muizon \& DeVries 1985; Morgan 1994).

The fossil ziphiid association recovered by trawling from the sea floor off the South African coast, also characterized by a low stratigraphic resolution, is very diversified, being represented by at least 11 species and 9 genera (Bianucci et al. 2007, 2008). Surprisingly, none of the taxa recorded in South Africa is listed in the Atlantic Iberian fossil association or any other North Atlantic realm assemblages, possibly evidencing an ecological and/or physical barrier between North and South Atlantic, in addition to expected temporal gaps between different communities (and between species from a same region). An analysis of the extant ziphiid community reveals substantial differences, even if less pronounced, between the beaked whales off the Iberian Peninsula and South African coasts (Ross 1984; Mead 1989b; López et al. 2002; Dalebout et al. 2003, Kiszka et al. 2007; Smith 2010). At the genus level the widely ranging Hyperoodon, Mesoplodon, and Ziphius are recorded in both areas, whereas Berardius Duvernoy, 1851 and Indopacetus Moore, 1968 are not recorded in the North Atlantic. At the species level, among the eight ziphiid species living off the South African coasts, only the widely ranging Mesoplodon densirostris, $M$. mirus and Ziphius cavirostris are also recorded off the Atlantic coast of the Iberian Peninsula.

The different modern cetacean compositions of the northern and southern hemispheres are directly related to the presence of an equatorial warm water mass, representing an efficient barrier to dispersal, but also generating vicariant speciation (e.g., in the genera Berardius and Hyperoodon, both containing antitropical spe- cies) during temporary cooling event(s) of the oceanic waters (Davies 1963; Hare et al. 2002). It is possible that most of the fossil ziphiids of Iberia and South Africa were restricted to cold and/or temperate waters and consequently were not able to cross the warm equatorial barrier, as today for species of Berardius and Hyperoodon.

\section{GEOLOGICAL SETTING AND AGE OF THE SPECIMENS}

On the Ortegal Spur, off the northwestern corner of the Iberian Peninsula, one of the areas where fossil ziphiids were found (Fig. 1), the Neogene sedimentary succession lies above about $1200 \mathrm{~m}$ of Late Jurassic-Eocene deposits and is represented by Oligo-Miocene silty marl and foraminiferal ooze, associated with slope breccias or conglomerates, indicating a relatively deep-water depositional environment (Wallrabe-Adams et al. 2005; Jané et al. 2010). It is probable that the fossil ziphiids originate from one or more phosphorite episodes within this succession (see below). The Miocene sediments are irregularly covered by Plio-Quaternary deposits consisting of alternated silt and clay laminas interbedded with coarse sediments (Jané et al. 2010).

The Nazare Canyon, in the area where the fossil ziphiids from Portugal were found, represents one of the late Variscan faults that cut transversally the Mesozoic rifted Iberian margin (Pinheiro et al. 1996). At the end of Mesozoic the rifting ended; during Eocene and Miocene this area suffered a compressional episode that reactivated the old Variscan structures (Pinheiro et al. 1996). Published studies on the sediments outcropping on the sea bottom of the Nazaré Canyon report that a large portion is covered with Holocene mud (Koho et al. 2007; Masson et al. 2011). The age of rocks of the area where the fossil ziphiids were found include Miocene and Pliocene (Badagola 2008; LNEG-LGM 2001). According to the geological map of the continental platform, the only Miocene rocks that might have been the source of the skulls here described are in an area around $39^{\circ} 18^{\prime} \mathrm{N}$ and $9^{\circ} 47^{\prime} \mathrm{W}$ and about $160 \mathrm{~m}$ of depth, in the Mar da Ericeira, which has 
been dated as Aquitanian to Langhian, early to middle Miocene (Badagola 2008).

Although we have not found data about the presence of phosphorite levels in the specific areas where the fossil ziphiids were collected, North Atlantic phosphorite deposits dated to Cenozoic are reported both off Spain and Portugal (Riggs \& Sheldon 1990). These sediments are related to the Upper Early Miocene-Middle Miocene (20-14 Ma) episode of phosphogenesis associated with the TB2 second-order eustatic sea-level fluctuation (Haq et al. 1987; Riggs \& Sheldon 1990). This interval of age is compatible with those of the fossil ziphiids examined, considering that the oldest unquestionable records of this family are from late early Miocene-middle Miocene (Bianucci et al. 2005; Lambert \& Louwye 2006). Unfortunately precise ages are not available for most of the fossil ziphiids from other localities in the world that are related to those examined here. Indeed, most of these fossil ziphiids are from phosphorite deposits and/or their precise stratigraphical position is unknown. Moreover, since only one Iberian species (Tusciziphius atlanticus n. sp.) is also reported from a locality outside Iberia, faunal correlations remain difficult. As mentioned above, T. atlanticus n. sp. was found reworked on the bottom of Morgan River (South Carolina, USA), and a late Miocene-Pliocene age can only be proposed (Post et al. 2008). Tusciziphius is also recorded from Italy, with a more precise early Pliocene age (Bianucci 1997; Bianucci et al. 2001), but with a different species (T. crispus). A precise dating is not available for most of the Neogene ziphiids of the North Sea (Belgium and the Netherlands) (Bianucci \& Post 2005; Lambert 2005; Lambert \& Louwye 2006). This is unfortunately especially true for genera also reported (Choneziphius), or tentatively reported (Caviziphius and Ziphirostrum), from Iberian Peninsula. Nevertheless Lambert (2005) mentioned a skull of Ziphirostrum marginatum and a skull of Choneziphius planirostris, both collected from the Tortonian (late Miocene) Deurne Sands Member of the Diest Formation (Antwerp, Belgium). The genus Choneziphius is also reported from Phosphate Beds of South Car- olina, USA, and from reworked sediments of the Lee Creek Mine, North Carolina (Whitmore \& Kaltenbach 2008), with fragmentary skulls that, based on their large size, could be conspecific with C. leidyi n. sp. Interestingly, even if the age of these Northern American ziphiids is not well defined (see Post et al. 2008), Riggs \& Sheldon (1990: table 18.1) refer the South and North Carolina phosphorites to the same episode (TB2) than the Iberian phosphorites. In conclusion, the comparison with fossil ziphiids from other localities only provides minor clues for the definition of the age of the phosphoritized Iberian ziphiids. A late early Miocene-middle Miocene age, as suggested by TB2 phosphorites, is probable, even if the few well-dated extra-Iberian ziphiids (belonging to different species) are younger (late Miocene or early Pliocene). However, we cannot exclude a priori that all or part of these fossil ziphiids were collected from younger phosphorite episodes (e.g., the TB3, Late Miocene-Pliocene), for now not documented from the sea floor off the Atlantic coasts of Spain and Portugal. New data on the local geology and stratigraphy and the dating of associated phosphorites through radiometric methods are needed to better define the very approximative ages provided here for these specimens. Such additional data would be crucial to further support the palaeobiogeographic and palaeoecological hypotheses discussed above (see Pyenson et al. 2009 for an example of the importance of a detailed sedimentological and stratigraphical analysis for the understanding of fossil marine mammal localities).

\section{CONCLUSION}

The systematic study of 40 partial fossil ziphiid skulls dredged from the Atlantic Ocean floor off Portugal and Spain lead to the description of two new genera, Globicetus n. gen. and Imocetus n. gen., and four new species, G. hiberus n. gen., n. sp., I. piscatus n. gen., n. sp., Choneziphius leidyi n. sp., and Tusciziphius atlanticus n. sp. In addition, members of the genera Caviziphius and Ziphirostrum are tentatively reported. 
The phylogenetic analysis of the new taxa places them in the subfamily Ziphiinae here redefined, also including Choneziphius planirostris, Tusciziphius crispus, and the genera Izikoziphius and Ziphius.

Bizarre elements observed on the skull of Globicetus $\mathrm{n}$. gen. (large premaxillary spheroid) and T. atlanticus $\mathrm{n}$. sp. (medial premaxillary bulge, likely sexually dimorphic), are commented from a functional point of view; these structures are confronted to various hypotheses proposed for the function of pachyosteosclerotic parts of the rostrum in several ziphiid lineages.

Other peculiar features of the skull of Imocetus (spur-like rostral maxillary crests and long maxillary crests limiting a large facial basin) and Choneziphius spp. (excrescences on the maxilla at the rostrum base) are interpreted as areas of origin for rostral and facial muscles.

The palaeobiogeography of Neogene ziphiids is discussed in the light of the new discoveries. Differences in the composition of cold to temperate northern and southern hemisphere ziphiid communities might be explained by a warm equatorial barrier.

Finally, by comparison with other fossil ziphiid assemblages in the world and on the basis of a few geological and stratigraphic data for the Atlantic Ocean floor off Portugal and Spain, a late early to middle Miocene age is very tentatively proposed for the studied specimens. However, this hypothesis should be considered cautiously; a younger age cannot be excluded for part or all of these specimens.

\section{Acknowledgements}

We would like to thank the following fishermen who donated specimens to SGHN: Miguel Ángel Iglesias and the crew of the ship Nuevo Richard from Cedeira; José Castro Sambás and his son Daniel from Muxía; Luis from Camelle; José Antonio González and Lino from Cedeira; the crew of the ship Gonzacove Uno; Manuel Ángel Iglesias from Cedeira. Thanks are also due to Carlos Filipe Alexandre, Estevão Anastácio da Cruz, Francisco Reiner, Ildo Hermógenes Marques da Silva, José Augusto, Luciano Mesquita, and Mário Estevens who donated the Portuguese specimens to the ML or provided informations about the locations, and to Remmert Schouten and Pedro Viegas for calling our attention to Portuguese specimens. We also thank for access to the collections under their care the following persons and/or institutions: P. Agnelli (Museo di Zoologia, Università di Firenze), CEMMA (Coordinadora para o Estudio dos Mamíferos Mariños, Galicia), E. Cioppi and S. Dominici (IGF), F. J. Cristobo (IEO), J. I. Díaz (SGHN), X. Guerra and I. Fraga (MHNUSC), G. Lenglet (Institut royal des Sciences naturelles de Belgique, Brussels), J. R. García and Lucía (Museo Marítimo de Asturias in Luanco), J. G. Mead and C. W. Potter (United States National Museum of Natural History, Smithsonian Institution, Washington DC), S. van de Mije, H. van Grouw, and R. van Zelst (Nationaal Natuurhistorisch Museum Naturalis, Leiden), and H. van der Es (NMR). Finally we wish to thank the reviewers C. de Muizon (Muséum national d'Histoire naturelle, Département Histoire de la Terre, Paris), and N. D. Pyenson (United States National Museum of Natural History, Smithsonian Institution, Washington DC) for their constructive comments that greatly improved the manuscript, as well as the editors D. Merle and A. Ohler for nomenclature points.

\section{REFERENCES}

ABEL O. 1905. - Les odontocètes du Boldérien (Miocène supérieur) des environs d'Anvers. Mémoires du Musée royal d'Histoire naturelle de Belgique 3: 1-155.

Au W. W. L. 1993. - The Sonar of Dolphins. Springer Verlag, New York, 277 p.

BADAGOLA A. P. L. 2008. - Evolução morfo-tectónica da plataforma continental do Esporão da Estremadura. Tese de mestrado, Geologia Dinâmica (Geodinâmica). Faculdade de Ciências, Universidade de Lisboa, available at http://repositorio.ul.pt/handle/10451/1308

BiANUCCI G. 1997. - The Odontoceti (Mammalia Cetacea) from Italian Pliocene. The Ziphiidae. Palaeontographia Italica 84: 163-192.

BianuCCI G. \& POST K. 2005. - Caviziphius altirostris, a new beaked whale from the Miocene southern North Sea basin. Deinsea 11: 1-6.

BianuCCi G., LANDini W. \& VArOla A. 1992. - Messapicetus longirostris, a new genus and species of Ziphiidae (Cetacea) from the late Miocene of "Pietra Leccese" (Apulia, Italy). Bolletino della Società Paleontologica Italiana 31: 261-264. 
Bianucci G., LANDini W. \& Varola A. 1994. Relationships of Messapicetus longirostris (Cetacea, Ziphiidae) from the Miocene of South Italy. Bollettino della Società Paleontologica Italiana 33 (2): 231-241.

Bianucci G., Mazza P., Merola D., Sarti G. \& Cascella A. 2001 - The Early Pliocene mammal assemblage of Val di Pugna (Tuscany, Italy) in the light of calcareous plankton biostratigraphical data and paleoecological observations. Rivista Italiana di Paleontologica e Stratigrafia 107 (3): 425-438.

Bianucci G., Landini W., Valleri G., Ragaini L. \& VArola A. 2005. - First cetacean fossil records from Ecuador, collected from the Miocene of Esmeraldas Province. Rivista Italiana di Paleontologia e Stratigrafia 111 (2): 345-350.

Bianucci G., Lambert O. \& Post K. 2007. - A high diversity in fossil beaked whales (Odontoceti, Ziphiidae) recovered by trawling from the sea floor off South Africa. Geodiversitas 29 (4): 561-618.

Bianucci G., Post K. \& Lambert O. 2008. — Beaked whale mysteries revealed by sea floor fossils trawled off South Africa. South African Journal of Science 104 (3-4): 140-142.

Bianucci G., Lambert O. \& Post K. 2010. — High concentration of long-snouted beaked whales (genus Messapicetus) from the Miocene of Peru. Palaeontology 53 (5): 1077-1098.

BRISSON M.-J. 1762. - Regnum Animale in classes IX distributum, sine synopsis methodica. Theodorum Haak, Paris, 296 p.

BufFRÉNIL V. DE \& CASINOS A. 1995. - Observations histologiques sur le rostre de Mesoplodon densirostris (Mammalia, Cetacea, Ziphiidae) : le tissu osseux le plus dense connu. Annales de Sciences Naturelles, 13e série, 16: 21-32.

Buffrénil V. DE \& Lambert O. 2011. - Histology and growth pattern of the pachy-osteosclerotic premaxillae of the fossil beaked whale Aporotus recurvirostris (Mammalia, Cetacea, Odontoceti). Geobios 44: 45-56.

Buffrénil V. DE, Zylberberg L., Traub W. \& CAsinos A. 2000. - Structural and mechanical characteristics of the hyperdense bone of the rostrum of Mesoplodon densirostris (Cetacea, Ziphiidae): summary of recent observations. Historical Biology 14: 57-65.

Covelo P. \& Martínez J. 2001 - Varamientos de mamíferos marinos en las costas de España y Portugal entre 1996 y 1998: Atlancetus. Galemys 13: 93-106.

CrAnford T. W. 1999. - The sperm whale's nose: sexual selection on a grand scale? Marine Mammal Science 15 (4): 1133-1157.

Cranford T. W., Amundin M. \& Norris K. S. 1996. - Functional morphology and homology in the Odontocete nasal complex: implications for sound generation. Journal of Morphology 228: 223-285.
Cranford T. W., MacKenna M. F., Soldevilla M. S., Wiggins S. M., Goldbogen J. A., SHadwick R. E., Krysl P., St. Leger J. A. \& Hildebrand J. A. 2008. - Anatomic geometry of sound transmission and reception in Cuvier's beaked whale (Ziphius cavirostris). The Anatomical Record 291 (4): 353-378.

CUVIER G. 1823. - Recherches sur les ossements fossiles, 5 (1ère partie). G. Dufour et E. D'Ocagne, Paris, $405 \mathrm{p}$.

Dalebout M. L., Mead J. G., Baker C. S., Baker A. N. \& VAN Helden A. L. 2002. - A new species of beaked whale Mesoplodon perrini sp. n. (Cetacea: Ziphiidae) discovered through phylogenetic analyses of mitochondrial DNA sequences. Marine Mammal Science 18 (3): 577-608.

Dalebout M. L., Ross G. J. B., Baker C. S., Anderson R. C., Best P. B., COCKCROft V. G., Hinsz H. L., Peddemors V. \& Pitman R. L. 2003. - Appearance, distribution, and genetic distinctiveness of Longman's beaked whale, Indopacetus pacificus. Marine Mammal Science 19 (3): 421-461.

DAVIES J. L. 1963. - The antitropical factor in cetacean speciation. Evolution 17 (1): 107-116.

Du Bus B. A. L. 1868. - Sur différents Ziphiides nouveaux du Crag d'Anvers. Bulletin de l'Académie Royale des Sciences de Belgique 25: 621-630.

Du Bus B. A. L. 1872. - Mammifères nouveaux du Crag d'Anvers. Bulletin de l'Académie royale des Sciences de Belgique 34: 491-509.

Duvernoy G. 1851. - Mémoire sur les caractères ostéologiques des genres nouveaux ou des espèces nouvelles de cétacés vivants ou fossiles. Annales de Sciences naturelles, Zoology 15: 52-68.

Estevens M. \& Ávila S. P. 2007. - Fossil whales from the Azores. Açoreana. Revista de Estudos Açoreanos 5: 140-161.

Flower W. H. 1867. - Description of the skeleton of Inia geoffrensis and the skull of Pontoporia blainvillii, with remarks on the systematic position of these animals in the Order Cetacea. Transactions of the Zoological Society of London 6: 87-116.

Fordyce R. E. \& Cullen D. J. 1979. - A Miocene ziphiid whale (Odontoceti: Cetacea) from Central Chatham Rise, East of New Zealand. New Zealand Oceanographic Institute Records 4 (6): 45-53.

Fuller A. J. \& Godfrey S. J. 2007. — A late Miocene ziphiid (Messapicetus sp.: Odontoceti: Cetacea) from the St. Marys Formation of Calvert Cliffs, Maryland. Journal of Vertebrate Paleontology 27: 535-540.

Goloboff P. 1993. - Estimating character weights during tree search. Cladistics 9: 83-91.

Gowans S. \& Rendell L. 1999. - Head-butting in northern bottlenose whales (Hyperoodon ampullatus): a possible function for big heads? Marine Mammal Science 15 (4): 1342-1350. 
GraY J. E. 1821. - On the natural arrangement of vertebrose animals. The London Medical Repository 15: 296-310.

GraY J. E. 1850. - Catalogue of the Specimens of Mammalia in the Collections of the British Museum. Part I-Cetacea. Richard and John E. Taylor, London, 153 p.

HaQ B. U., Hardenbol J. \& Vail P. R. 1987. — Chronology of fluctuating sea levels since the Triassic. Science 235: 1156-1166.

Hardy M. T. 2005. - Extent, development and function of sexual dimorphisms in the skulls of the Bottlenose whales (Hyperoodon spp.) and Cuvier's beaked whale (Ziphius cavirostris). Master thesis, School of Biological Sciences, University of Wales, Bangor, UK, 99 p.

Hare M. P., Cipriano F. \& Palumbi S. R. 2002. Genetic evidence on the demography of speciation in allopatric dolphin species. Evolution 56 (4): 804-816.

HeYNING J. E. 1984. - Functional morphology involved in intraspecific fighting of the beaked whale, Mesoplodon carlhubbsi. Canadian Journal of Zoology 62: 1645-1654.

HEYNING J. E. 1989a. - Comparative facial anatomy of beaked whales (Ziphiidae) and a systematic revision among the families of extant Odontoceti. Contributions in Science, Natural History Museum of Los Angeles County 405:1-64.

HEYNING J. E. 1989b. - Cuvier's beaked whale Ziphius cavirostris G. Cuvier, 1823, in RIDGWAY S. H. \& HARRISON R. (eds), Handbook of Marine Mammals, vol. 4: River Dolphins and the Larger Toothed Whales. Academic Press, London: 289-308.

HorikaWa H., TAZAKI K. \& Kanno T. 1987. — [Fossil Ziphiidae from Koshiji-Syo off Sado Island, Central Japan]. Bulletin of the Sado Museum 9: 225-230 (in Japanese).

Huggenberger S., Rauschman M. A., Vogl T. J. \& OELSCHLÄGER H. A., 2009. - Functional morphology of the nasal complex in the harbor porpoise (Phocoena phocoena L.). The Anatomical Record 292: 902-920.

Jané G., Maestro A., Ercilla G., López-Martínez J., De Andrés J. R., Casas D., González- Aller D. \& CATALÁN-MOROLLÓN M. 2010. - Occurrence of pockmarks on the Ortegal Spur continental margin, Northwestern Iberian Peninsula. Marine and Petroleum Geology 27: 1551-1564.

Kiszka J., Macleod K., Van Canneyt O., WalKER D. \& RIDOUX V. 2007. - Distribution, encounter rates, and habitat characteristics of toothed cetaceans in the Bay of Biscay and adjacent waters from platfrom-of-opportunity data. ICES Journal of Marine Science 64 (5): 1033-1043.

Koho K. A., Kouwenhoven T. J., De Stigter H. C. \& VAN DER ZWAAN G. J. 2007. - Benthic foraminifera in the Nazaré canyon, Portuguese continental margin: influence of sedimentary disturbance on fauna. Marine Micropaleontology 66: 27-51.

LAMBERT O. 2005. - Systematics and phylogeny of the fossil beaked whales Ziphirostrum du Bus, 1868 and Choneziphius Duvernoy, 1851 (Cetacea, Odontoceti), from the Neogene of Antwerp (North of Belgium). Geodiversitas 27 (3): 443-497.

LAMBERT O. \& LOUWYe S. 2006. - Archaeoziphius microglenoideus, a new primitive beaked whale (Mammalia, Cetacea, Odontoceti) from the Middle Miocene of Belgium. Journal of Vertebrate Paleontology 26: 182-191.

Lambert O., Bianucci G. \& Post K. 2009. - A new beaked whale (Odontoceti, Ziphiidae) from the middle Miocene of Peru. Journal of Vertebrate Paleontology 29 (3): 911-922.

Lambert O., Bianucci G. \& Post K. 2010. Tusk-bearing beaked whales from the Miocene of Peru: sexual dimorphism in fossil ziphiids? Journal of Mammalogy 91 (1): 19-26.

Lambert O., Buffrénil V. de \& Muizon C. DE 2011. - Rostral densification in beaked whales: diverse processes for a similar pattern. Comptes Rendus Palevol 10: 453-468.

LANKESTER E. R. 1870. - A new ziphioid cetacean from the Suffolk Bone-bed (Choneziphius packardi). Quarterly journal of the Geological Society of London 26: 502-507.

LEIDY J. 1876. - Remarks on fossils from the Ashley Phosphate Beds. Proceedings of the Academy of Natural Sciences of Philadelphia 1876: 80-81; 86-87.

LEIDY J. 1877. - Description of vertebrate remains, chiefly from the Phosphate Beds of South Carolina. Journal of the Academy of Natural Sciences of Philadelphia, 2nd series 8: 209-261.

LNEG-LGM 2001. - Carta Geológica de Portugal à escala 1:1.000.000 [Geological map]. Lisboa. ISBN: 978-989-675-005-3.

lópez A., Santos M. B., Pierce G. J., González A. F., Valeiras X. \& Guerra A. 2002. — Trends in strandings and by-catch of marine mammals in northwest Spain during the 1990s. Journal of the marine Biological Association of the U.K. 82: 1-9.

MACLEOD C. D. 2002. - Possible functions of the ultradense bone in the rostrum of Blainville's beaked whale (Mesoplodon densirostris). Canadian Journal of Zoology 80: 178-184.

MacLeod C. D. \& Herman J. S. 2004. - Development of tusks and associated structures in $\mathrm{Me}$ soplodon bidens (Cetacea, Mammalia). Mammalia 68: 175-184.

Masson D. G., Huvenne V. A. I., De Stigter H. C., Wolff G. A., Kiriakoulakis K., Arzola R. G. \& BlackBiRD S. 2010. - Efficient burial of carbon in a submarine canyon. Geology 38: 831-834.

MeAD J. G. 1975. - Anatomy of the external nasal 
passages and facial complex in the Delphinidae (Mammalia : Cetacea). Smithsonian Contribution to Zoology 207: 1-67.

MEAD J. G. 1989a. - Bottlenose whales Hyperoodon ampullatus (Forster, 1770) and Hyperoodon planifrons Flower, 1882, in RIDGWAY S. H. \& HARRISON R. (eds), Handbook of Marine Mammals, vol. 4: River Dolphins and the Larger Toothed Whales. Academic Press, London: 321-348.

MEAD J. G. 1989b. - Beaked whales of the genus Mesoplodon, in RIDGWAY S. H. \& HARRISON R. (eds), Handbook of Marine Mammals, vol. 4: River Dolphins and the Larger Toothed Whales. Academic Press, London: 349-430.

MeAd J. G. \& FordyCE R. E. 2009. - The therian skull: a lexicon with emphasis on the odontocetes. Smithsonian Contributions to Zoology 627: 1-248.

MijÁN I. 2007. - Hallazgos de restos fósiles de $H y$ peroodon sp. (Cetacea, Ziphiidae) en las costas gallegas (NO España). Revista de Biología Marina y Oceanografía 42 (3): 253-260.

MiYaZaKi N. \& HasegaWA Y. 1992. - A new species of fossil beaked whale, Mesoplodon tumidirostris sp. nov. (Cetacea, Ziphiidae) from the Central North Pacific. Bulletin of the National Science Museum, Tokyo, Ser. A 18 (4): 167-174.

Morgan G. S. 1994. - Miocene and Pliocene marine mammal faunas from the Bone Valley Formation of Central Florida, in BERTA A. \& Demeré T. A. (eds), Contributions in marine mammal paleontology honoring Frank C. Whitmore, Jr. Proceedings of the San Diego Society of Natural History 29: 239-268.

Muizon C. DE. 1984. - Les Vertébrés de la Formation Pisco (Pérou). Deuxième partie: les Odontocètes (Cetacea, Mammalia) du Pliocène inférieur du Sud-Sacaco. Travaux de l'Institut français d'Études andines 27: 1-188.

Muizon C. DE \& DeVRies T. J. 1985. — Geology and paleontology of late Cenozoic marine deposits in the Sacaco area (Peru). Geologische Rundschau 74: 547-563.

Pinheiro L. H., Wilson R. C. L., Pena Dos Reis R., Whitmarsh R. B. \& Ribeiro A. 1996. - The Western Iberia Margin: a Geophysical and Geological Overview, in Whitmarsh R. B., SAWyer D. S., Klaus A. \& Masson D. G. (eds), Proceedings of the Ocean Drilling Program, Scientific Results 149: 3-23.

Post K., Lambert O. \& Bianucci G. 2008. - First record of Tusciziphius crispus (Cetacea, Ziphiidae) from the Neogene of the US east coast. Deinsea 12: 1-10.

Pyenson N. D., Irmis R. B., Lipps J. H., Barnes L. G., Mitchell E. D. JR. \& MacLeod S. A. 2009. Origin of a widespread marine bonebed deposited during the middle Miocene Climatic Optimum. Geology 37 (6): 519-522.
REINER F. 1979. - Nota sobre un raro ziphioid, $M e$ soplodon densirostris, Blainville 1817, nas costas de Portugal. Museo Marino Cascais, Memorios Series Zoologie 1: 1-12.

Riggs S. R. \& SHELdon R. P. 1990. - Paleoceanographic and paleoclimatic controls of the temporal and geographic distribution of upper Cenozoic continental margin phosphorites, in BURNETT W. C. \& Riggs S. R. (eds), Phosphate deposits of the world. Volume 3: Neogene to modern phosphorites. Cambridge University Press, Cambridge: 207-222.

Robineau D. 1973. - Sur deux rostres de Mesoplodon (Cetacea, Hyperoodontinae). Mammalia 37 (3): 504-513.

Ross G. J. B. 1984. - The smaller cetaceans of the south east coast of southern Africa. Annals of the Cape Provincial Museums of Natural History 15 (2): 173-410.

SCHENKKAN E. J. 1973. - On the comparative anatomy and function of the nasal tract in odontocetes (Mammalia, Cetacea). Bijdragen tot de Dierkunde 43: 127-159.

SMITH J. 2010. - The ecology of Cuvier's Beaked Whale, Ziphius cavirostris (Cetacea: Ziphiidae), in the Bay of Biscay. Unpublished PhD thesis, Graduate School of the National Oceanography Centre, Southampton, $214 \mathrm{p}$.

SWOFFord D. L. 2001. - PAUP*. Phylogenetic Analysis Using Parsimony (*and other methods). Version 4b10. Sinauer Associates, Sunderland, Massachusetts (software).

Tazaki K., Horikawa H. \& Miyazaki S. 1987. [Fossil Ziphiidae from Hyotan-Guri off Sado Island, Central Japan]. Bulletin of the Sado Museum 9: 219-223 (in Japanese).

Tyler P., Amaro T., Arzola R., Cunha M. R., De Stigter H., GoOdAy A., HuvenNe V., IngelS J., KirIAKOUlaKis K., Lastras G., Masson D., Oliveira A., Pattenden A., Vanreusel A., Van Weering T., Vitorino J., WITTE U. \& WOLFF G. 2009. — Europe's grand canyon: Nazaré submarine canyon. Oceanography 22 (1): 46-57.

Valverde J. A. 1997. - Notes on a specimen of Blainville's beaked whale Mesoplodon densirostris (De Blainville, 1817) stranded on the coast of Donana, Huelva, southern Spain. European Research on Cetaceans 10: 184-189.

Valverde J. A. \& Galan J. M. 1996. - Notes on a specimen of Gervais' beaked whale Mesoplodon europaeus (Gervais), Ziphiidae stranded in Andalucia, Southern Spain. European Research on Cetaceans 10: 177-183.

Wallrabe-Adams H. J., Altenbach A. V., Kempe A., KUHNT W. \& SCHÄFER P. 2005. - Facies development of ODP Leg 173 sediments and comparison with tectono-sedimentary sequences of compressional Iberian plate margins - a general overview. Journal of Iberian Geology 31 (2): 235-251. 
Whitmore F. C. JR. \& Kaltenbach J. A. 2008. Neogene Cetacea of the Lee Creek Phosphate Mine, North Carolina. Virginia Museum of Natural History Special Publication 14: 181-269.

Whitmore F. C. JR., Morejohn G. V. \& Mullins, H. T. 1986. - Fossil beaked whales - Mesoplodon longirostris dredged from the ocean bottom. National Geographic Research 2 (1): 47-56.
ZвYsZEWski G. 1954. - Découverte d'une mandibule de Palaeoziphius dans le Miocène de Melides. Comunicaçôes dos Serviços Geológicos de Portugal 35: 51-55.

Zioupos P., Currey J. D., Casinos A. \& BuffréNIL V. DE 1997. - Mechanical properties of the rostrum of the whale Mesoplodon densirostris, a remarkably dense bony tissue. Journal of Zoology 241 (4): 725-737.

Submitted on 8 June 2011; accepted on 28 October 2011; published on 29 March 2013. 


\section{APPENDIX 1}

Coding of the characters for taxa not considered in the previous analysis (Bianucci et al. 2010). 0, primitive state; 1, 2, 3, derived states; a, variable between 0 and 1 ; ?, missing character.

$122344556 \quad 7 \quad 8 \quad 91011121314151617181920212223242526272829$

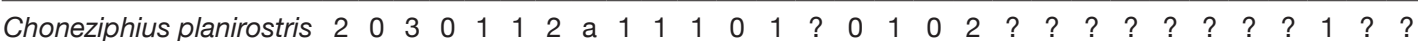

Choneziphius leidyi

$\begin{array}{lllllllllllllllllllllllllllll}1 & 0 & 3 & 0 & 1 & 1 & 3 & 0 & 1 & 1 & 1 & 0 & 1 & ? & 0 & 1 & 0 & 2 & ? & ? & ? & ? & ? & ? & ? & ? & 1 & ? & \text { ? }\end{array}$

Tusciziphius crispus

$\begin{array}{lllllllllllllllllllllllllllll} & 0 & 3 & 0 & 1 & 0 & 3 & 2 & ? & 1 & 1 & 0 & 2 & 1 & 0 & 0 & 0 & 2 & 1 & ? & ? & ? & ? & ? & \text { ? } & \text { ? } & 1 & \text { ? } & \text { ? }\end{array}$

Tusciziphius atlanticus

$\begin{array}{lllllllllllllllllllllllllllll}1 & 0 & 3 & 0 & 1 & 0 & 3 & 2 & ? & 1 & 1 & 0 & 2 & 1 & 0 & 0 & 0 & 2 & 1 & ? & ? & \text { ? } & \text { ? } & \text { ? } & \text { ? } & \text { ? } & 1 & \text { ? } & \text { ? }\end{array}$

Globicetus

$\begin{array}{llllllllllllllllllllllllllllll}1 & 0 & 3 & 0 & 1 & 0 & 3 & 2 & ? & 3 & 1 & 1 & 2 & 1 & 0 & 0 & 0 & 2 & ? & ? & ? & ? & ? & ? & ? & ? & 1 & \text { ? } & \text { ? }\end{array}$

Imocetus

$\begin{array}{lllllllllllllllllllllllllllll}2 & 0 & 3 & 1 & 0 & 0 & 3 & 2 & \text { ? } & 3 & 1 & 0 & 1 & 1 & \text { ? } & 0 & 0 & 2 & \text { ? } & \text { ? } & \text { ? } & \text { ? } & \text { ? } & \text { ? } & \text { ? } & \text { ? } & 1 & \text { ? } & \text { ? }\end{array}$

